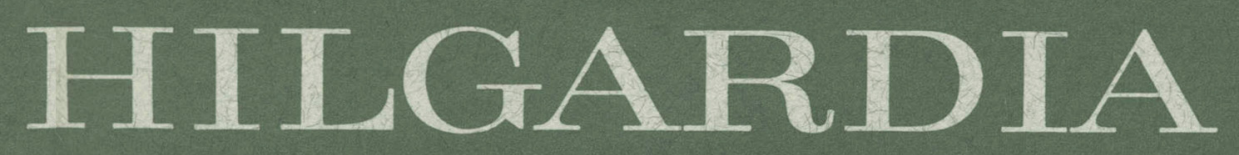

A JOURNAL OF AGRICULTURAL SCIENCE PUBLISHED BY THE CALIFORNIA AGRICULTURAL EXPERIMENT STATION

Volume 34, Number $7 \cdot$ April, 1963

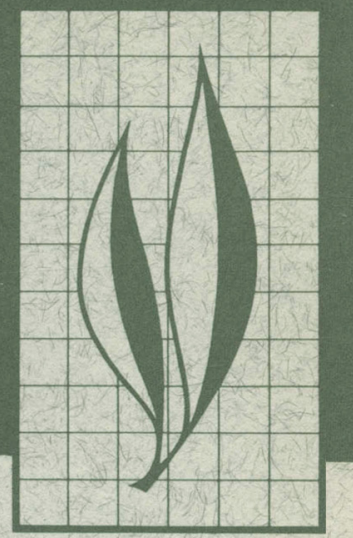

\title{
Phytoseiid Mites of California
}

\author{
Robert O. Schuster \\ and \\ A. Earl Pritchard
}




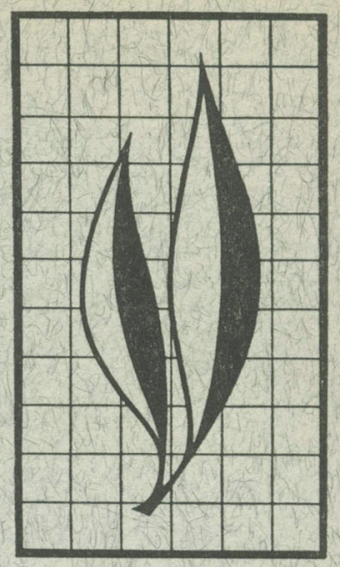

Phytoseiid mites are beneficial to agriculture because they often prey upon phytophagous mites. This publication provides keys, descriptions, and illustrations for the recognition of 52 California species of phytoseiids and hitherto unpublished data on their distribution and habitats. It gives general information on collecting and preparation of specimens.

The following new species are described:

TYPHLODROMINI-Metaseiulus pinnatus, M. pomoides.

AMBLYSEIINI-Amblyseius lecanis, A. cborites, A. ablusus, $A$.

lindquisti, A. inornatus, A. loxus, A. kennetti, A. vallis, $A$. mckenziei, A. buffakeri, A. scyphus, A. tabis.

\section{THE AUTHORS:}

Robert O. Schuster is Laboratory Technician II in Entomology and Parasitology, Davis; A. Earl Pritchard was formerly Associate Professor of Entomology and Associate Entomologist in the Experiment Station, Berkeley. 


\section{Phytoseiid Mites of California ${ }^{1}$}

Phytoseild mites are receiving increasing attention because of their role as predators of phytophagous mites, particularly tetranychids and eriophyids. Crop losses due to phytophagous mites have diminished in California in recent years, mainly because of the application of organic acaricides. Probably, however, part of the mite control may be attributed to predation by phytoseiids.

In the present paper, our primary concern is the classification of the phytoseiids in the University of California collections at Berkeley and at Davis. We have not used all data from earlier works or consistently included records for California specimens we have not seen. We have enough data on the California distribution and habitats of some species to warrant assumptions as to whether or not they may be endemic and may have value for the control of phytophagous mites on agricultural crops.

There exist few records for California of phytoseiids collected before 1930 , and little attention was paid to the activities of these mites before 1945. At present it is difficult to assess their relative effectiveness, but we assume that endemic species have become adapted to present cultural conditions in California and that introduced species may assume economic significance.

In California, little effort has been directed toward establishing programs that eliminate phytophagous mites without detriment to predator popula- tions. A 99 per cent control of phytophagous mites, possible with present acaricides, may nearly eliminate the predator population by starvation as well as by direct poisoning. Though infrequently, we have observed economic control of phytophagous mites by predaceous mites in California orchards and vineyards. Examples of inadequate control have been more numerous.

Of the papers dealing with ecology and biological control, the most significant for California agriculture is that of Huffaker and Kennett (1956). Their study indicates that the release of either Amblyseius cucumeris (Oudemans) or A. aurescens Athias-Henriot in strawberry plantings infested with cyclamen mite can result in permanent establishment of these predators. Smith and Summers (1949) observed in Santa Cruz County that Phytoseiulus macropilis (Banks) controlled the two-spotted spider mite on strawberries for a short period and then virtually disappeared, although the spider mites remained. Other predaceous mites-for example, Amblyseius floridanus (Muma) - are widespread in California and are abundant but restricted to soil and litter habitats.

Although some phytoseiids can utilize pollen or honeydew as food (Chant, $1960 a$ ), the large populations of predaceous mites are almost always associated with an abundant food supply of other mites. Two exceptions are overwintering and aestivating populations.

\footnotetext{
${ }^{1}$ Submitted for publication November 1, 1961.
} 
We suggest the possibility of aestivation because of occasional summer recoveries from soil of large numbers of mature but nongravid Amblyseius palustris (Chant). In England, Chant (1960a) recovered only two specimens of phytoseiids from 300 soil samples, but workers in California have recovered many species and large numbers of individuals by Berlese-funnel extraction from soil and litter samples.

Collection and Preparation. There are several ways to obtain specimens of phytoseiid mites. The most informative but most tedious way is to remove them by hand, under a dissecting microscope, from a sample of field material. A greater number of specimens may be obtained by processing the sample of vegetation, litter, or soil in a Berlese funnel.

The forms of Berlese funnels are as numerous as the interests of collectors and the variety of materials available for construction. One type, approximately as described by Newell (1955), is excellent for general collecting. The appendix gives details for its construction. A 16-inch-square funnel is easily portable and is large enough to process a cubic foot of litter or a large sample of bark, leaves, or other plant material.

Samples of soil or vegetation, as collected in canvas, plastic, or multilayered paper bags, may be stored in a cool place $\left(5^{\circ}\right.$ to $15^{\circ} \mathrm{C}$ ) for a week or more. Drying in storage, if not extreme, may aid the extraction of specimens. The steps in processing are:

1) Place a dry container under the funnel.

2) Fit a piece of window screen in the bottom of the hopper, and-for samples of very fine particle size-a double layer of cheesecloth above the screen.

3) Empty the sample into the hopper and return detritus caught in the dry container to the sample in the hopper. 4) Attach a specimen bottle, usually containing 95 per cent ethyl alcohol, under the funnel.

5) Close the lid and apply moderate heat. A 100-watt heat source will bring an average sample to approximately $45^{\circ} \mathrm{C}$ in eight hours, and more than 90 per cent of the phytoseiids or other arthropods will leave the sample within this period.

6) Remove the specimen bottle before emptying the hopper.

7) Clean hopper, grid, and funnel thoroughly before processing another sample.

The specimens from the bottle are usually sorted in a petri dish under a low-power dissecting microscope. A flattened insect pin held in a pin vise makes a good spatula for manipulating specimens. Specimens can be stored for prolonged periods in 95 per cent ethyl alcohol in shell vials. If the vial is full and a cotton stopper is wet in alcohol before plugging, no air will be present in the vial. Individual vials, cotton-end down, can be stored in pint jars. The cotton stopper does not deteriorate as would cork or synthetic rubber, and the only further requirement is to maintain the alcohol level in the larger jar.

Phytoseiids are usually mounted in a modified Berlese fluid. We obtain the best results with the following formula:

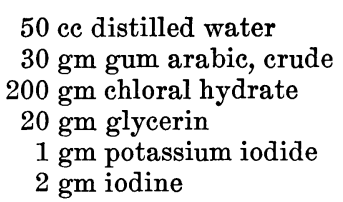

Completely dissolve gum arabic in water, allowing about four hours at $50^{\circ} \mathrm{C}$. Add chloral hydrate while the mixture is still warm. When this is dissolved, stir in the glycerin, then the potassium iodide. Filter through several layers of cheesecloth or through paper in a Büchner funnel. Last, add iodine crystals.

Any mite-living or dead, desiccated or from any liquid-can be mounted in this medium. Mounts are only semipermanent, but for critical study they are superior to mounts in any other medium. The usual position is dorsal surface up. After applying the cover- 
glass, heat the slide over an alcohol lamp until a bubble appears. This heating hastens clearing and distends the legs and mouthparts of the specimen. Continue clearing in a slide oven or on a hot-plate for 24 hours at about $45^{\circ} \mathrm{C}$. The iodine stains the specimens and seems to decrease the crystallization frequently encountered in Berlese media.

Reasonably good permanent mounts are prepared as follows: Clear and stain the specimens for at least eight hours at $60^{\circ} \mathrm{C}$ in lacto-phenol (three parts 85 per cent lactic acid and one part phenol) containing a small amount of acid fuchsin or lignin pink. Transfer directly to absolute isopropanol for dehydration, and then clear in xylol. To overcome the tendency of soft-bodied animals to collapse when placed in balsam or other xylol-soluble mountants, place the specimen in a small drop of xylol on the slide and apply a coverglass with mounting medium on its underside.

Taxonomy. Even though few of the world genera of Phytoseiidae are included in the California fauna, it seems appropriate to give our interpretation of the relationships within this family, because students of the group disagree on concepts pertaining to generic and higher categories.

Our classification recognizes six tribes. The present paper treats two of the six in detail. Of a third tribe, only one species is known in California. The division of tribes into genera is based on patterns of dorsal chaetotaxy, diagrammed in figures 1 and 2 . We consider the size and shape of the spermatheca (fig. 3) important for differentiating species and demonstrating relationships within species groups. Chant (1960a) argued against using that organ in taxonomy because its function was not known. However, since Dosse (1959) demonstrated that the coxal glands are, in fact, spermathecae, we consider their characteristics as useful for classification as those of the various plates and setae.
The terminology applied to the plates and setae is explained by figure 4 . The dorsal shield is described as though divided behind the third pair of dorsocentral setae into proscutum and postscutum. Such a division exists in Macroseius biscutatus Chant, Denmark, and Baker.

The setae on a specimen are numbered consecutively, counting from the anteriormost member of each series. This arbitrary scheme is a very workable way to designate the individual setae of a given specimen. However, it causes discrepancies that must be understood, because keys and diagnoses use the same numbers, I to VI, but sometimes with different meanings. In the keys, each seta is given the number of the homologous seta on a hypothetical ancestor, and missing setae are numbered as well as the remaining setae. In diagnoses, however, only the existing setae are numbered and, therefore, if any seta in a series is missing, serial numbering of posteriad setae of that series does not indicate homologies and does not correspond to the numbers used in the keys.

A properly prepared specimen examined with fine optical equipment reveals a wealth of characters. In the absence of breeding experiments or other biological information, it may be easier, at times, to distinguish individuals than to recognize differences between species. Therefore, it may eventually be found that some of the species considered in this paper consist of a species complex whereas others, which now seem remarkably distinct, may represent only infraspecific variants. The present confusion regarding the status of some species of phytoseiids will be resolved as specimens become available in greater numbers and from areas hitherto uncollected and as biological information supplements the present morphological basis for species recognition. Careful study of the variations in large populations is essential for adequate interpretations. 

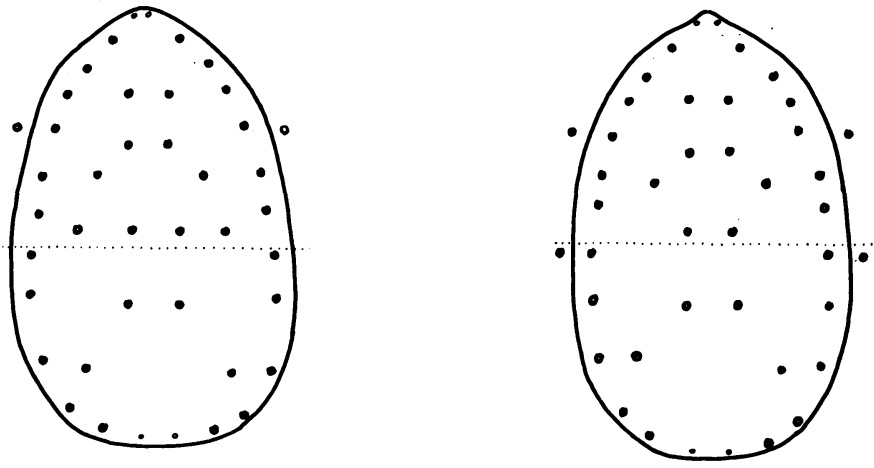

\section{Seiulus}

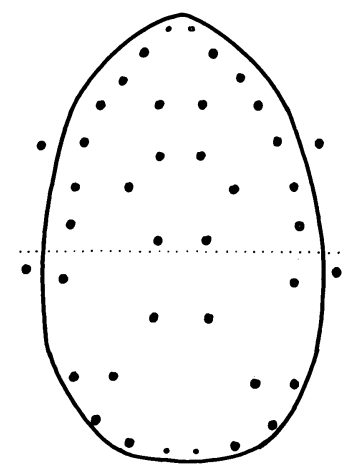

Neoseiulus

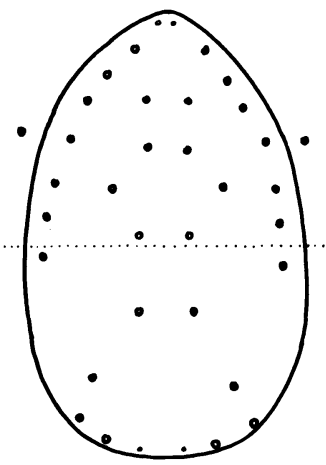

Metaseiulus

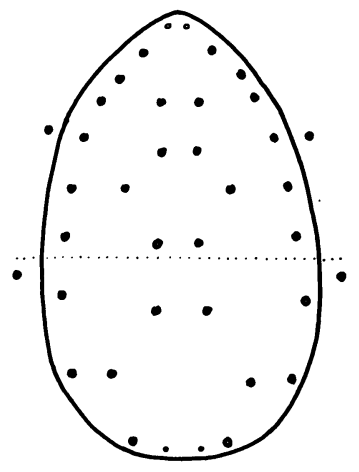

Typhlodromus

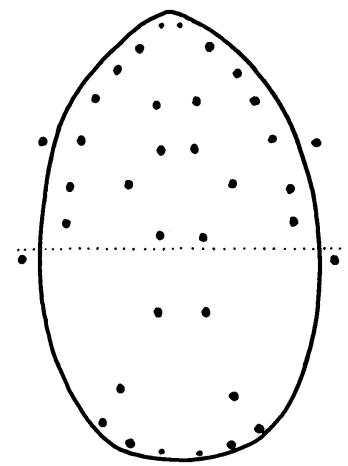

Typhloseiopsis

Fig. 1. Patterns of setal insertions for genera in the tribe Typhlodromini. 


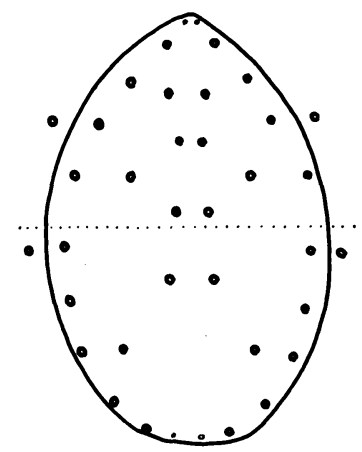

Amblyseius

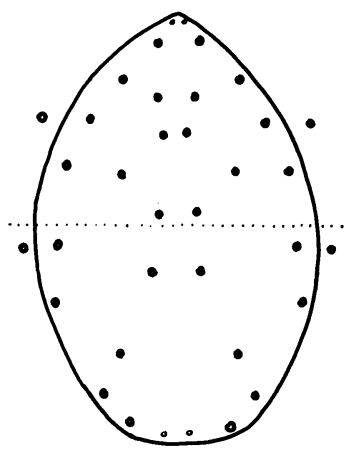

Kampimodromus

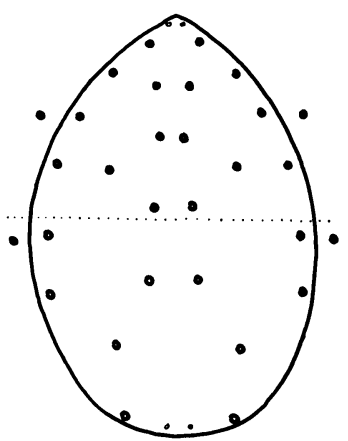

Asperoseius

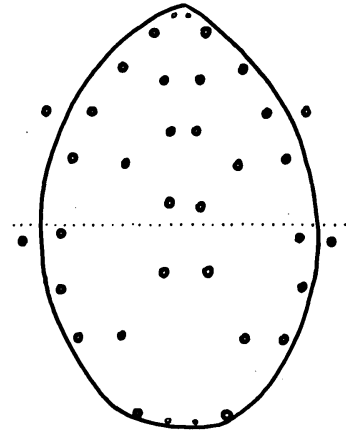

Amblyseiella

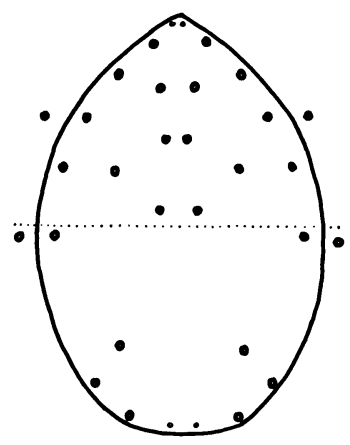

Phytoseiulus

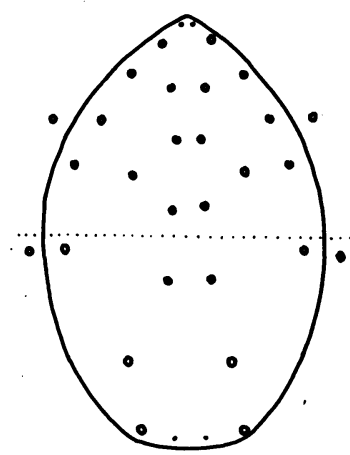

Ptenoseius

Fig. 2. Patterns of setal insertions for genera in the tribe Amblyseiini. 


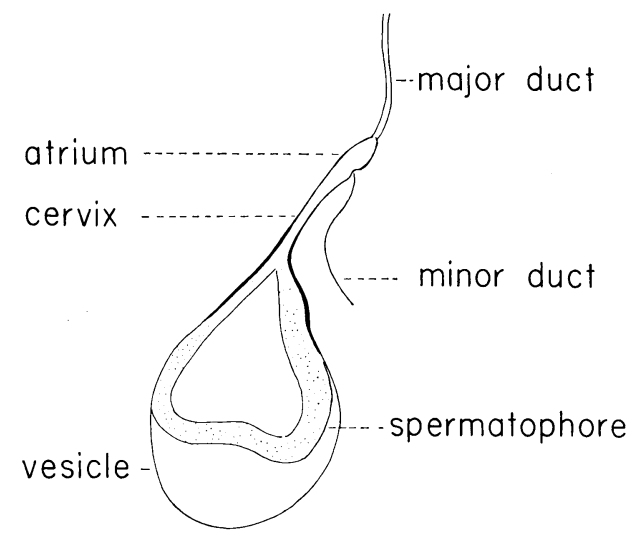

Fig. 3. Details of spermatheca of phytoseiid mite.

Certain characters that seem to be unstable in some species may, nevertheless, be of use in separating other species. These include: (1) the position or the absence of the fourth and fifth pairs of dorsocentral setae; (2) the number of pairs of preanal setae; (3) the extent of the anterolateral margins of the ventri-anal plate; (4) the position of the preanal pores; (5) the occurrence of the third pair of sternal setae on separate platelets, especially when their association with the sternal plate is normally tenuous; and (6) the occurrence of the second sublateral setae on the dorsal shield or on the lateral membrane. It would be unwise to propose names for specimens that vary from a described species in any of these characters unless there are other substantiating differences.

A particular seta may show differences in length on different specimens of a population. The variation is less noticeable in the shorter setae and becomes more noticeable as the setal length increases. An additional problem involving setal length arises when specimens are improperly mounted, because the same setae appear shorter when suberect than when appressed. Macrosetae on the dorsum are defined as those setae which are longer than the verticals.

Characteristics that are constant, or nearly so, among the species of phytoseiids are omitted from the diagnoses. The vertical and the clunal setae are always present. The para-anal, postanal, ventrocaudal, and genital setae are stable. The sternal plate normally bears three pairs of setae and the metasternal platelets one pair.

After the present manuscript was completed, Muma (1961) published a classification of the Phytoseiidae which departs from previous systems and from the system we are presenting here. As a result of Muma's paper, we made a few essential changes in our manuscript.

Two extremes of classification are now available in the literature: Chant adheres to an extremely conservative concept of genera and emphasizes similarity of taxa. He accurately defined Amblyseius (Chant, 1957b) as a group of species with only four pairs of prolateral setae and Typhlodromus as a group with six pairs. In spite of this degree of discontinuity, he classified the two groups as subgenera of Typhlodromus. Some other authors tend to be extremely liberal, and Muma emphasizes dissimilarity of taxa.

Wainstein (1962), apparently unaware of the papers by Muma (1961) and by Karg (1961), proposed a division of the phytoseiids somewhat more moderate than that suggested by Muma. 

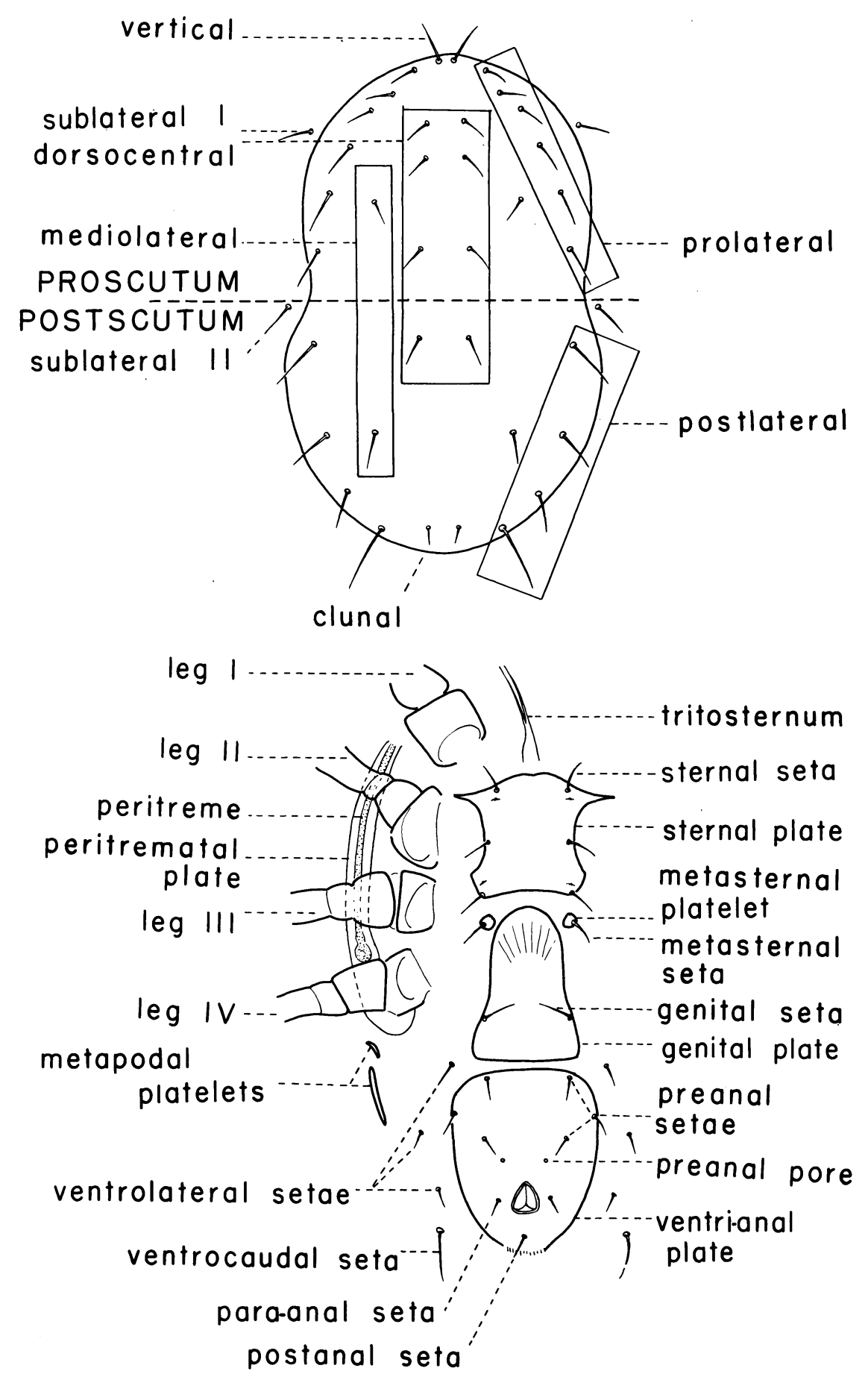

Fig. 4. Above, diagram showing locations of dorsal setae of phytoseiid mite; below, ventral aspect of phytoseiid mite, with terminology of plates and setae. 
Unfortunately, the majority of Wainstein's genera and subgenera had already been described, so the names proposed for them must become synonyms, as are the names for the three tribes that he proposed.

Although we feel that Muma's classification does not entirely reflect natural groupings within the phytoseiids, there is no need to propose changes in classi-

\section{Tribes and Genera Proposed or Rec- ognized in the Present Paper}

Tribe Typhlodromini

Seiulus Berlese

Neoseiulus Hughes

Typhloseiopsis De Leon

Typhlodromus Scheuten

Metaseiulus Muma

Tribe Amblyseiini

Amblyseius Berlese

Amblyseiella Muma

Kampimodromus Nesbitt

Proprioseius Chant

Phytoseiulus Evans

Asperoseius Chant

Ptenoseius Pritchard and Baker

Tribe Iphiseiini

Iphiseius Berlese

Tribe Chantiini

Chantia Pritchard and Baker fication beyond the scope of our paper, which deals with a relatively limited fauna. We are proposing two of Muma's genera-Galendromus and Metaseiulus - as synonyms, because California species are concerned. An informal comparison (see below) between our proposed division of the phytoseiids and Muma's published classification may be of interest.

\section{Genera Considered or Proposed by Muma (1961)}

Amblydromella, Australiseiulus, Neoseiulella, Seiulus, Typhloctonus

Anthoseius, ?Clavidromus, Neoseiulus, Paraseiulus, Typhlodromella

Amblydromus, Clavidromina, Galendromimus, Paraseiulella, Typhlodromina, Typhloseiopsis

Typhodromus

?Cydnodromella, Galendromus, Metaseiulus

Amblyseiulus, Amblyseius, Cydnodromus, Phyllodromus, Phytoscutella, Phytoseiulella, Typhloseius

Amblyseiella, Phytodromus, Typhloseiella

Paradromus

Phytoscutus, Proprioseiopsis, Proprioseius

Phytoseiulus

Amblyscutus, Amblyseiuella, Asperoseius 
Tribe Macroseiini

Macroseius Chant, Denmark, and Macroseius
Baker

Tribe Phytoseiini

Pennaseius Pritchard and Baker

Phytoseius Ribaga

Dubininellus, Phytoseius, Platyseiella

\section{FAMILY PHYTOSEIIDAE BERLESE}

Phytoseiini Berlese, 1916, p. 33.

Phytoseiinae Vitzthum, 1941, p. 767.

Phytoseiidae Baker and Wharton, 1952, p. 87.

\section{KEY TO TRIBES OF THE WORLD: FEMALES}

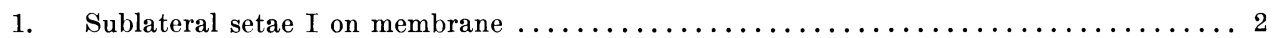

Sublateral setae $\mathrm{I}$ on a sclerotized plate $\ldots \ldots \ldots \ldots \ldots \ldots \ldots \ldots \ldots \ldots \ldots \ldots \ldots \ldots$

2(1). Proscutum with six pairs of prolateral setae, or else sublateral setae II absent

Typhlodromini (p. 199)

Proscutum with four pairs of prolateral setae............... Amblyseiini (p. 225)

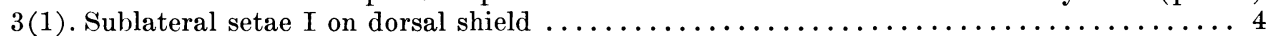

Sublateral setae I and II on sclerotized lateral area (tropics and semitropics)... Iphiseiini

4(3). Sublateral setae II on dorsal shield; dorsal shield with setae strongly spatulate and

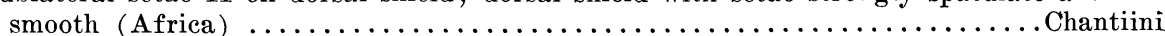

Sublateral setae II on lateral membrane, or absent; dorsal shield with setae serrate

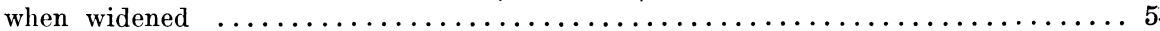

$5(4)$. Dorsal shield transversely divided (Florida) $\ldots \ldots \ldots \ldots \ldots \ldots \ldots \ldots \ldots \ldots \ldots \ldots \ldots \ldots \ldots \ldots$ Macrosini

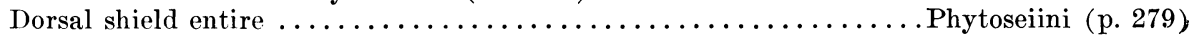

\section{TRIBE TYPHLODROMINI KARG}

Typhlodromidae Karg, 1961, p. 441.

Typhlodromini Wainstein, 1962, p. 26.

\section{KEY TO GENERA OF THE WORLD: FEMALES}

1. Postscutum with five pairs of postlateral setae (Old World; eastern United States) Seiulus

Postscutum with fewer than five pairs of postlateral setae $\ldots \ldots \ldots \ldots \ldots \ldots \ldots \ldots \ldots 2$

2(1). Postscutum with four pairs of postlateral setae (one pair of anterior postlateral setae

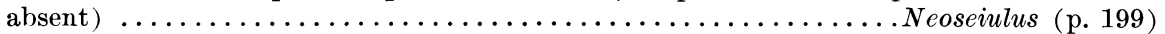

Postscutum with fewer than four pairs of postlateral setae $\ldots \ldots \ldots \ldots \ldots \ldots \ldots \ldots \ldots 3$

$3(2)$. Postscutum with three pairs of postlateral setae (only one pair of anterior postlateral

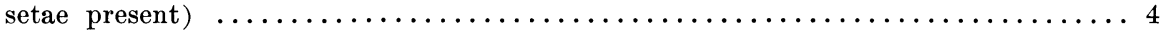

Postscutum with only the last two pairs of postlateral setae present. Typhloseiopsis (p. 205)

4(3). Postscutum with fourth pair of postlateral setae absent, the third postlateral setae located transversely to the postmediolateral setae............ Typhlodromus (p. 213)

Postscutum with fourth pair of postlateral setae present, the third pair absent Metaseiulus (p. 214)

\section{Genus Neoseiulus Hughes}

Neoseiulus Hughes, 1948, p. 141.

Typhlodromus (Neoseiulus) Nesbitt, 1951, p. 34.

\section{KEY TO CALIFORNIA SPECIES: FEMALES}

1. Dorsal shield with two pairs of mediolateral setae $\ldots \ldots \ldots \ldots \ldots \ldots \ldots \ldots \ldots \ldots \ldots \ldots$ Dorsal shield with three pairs of mediolateral setae ................ (1) soleiger

$2(1)$. Ventri-anal plate with four pairs of preanal setae $\ldots \ldots \ldots \ldots \ldots \ldots \ldots \ldots \ldots \ldots \ldots \ldots$ Ventri-anal plate with three pairs of preanal setae ................... s) singularis

$3(2)$. Sensory seta of basitarsus IV not appreciably longer than other tarsal setae (3) caudiglans Sensory seta of basitarsus IV much longer than other tarsal setae

(4) rhenanoides 

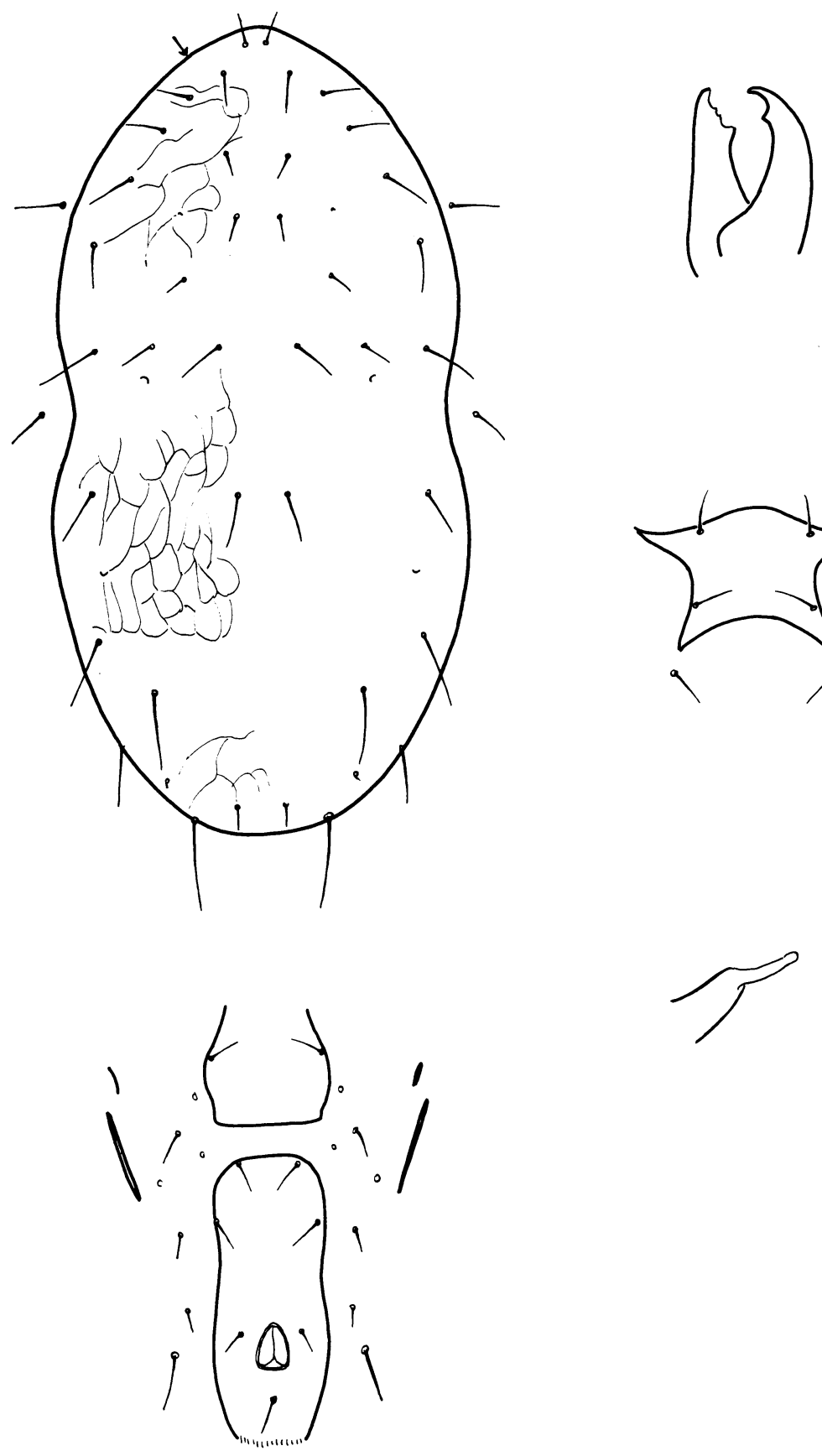

Fig. 5. Neoseiulus soleiger (Ribaga). 


\section{Neoseiulus soleiger (Ribaga), new combination}

(Fig. 5)

Seiulus soleiger Ribaga, 1902, p. 176.

Typhlodromus (Neoseiulus) soleiger (Ribaga). Nesbitt, 1951, p. 39.

Neoseiulus soleiger is distinctive among California phytoseiids in that it bears two pairs of mediolateral setae on the proscutum.

Female. Chelicera with two small subapical teeth on fixed digit, one large tooth on movable digit. Dorsal shield $390 \mu$ long, $220 \mu$ wide, reticulate except in area of dorsal rectangle and between postmediolateral setae. Vertical setae $17 \mu$; dorsocentrals I and II $23 \mu$, III $25 \mu$, IV $30 \mu$; clunals $13 \mu$; prolaterals I and II $25 \mu$, III $30 \mu$, IV and V $34 \mu$, VI $36 \mu$; postlaterals I-III $34 \mu$, IV $40 \mu$; promediolaterals I $23 \mu$, II $25 \mu$, postmediolaterals $30 \mu$; sublaterals I and II $30 \mu$; setae very fine, except postlaterals IV. Peritreme extending forward to base of prolateral I. Ventrianal plate $67 \mu$ wide, $125 \mu$ long, with two pairs of preanal setae. Primary metapodal platelets $65 \mu$ long, $4 \mu$ wide ; accessory platelets $17 \mu$ by $2 \mu$. Genital plate $65 \mu$ wide. Third pair of sternal setae on separate platelets. Cervix and atrium of spermatheca, combined lengths, about $17 \mu$. Longest seta of basitarsus of leg IV only $25 \mu$.

Male. Unknown.

\section{COLLECTION DATA}

Napa County: Napa, October 28 and November 11, 1958 (J. J. Skelsey). SAN JoAQUIN CoUnTy: Linden, January 22, 1954 (E. R. Oatman). (Known also from the eastern United States and from Europe.)

Found on Prunus domestica; also associated with tydeids under old frosted scale on walnut.

\section{Neoseiulus singularis (Chant) (Fig. 6)}

Typhlodromus singularis Chant, $1957 a$, p. 289. Neoseiulus singularis (Chant). Muma, 1961, p. 295.
The single specimen from California agrees with Chant's description of Typhlodromus singularis except that our specimen is larger and that the dorsal setae, particularly the sublaterals, are longer. The short, thick peritreme is a remarkable feature of the California specimen, but this structure was not described for $T$. singularis.

Female. Dorsal shield $380 \mu$ long, $195 \mu$ wide, reticulate. Vertical setae $25 \mu$; dorsocentrals I and II $21 \mu$, III and IV broken on specimen (estimated in illustration); clunals $12 \mu$; prolaterals I $27 \mu$, II $25 \mu$, III, and IV $30 \mu, \mathrm{V} 34 \mu$, VI $38 \mu$; postlaterals I $36 \mu$, II $38 \mu$, III $32 \mu$, IV $48 \mu$; promediolaterals $21 \mu$, postmediolaterals $32 \mu$; sublaterals I and II $34 \mu$; postlaterals IV minutely serrate. Peritreme short, thick, extending forward to about prolateral III. Ventrianal plate $80 \mu$ wide, $120 \mu$ long, with three pairs of preanal setae. Venter with three pairs of ventrolateral setae. Primary metapodal platelets $37 \mu$ long, $5 \mu$ wide; accessory platelets $12 \mu$ by $2 \mu$. Genital plate $70 \mu$ wide. Third pair of setae apparently separate from sternal plate. Metasternal platelets elongate. Spermatheca seemingly with the anterior half weakly sclerotized, collapsed in our specimen. Leg IV with sensory seta on basitarsus $34 \mu$.

Male. Unknown.

\section{COLLECTION DATA}

Lassen National Park, at 8,000 feet elevation, August 20, 1958 (C. D. Brickhill). (Recorded also from North Dakota and Oregon and from British Columbia.)

Found on a rosaceous plant.

\section{Neoseiulus caudiglans (Schuster), new combination}

(Fig. 7)

Typhlodromus caudiglans Schuster, 1959, p. 88.

This species is closely related to $\mathrm{Neo}$ seiulus vulgaris (Ehara). It differs in the relative lengths of postlateral setae II and III and of the postmediolaterals. The sensory setae of leg IV are longer 

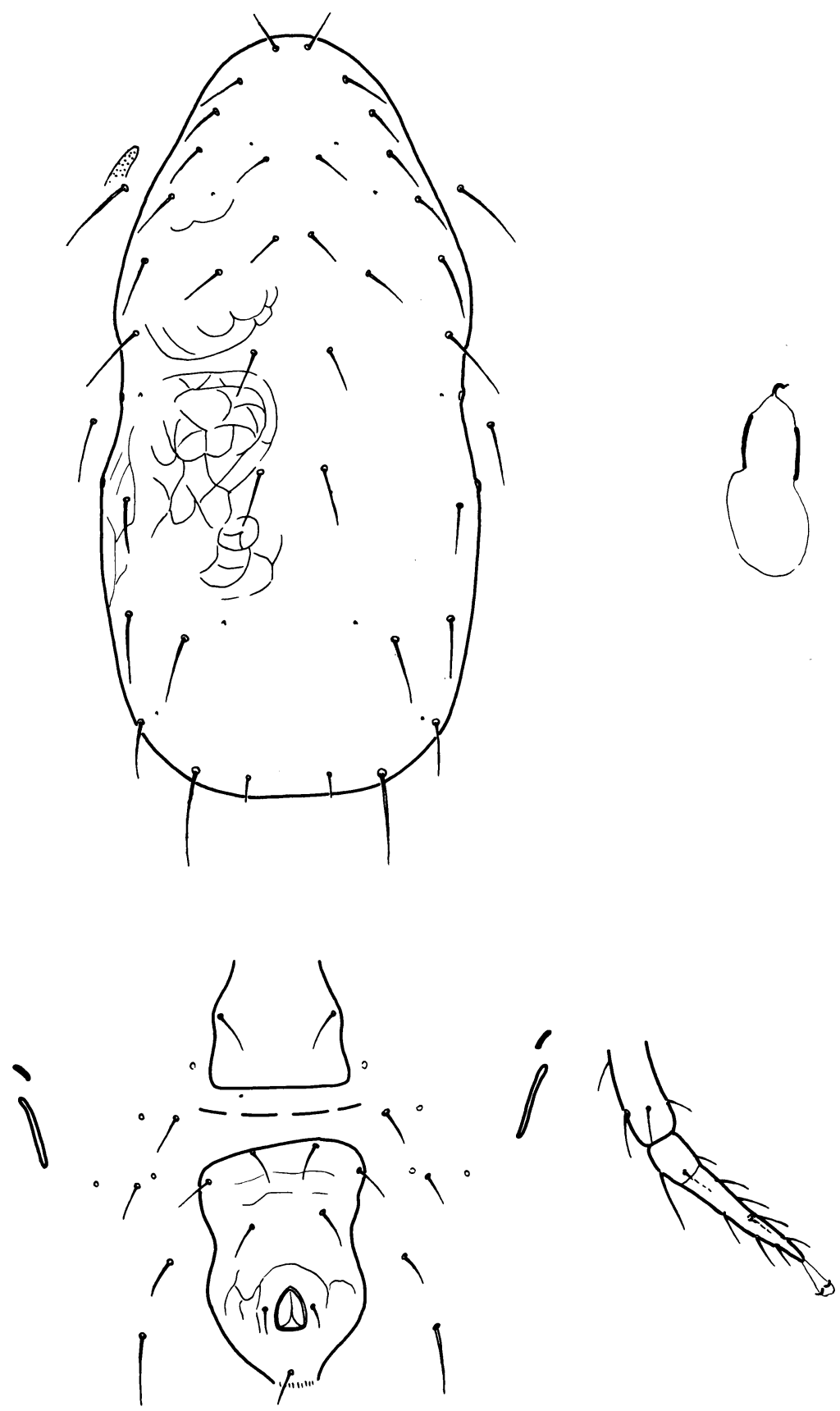

Fig. 6. Neoseiulus singularis (Chant). Tip of peritreme (stippled) is indicated at left of prolateral seta III. Posterior margin of genital plate is shown above the ventri-anal plate. 
than in $N$. vulgaris, and the ventri-anal plate is reticulate.

Female. Chelicera with three teeth on fixed digit, one on movable digit. Dorsal shield $355 \mu$ long, $300 \mu$ wide, generally reticulate. Vertical setae $22 \mu$; dorsocentrals I and II $14 \mu$, III and IV $17 \mu$; clunals $10 \mu$; prolaterals I $23 \mu$, II $17 \mu$, III $22 \mu$, IV and V $25 \mu$, VI $29 \mu$; postlaterals I and II $29 \mu$, III $25 \mu$, IV $55 \mu$; promediolaterals $17 \mu$, postmediolaterals
$25 \mu$; sublaterals $125 \mu$, II $23 \mu$; postmediolaterals and postlaterals IV serrate. Peritreme extending forward almost to base of vertical seta. Ventri-anal plate $85 \mu$ wide, $105 \mu$ long, reticulate, with four pairs of preanal setae and a pair of preanal pores. Three pairs of ventrolateral setae normally present. Primary metapodal platelets $22 \mu$ long, $6 \mu$ wide; accessory platelets $8 \mu$ by $2 \mu$. Genital plate $74 \mu$ wide. Spermatheca

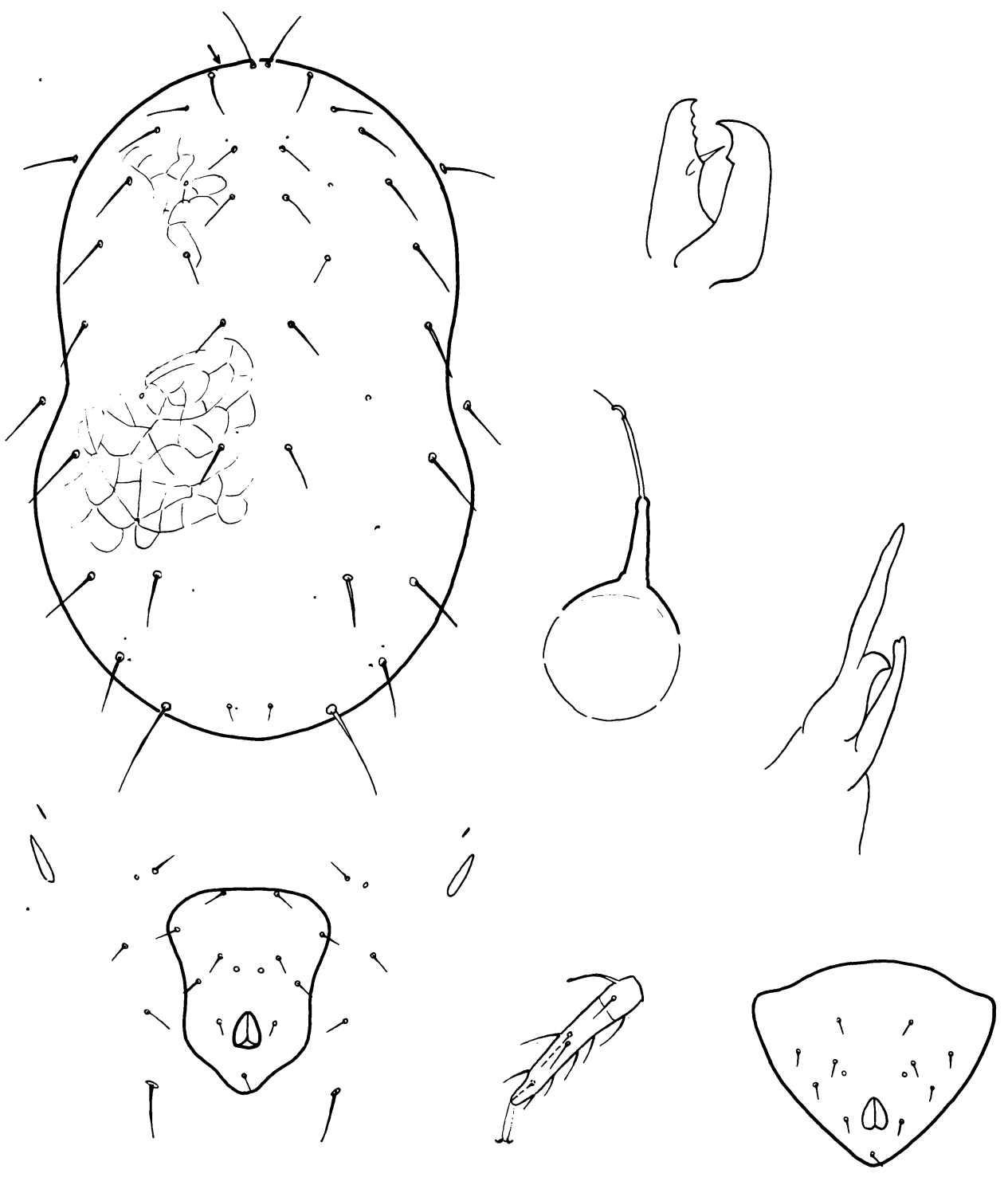

Fig. 7. Neoseiulus caudiglans (Schuster). 

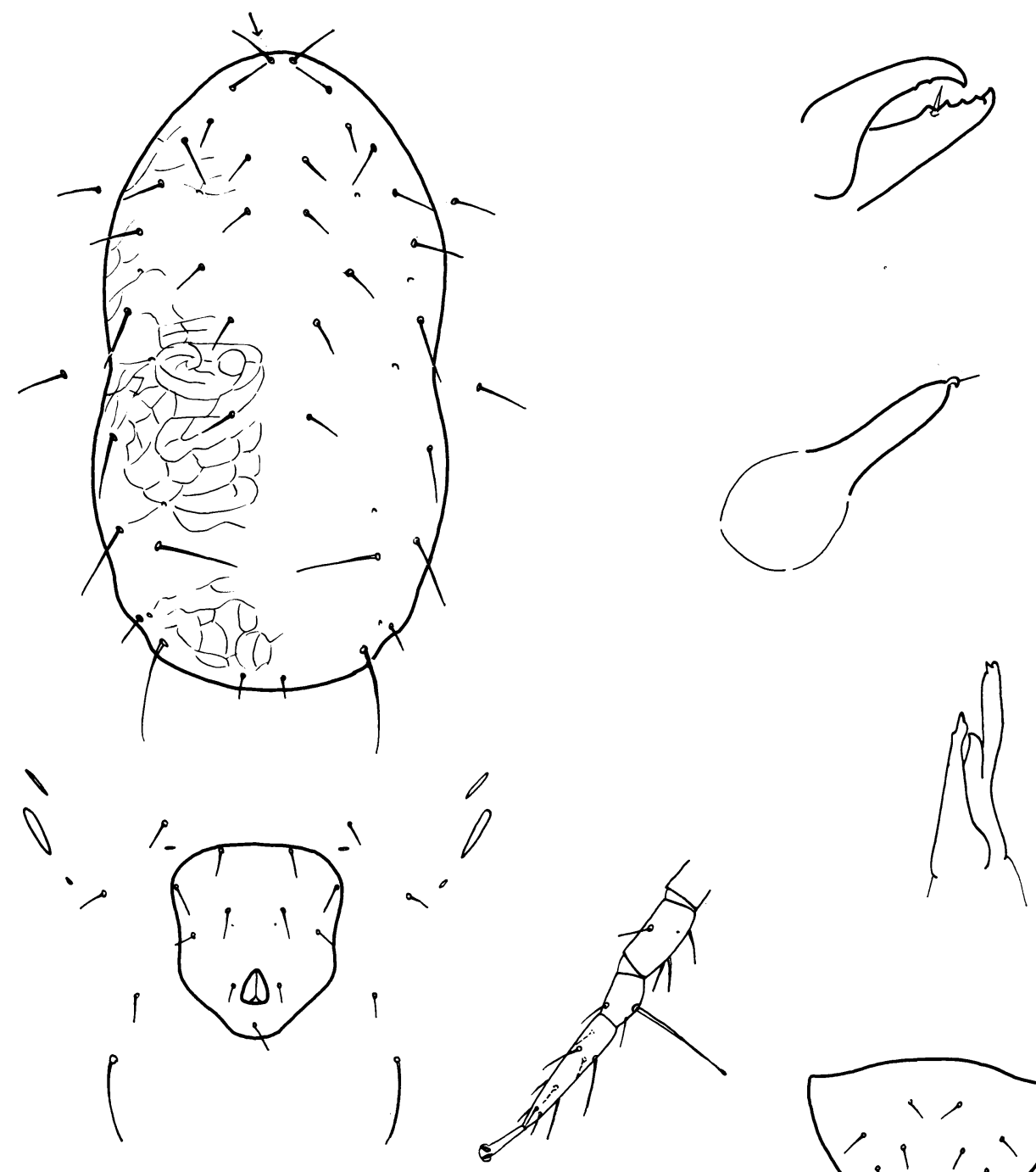

Fig. 8. Neoseiulus rhenanoides (Athias-Henriot).

with cervix and atrium, combined lengths, $19 \mu$. Leg IV with spatulate sensory seta on basitarsus $25 \mu$, on genu $14 \mu$; orientation of leg often makes the spatulate nature of these setae difficult to observe.

Male. Spermatodactyl usually appearing as a linear structure along the axis of the chelicera. Ventri-anal plate with four pairs of preanal setae and a pair of pores.
COLLECTION DATA

Contra Costa County: March 8, 1957 (R. Sanborn). NAPA County: Napa, September and October, 1958 (R. O. Schuster, J. J. Skelsey). Placer County: Foresthill, June 6, 1959 (F. C. Raney). SAN Joaquin County: Linden and Victor, November 25, 1957 (R. O. Schuster). Yolo County: Davis, June and August, 1957 (R. O. Schuster, L. M. Smith). 
Taken from grape, peach, plum, walnut, and mixed litter. Prey includes eriophyids on walnut and peach silver mite.

\section{Neoseiulus rbenanoides (Athias-Henriot), new combination} (Fig. 8)

Typhlodromus rhenanoides Athias-Henriot, 1962 , p. 85.

California populations of this species differ from Neoseiulus rhenanus (Oudemans) in the length of some of the dorsal setae and in the clavate rather than aciculate form of the macroseta of basitarsus IV.

Female. Chelicera with three teeth between apex and pilus dentilis, two teeth on movable digit. Dorsal shield $335 \mu$ long, $190 \mu$ wide, reticulate, but less so in area of dorsal rectangle and between the postmediolateral setae. Vertical setae $29 \mu$; dorsocentrals I and II $18 \mu$, III $22 \mu$, IV $25 \mu$; clunals $10 \mu$; prolaterals I $30 \mu$, II $17 \mu$, III $25 \mu$, IV $27 \mu, \mathrm{V} 31 \mu$, VI $34 \mu$; postlaterals I $37 \mu$, II $34 \mu$, III $17 \mu$, IV $63 \mu$; promediolaterals $21 \mu$, postmediolaterals $49 \mu$; sublaterals I and II $27 \mu$; postlaterals IV and postmediolaterals serrate. Peritreme extending forward nearly to base of vertical seta. Ventri-anal plate $95 \mu$ wide, $110 \mu$ long, with four pairs of preanal setae and a pair of very faint pores. Three pairs of ventrolateral setae present, and a few small platelets surrounding the ventri-anal plate. Primary metapodal platelets $27 \mu$ long, $5 \mu$ wide; accessory platelets $11 \mu$ by $3 \mu$. Genital plate $75 \mu$ wide. Third pair of sternal setae separate from plate; metasternals on small platelets. Cervix and atrium of spermatheca, combined lengths, about $25 \mu$. Leg IV with macroseta on basitarsus $57 \mu$; macrosetae of tibia and genu only $25 \mu$, slightly thicker than other setae.

Male. Spermatodactyl normally extending along axis of chelicera. Ventrianal plate with four pairs of preanal setae.

\section{COLLECTION DATA}

Alameda County: Berkeley, June 15, 1958, June 30 and August 17, 1959 (B. E. Pullen). Marin County: Muir Woods, August 1, 1959 (B. E. Pullen). San Mateo County: Redwood City, September 2, 1957 (R. O. Schuster).

Taken on Ligustrum, Magnolia, Oxalis oregana, Peumus boldus, Prunus domestica, and Quercus. This mite has been found preying on tetranychids.

\section{Genus Typhloseiopsis De Leon}

Typhloseiopsis De Leon, $1959 a$, p. 150.

\section{KEY TO CALIFORNIA SPECIES: FEMALES}

1. Ventri-anal plate with four pairs of preanal setae $\ldots \ldots \ldots \ldots \ldots \ldots \ldots \ldots \ldots \ldots \ldots$

Ventri-anal plate with two pairs of preanal setae .................. (1) smithi

2(1). Prolateral setae V of length sufficient to reach bases of VI ............ (2) conspicuus

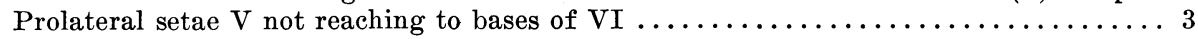

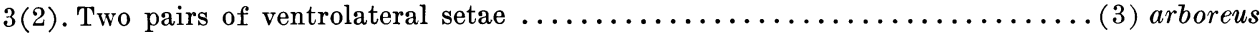

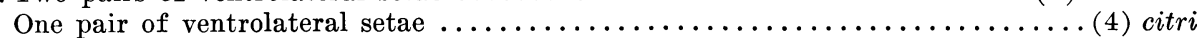

\section{Typhloseiopsis smitbi (Schuster), new combination}

(Fig. 9)

Typhlodromus smithi Schuster, 1957, p. 203.

The short peritreme, extending only to sublateral seta I, and the presence of only two pairs of preanal setae in the female distinguish this species.
Female. Chelicera with two subapical teeth on fixed digit, one on movable digit. Dorsal shield $390 \mu$ long, $230 \mu$ wide, reticulate. Vertical setae $32 \mu$; dorsocentrals I $23 \mu$, II $25 \mu$, III $34 \mu$, IV $44 \mu$; clunals $13 \mu$; prolaterals I $38 \mu$, II $32 \mu$, III $37 \mu$, IV $40 \mu$, V $46 \mu$, VI $51 \mu$; postlaterals I $26 \mu$, II $65 \mu$; promediolaterals $23 \mu$, postmediolaterals $64 \mu$; sub- 

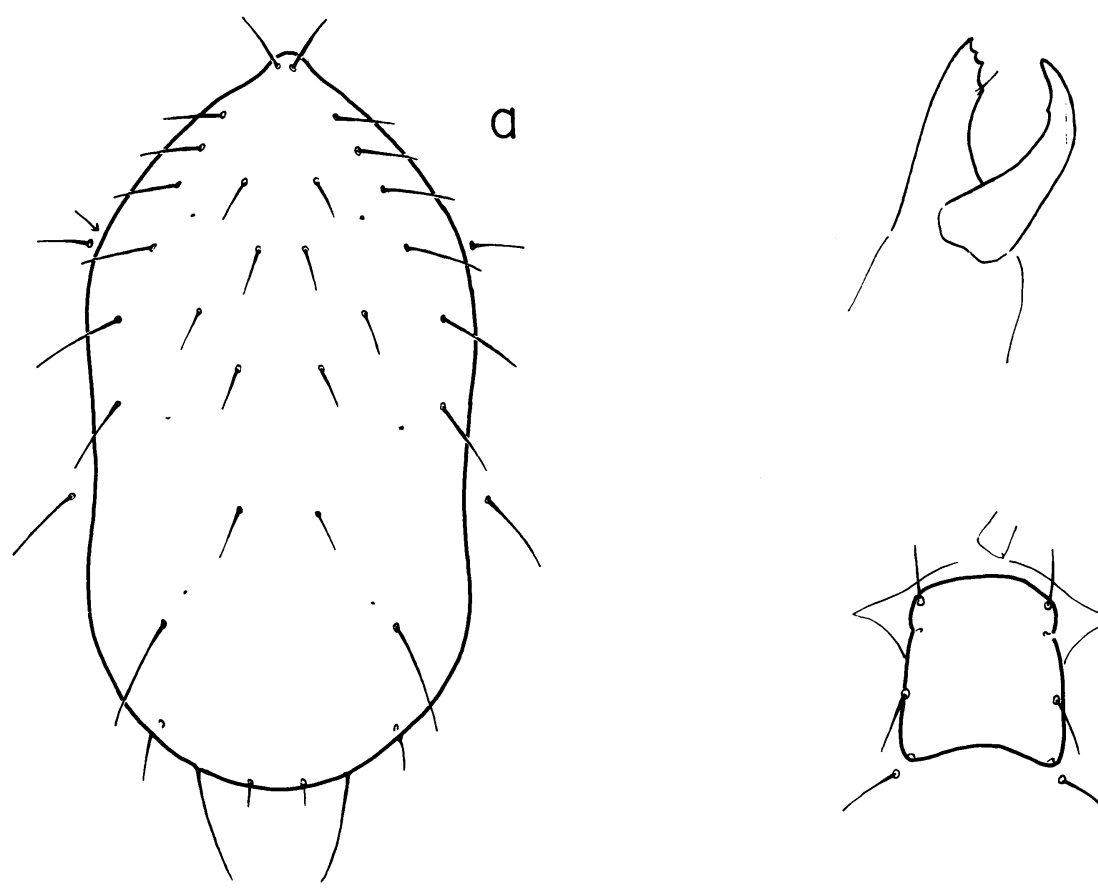

C

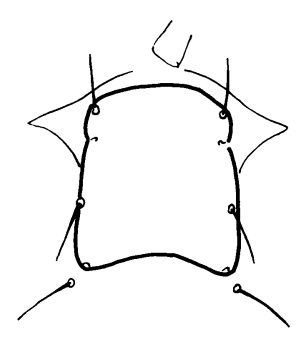

d
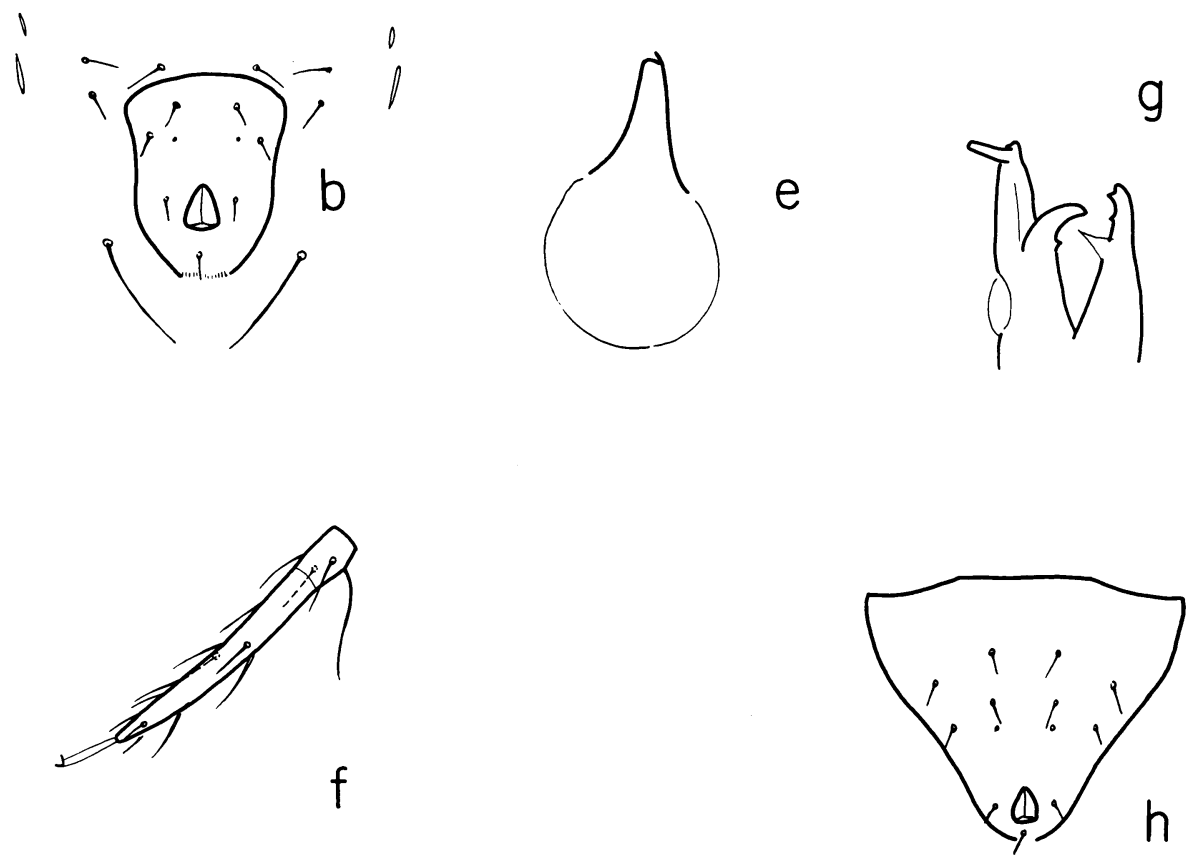

Fig. 9. Typhloseiopsis smithi (Schuster). Female: a, dorsal shield, extent of peritreme indieated by arrow; $b$, ventri-anal plate, ventrolateral and ventrocaudal setae, and metapodal platelets; $c$, chelicera; $d$, sternal plate; $e$, spermatheca; $f$, leg IV, tarsus and basitarsus. Male: $g$, spermatodactyl; $h$, ventri-anal plate. Most of the above structures are shown also in figures 5 through 54. 
laterals I $33 \mu$, II $50 \mu$; postmediolaterals and postlaterals II serrate. Peritreme extending forward to about prolateral seta IV. Ventri-anal plate $85 \mu$ wide, $125 \mu$ long, with two pairs of preanal setae and a pair of pores. Primary metapodal platelets $36 \mu$ long, $5 \mu$ wide; accessory platelets $17 \mu$ by $3 \mu$. Genital plate $95 \mu$ wide. Sternal plate weakly sclerotized, the third pair of setae and the metasternal setae apparently unassociated with platelets. Cervix and atrium of spermatheca, combined lengths, about $17 \mu$. Leg IV with macroseta on basitarsus $65 \mu$.

Male. Spermatodactyl with distal portion of shaft short, thin, nearly perpendicular to the proximal part. Ventrianal plate with four pairs of preanal setae and a pair of pores.

\section{COLLECTION DATA}

Placer County: 4 miles west of Newcastle, January 3, 1959 (F. C. Raney, R. O. Schuster). SAN Diego County: State Highway 78 between Julian and Ramona, December 26, 1958 (L. M. Smith). San Joaquin County: Acampo, Lodi, and Victor, various dates, 1956 and 1957 (R. O. Schuster, L. M. Smith).

Taken from Vitis vinifera and mixed litter of Bromus, Ceanothus, and Quercus. This mite has been reared on Eriophyes vitis.

\section{Typbloseiopsis conspicuus (Garman), new combination}

(Fig. 10)

Iphidulus conspicuus Garman, 1948, p. 14.

Typhlodromus conspicuus (Garman). Nesbitt, 1951, p. 22.

We have not seen the type specimens of either Typhloseiopsis conspicuus or Typhlodromus tropicus (Chant), a species very closely related to conspicuus. The California population more closely resembles conspicuus in general appearance, although it has the dorsal setae serrate as in tropicus. It has the same numbers of dorsal setae as have Typhloseiopsis citri, T. smithi, and $T$. theodoliticus (De Leon), but the shape of the spermatheca of the female and the reduced ventri-anal plate of the male show little relation to those species.

Female. Chelicera with two subapical teeth on fixed digit, one on movable digit. Dorsal shield $400 \mu$ long, $270 \mu$ wide, faintly but uniformly reticulate. Vertical setae $34 \mu$; dorsocentrals I $31 \mu$, II $40 \mu$, III $51 \mu$, IV $65 \mu$; clunals $17 \mu$; prolaterals I $46 \mu$, II $40 \mu$, III $46 \mu$, IV and V $54 \mu$, VI $76 \mu$; postlaterals I $70 \mu$, II $65 \mu$; promediolaterals $42 \mu$, postmediolaterals $76 \mu$; sublaterals I and II $34 \mu$; all setae minutely serrate except postlaterals I. Peritreme extending forward to about prolateral seta II. Ventrianal plate $100 \mu$ wide, $145 \mu$ long, with four pairs of preanal setae and a pair of pores. Venter with two pairs of ventrolateral setae. Primary metapodal platelets $28 \mu$ long, $6 \mu$ wide ; accessory platelets $12 \mu$ by $3 \mu$. Genital plate $92 \mu$ wide. Sternal plate with two pairs of setae, third pair normally on large, discontinuous or narrowly attached platelets. Metasternal platelets small. Cervix of spermatheca $21 \mu$ long, bluntly rounded; atrium distinct but no wider than major duct. Leg IV with inconspicuous macroseta on basitarsus $60 \mu$.

Male. Spermatodactyl with distal part arising below apex of proximal part, protruding at right angles to it, and extended terminally. Ventri-anal plate reduced, with a large remnant at each anterolateral margin; with four, five, or six pairs of preanal setae and a pair of pores.

\section{COLLECTION DATA}

Humboldt County: Eureka, October 3, 1958 (E. Eberweine, W. Appel). Marin County: Black Point, March 24, near Bolinas, April 7, and 6 miles east of Point Reyes Station, March 24, 1960 (R. O. Schuster). Napa County: Napa, various dates 1958 and 1959 (R. O. Schuster, J. J. Skelsey). SAN JoAQUIN County: Linden, November 25, 1957 (R. O. Schuster). San Mateo County: 


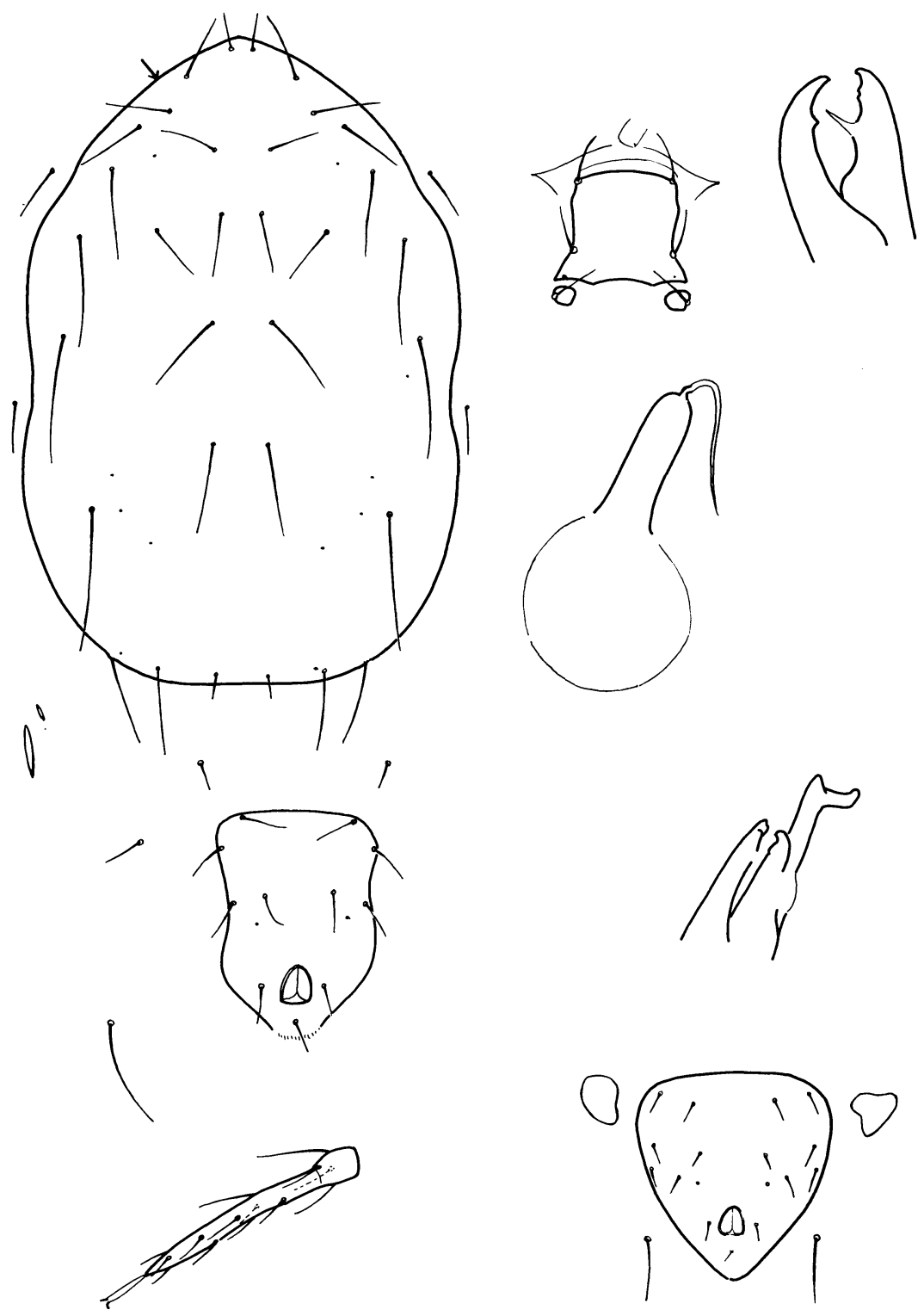

Fig. 10. Typhloseiopsis conspicuus (Garman).

4 miles south of Half Moon Bay, July 24, 1960 (R. O. Schuster). Sonoma County: 1 mile south of Trenton, August 7 and September 3, 1957 (R. O. Schuster, L. M. Smith).

Found on Juglans, Prunus domestica, Quercus, Vitis, and Weigelia. This mite has been reared on Tetranychus telarius.

\section{Typbloseiopsis arboreus (Chant),} new combination

$$
\text { (Fig. 11) }
$$

(Typhlodromus) arboreus

Typhlodromus (Typ
Chant, $1957 a$, p. 292.

Typhlodromus anchialus Kennett, 1958, p. 473. New synonomy.

The holotype of Typhloseiopsis anchialus has two pairs of ventrolateral setae and therefore resembles $T$. arbo- 
reus. However, the paratypic series of T. anchialus is a mixture of specimens with either one or two pairs of ventrolateral setae. In specimens of the form with two pairs, there is a continuous variation in the length of the second postlateral setae, from $51 \mu$ to $67 \mu$. On the paratype specimen of $T$. arboreus that we measured, the second postlaterals were $56 \mu$ long; on the holotype of
T. anchialus, they measured $59 \mu$. In both forms, the postmediolateral setae vary from $34 \mu$ to $44 \mu$; they measured $42 \mu$ on the specimen of $T$. arboreus and $40 \mu$ on the holotype of T. anchialus. Because both of these specimens are very poor mounts, the following diagnosis is based on a specimen from the Olympic Peninsula, Washington. Incidentally, the paratype specimen of $T$. arboreus
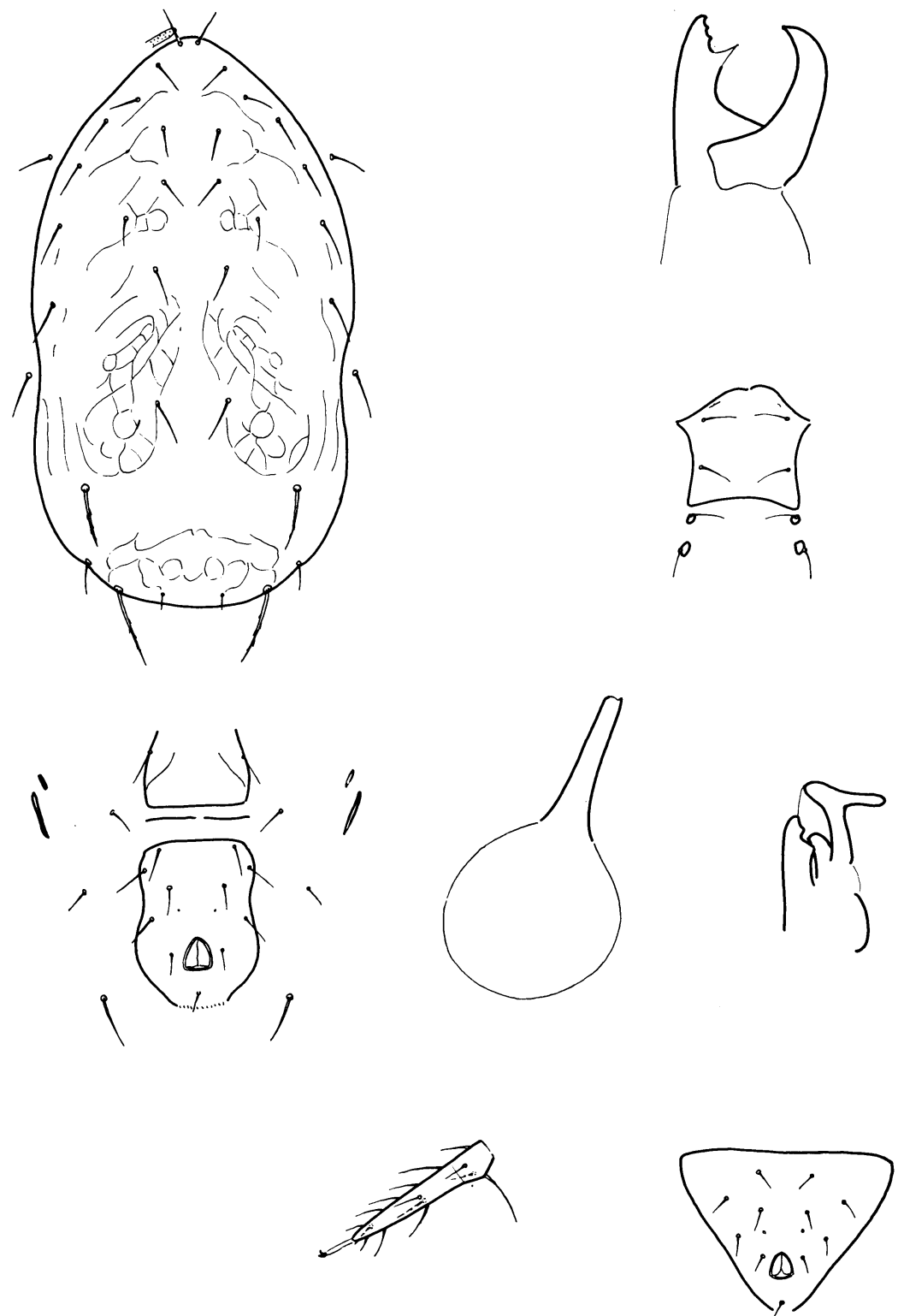

Fig. 11. Typhloseiopsis arboreus (Chant). 
that we studied has the postmediolateral setae and postlateral setae II distinctly serrate; thus it keys in Chant's monograph (1960a) to Typhlodromus perplexus (Chant).

Female. Chelicera with two subapical teeth on fixed digit, probably one on movable digit. Dorsal shield $350 \mu$ long, $210 \mu$ wide, reticulate, but weakly so between mediolateral setae II. Vertical setae $25 \mu$; dorsocentrals I and II $22 \mu$, III $27 \mu$, IV $30 \mu$; clunals $15 \mu$; prolaterals I $30 \mu$, II $24 \mu$, III-V $34 \mu$, VI $39 \mu$; postlaterals I $24 \mu$, II $56 \mu$; promediolaterals $22 \mu$, postmediolaterals $42 \mu$; sublaterals I $34 \mu$, II $38 \mu$; postmediolaterals and postlaterals II faintly serrate. Peritreme extending forward to base of vertical seta. Ventri-anal plate $80 \mu$ wide, $110 \mu$ long, with four pairs of preanal setae and a pair of small pores. Venter with two pairs of ventrolateral setae. Primary metapodal platelets $27 \mu$ long, accessory platelets $8 \mu$ long. Genital plate $70 \mu$ wide. Third pair of sternal setae usually on separate platelets; metasternal platelets small but distinct. Cervix and atrium of spermatheca tubular, their combined lengths about $20 \mu$. Leg IV with macroseta on basitarsus $34 \mu$.

Male. Ventri-anal plate with four pairs of preanal setae.

\section{COLLECTION DATA}

Alameda County: Oakland, September 8, 1957 (R. O. Schuster); December 26, 1959 (J. F. Laurence). MARIN County: Black Point and Bolinas, March 24, 1960 (R. O. Schuster); Inverness, July 14, 1960 (S. F. Bailey, L. Stange); McClure Beach, October 2, 1960 (J. S. Buckett). Mendocino County: Talmage, July 29, 1959 (R. O. Schuster, L. M. Smith). NAPA County: Mount Eden Vineyards, June 23, 1958 (R. O. Schuster); Mount St. Helena, February 3, 1959 (S. F. Bailey); Napa, June 3, 1958 (J. J. Skelsey); Rutherford, December 11, 1957 (S. F. Bailey); 3 miles northeast of Saint Helena, December 15, 1958 (F.
C. Raney). Riverside County: Riverside, December 27, 1958 (F. C. Raney). San Benito County: Cienega Valley, southwest of Hollister, April, 1959 (Roy McCallum). SAN JOAQUIN County: Linden, November 25, 1957 (R. O. Schuster). San Mateo County: Half Moon Bay, June 3, 1958 (F. E. Strong); 4 miles south of Half Moon Bay, July 24 and September 25, 1960 (R. O. Schuster). Santa Clara County: Morgan Hill, January 29, 1958 (S. F. Bailey); San Jose, June 9, 1953 (W. W. Allen). Santa CRUz County: Santa Cruz, July 23, and Soquel, July 17, 1952 (W. W. Allen); Watsonville, October 13, 1953 (C. E. Kennett). Sonoma County: Agua Caliente, June 5, and near Maacama Creek, February 3, 1959 (R. O. Schuster) ; 10 miles south of Santa Rosa, March 27, 1957 (R. O. Schuster, L. M. Smith); 1 mile south of Trenton, August 7, 1957 (R. O. Schuster). Yolo County: Davis, June 28, 1957 (R. O. Schuster). (We have seen specimens from Oregon and Washington and from British Columbia.)

Found on Alnus catkins; Arbutus, Cynara scolymus, Juglans, Lupinus, Magnolia, Polyporus versicolor, Prunus domestica, Quercus, Rubus spectabilis, Salix, Tamarix, Umbellularia, and Vitis. Prey, when established, was Eriophyes vitis and other eriophyids, Steneotarsonemus pallidus, and Tetranychus telarius.

\section{Typhloseiopsis citri (Garman and McGregor), new combination} (Fig. 12)

Typhlodromus citri Garman and McGregor, 1956, p. 8.

Typhlodromus pacificus McGregor, 1956, p. 8.

Typhlodromus pacificus McGregor. Chant, $1960 a$, p. 53.

Typhlodromus (Typhlodromus) pini Chant. Chant, $1960 a$, p. 53.

In the type specimens of both Typhloseiopsis citri and T. pacificus, there is only one pair of ventrolateral setae. If the presence or absence of a second pair is a specific character, then $T$. citri 
is not, as proposed by Chant (1960a), mediolateral setae, from $23 \mu$ to $42 \mu$, and a synonym of Typhlodromus pini in the length of postlateral setae II, Chant, which has two pairs. Specimens from $45 \mu$ to $60 \mu$. Thus, specimens with of Typhloseiopsis citri show a continu- the longer postmediolaterals approach ous variation in the length of the post- Typhlodromus (Typhlodromus) colum-
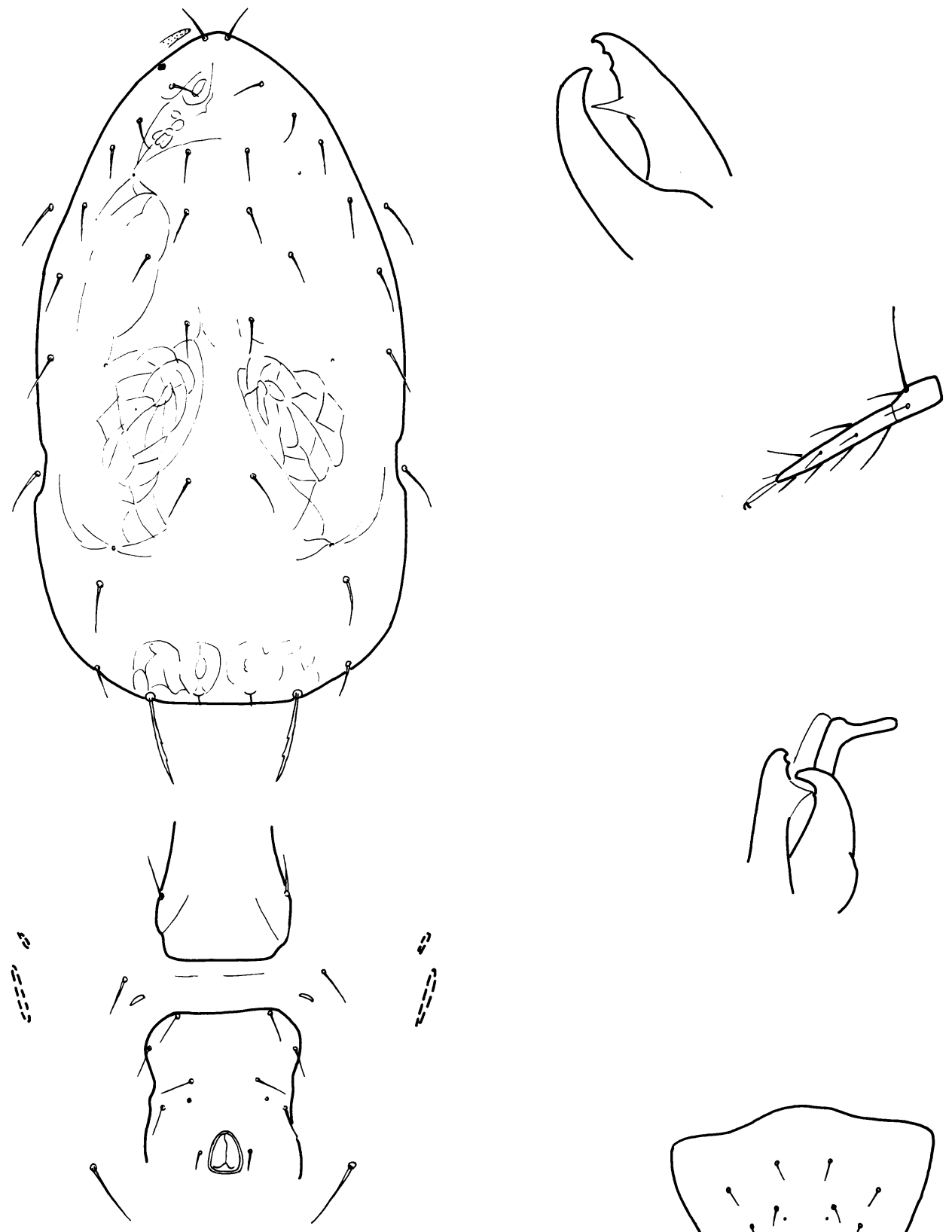

Fig. 12. Typhloseiopsis citri (Garman and McGregor). 


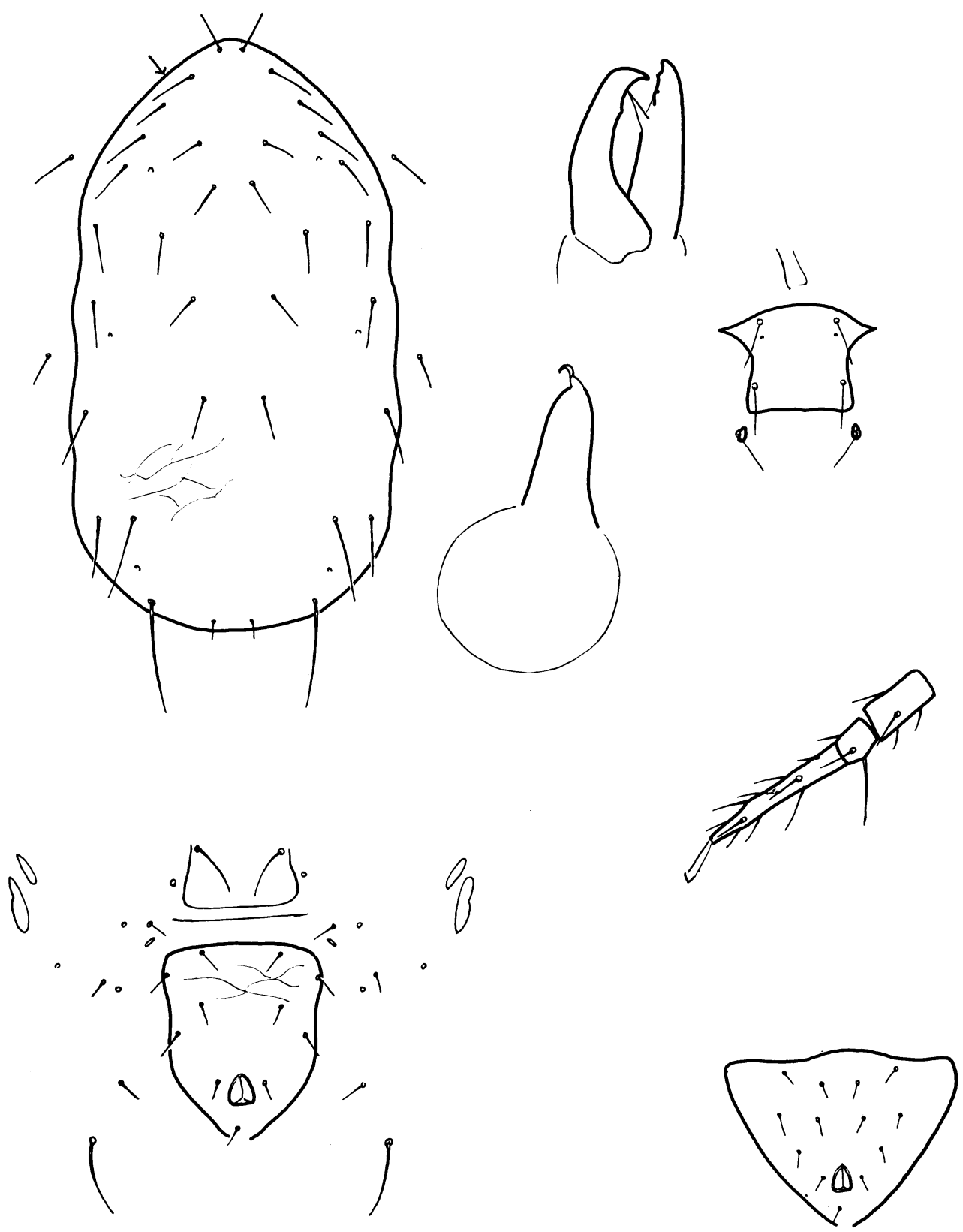

Fig. 13. Typhlodromus pyri Scheuten.

biensis Chant, and some California specimens have been determined by Chant (in correspondence) as T. columbiensis.

Typhloseiopsis citri closely resembles $T$. arboreus. In fact, the type specimen of $T$. citri keys out, in Chant's (1960a) monograph, to "Typhlodromus anchialus Kennett," which we consider a synonym of Typhloseiopsis arboreus. However, two species may exist in California. In T. arboreus, there are two pairs of ventrolateral setae and the basitarsal macroseta on leg IV is usually short, 
about $35 \mu$. In $T$. citri, there is one pair of ventrolateral setae, and the macroseta of basitarsus IV is about $50 \mu$. There are intergrades between these forms, especially in specimens from Marin County, where the venter frequently has two ventrolateral setae on the left side and one on the right. At present, it is not possible to analyze these populations or to perform the breeding experiments needed for determining their status. The spermathecae of the two forms seem to be alike.

Female. Chelicera with two subapical teeth on fixed digit, movable digit apparently smooth. Dorsal shield $385 \mu$ long, $220 \mu$ wide, reticulate, except in an area between the postmediolateral setae. Vertical setae $25 \mu$; dorsocentrals I and II $17 \mu$, III $19 \mu$, IV $21 \mu$; clunals $8 \mu$; prolaterals I $24 \mu$, II $19 \mu$, III $21 \mu$, IV-VI $22 \mu$; postlaterals I $19 \mu$, II $41 \mu$; promediolaterals $17 \mu$, postmediolaterals $29 \mu$; sublaterals I and II $25 \mu$; postlaterals II usually serrate. Peritreme extending forward to base of vertical seta. Ventri-anal plate $85 \mu$ wide, $120 \mu$ long, with four pairs of preanal setae and a pair of pores. One pair of ventrolateral setae. Primary metapodal platelets $30 \mu$ long, $5 \mu$ wide; accessory platelets $12 \mu$ by $3 \mu$. (On the holotype these platelets were obscured, so they are shown dotted in the illustration.) Genital plate $75 \mu$ wide. Sternal plate with two pairs of setae, the third pair usually on small, separate platelets; metasternal platelets small. Sperma- theca as in T. arboreus. Leg IV with macroseta on basitarsus $50 \mu$.

Male. Ventri-anal plate with four pairs of preanal setae and a pair of pores.

\section{COLLECTION DATA}

Butte County: Gridley, August 25, 1958 (J. J. Skelsey). Los Angeles County: Whittier Heights, April 18, 1952 (F. Munger). Mendocino County: Redwood Valley, July 28, 1959 (R. O. Schuster, L. M. Smith). NaPA County: Mount St. Helena, February 3, 1959 (S. F. Bailey); Napa, various dates, 1958 (R. O. Schuster, J. J. Skelsey); Rutherford, December 11, 1957 (S. F. Bailey). SAN JoAqUIN County: Linden, November 15 and 25, 1957 and Lodi, January 29, 1957 (R. O. Schuster, L. M. Smith). Solano County: junction of Highways 40 and 12, June 21, 1958 (J. J. Skelsey). SoNoma County: near Maacama Creek, December 20, 1958 and 10 miles south of Santa Rosa, April 18, 1957 (R. O. Schuster, L. M. Smith). Stanislaus County: Modesto, March 27, 1949. Riverside County: Corona, June 16, 1935 (H. Yust). Yolo County: Davis, various dates, 1957 and 1958 (R. O. Schuster). (The type specimens came from Whittier and Corona.)

Found on Citrus, Juglans, Magnolia, Prunus amygdalus, P. domestica, Quercus lobata, Sequoia, and Vitis, and the lichen Ramalina reticulata. This mite has been found feeding on Eriophyes vitis and other eriophyids.

\section{Genus Typhlodromus Scheuten}

Typhlodromus Scheuten, 1857, p. 111.

Typhlodromus (Typhlodromus), Chant, $1957 b$, p. 530 .

\section{Typhlodromus pyri Scheuten \\ (Fig. 13)}

Typhlodromus pyri Scheuten, 1857, p. 104.

Typhlodromus tiliae Oudemans, 1929, p. 14.

Typhlodromus tiliae Oudemans. Chant, 1960a, p. 64.

Specimens of Typhlodromus pyri from California agree, in general, with those from the eastern United States and from Europe. In the California population, the pair of large pores anterior to the postmediolateral setae is lacking, and the macroseta of the basitarsus is shorter than in the eastern population.

Female. Chelicera with two subapical teeth on fixed digit, one on movable digit. Dorsal shield $325 \mu$ long, $180 \mu$ wide, most strongly reticulate in an area bordered by dorsocentral setae IV, 
postmediolaterals, and postlaterals I. Vertical setae $23 \mu$; dorsocentrals I-III $18 \mu$, IV $25 \mu$; prolaterals I $30 \mu$, II $21 \mu$, III and IV $28 \mu$, V $30 \mu$, VI $40 \mu$; postlaterals I and II $40 \mu$, III $65 \mu$; promediolaterals $18 \mu$, postmediolaterals $47 \mu$; sublaterals I $30 \mu$, II $25 \mu$; postmediolaterals and postlaterals III serrate. Peritreme extending forward to base of prolateral II. Ventri-anal plate $87 \mu$ wide, $100 \mu$ long, with four pairs of preanal setae. Three pairs of ventrolateral setae normally surrounding the ventri-anal plate, but one seta of the center pair often lacking. Primary metapodal platelets $25 \mu$ long,
$4 \mu$ wide; accessory platelets $10 \mu$ by $2 \mu$. Genital plate $85 \mu$ wide. Cervix and atrium of spermatheca, combined lengths, about $21 \mu$. Leg IV with macroseta on basitarsus $34 \mu$.

Male. Ventri-anal plate with five pairs of preanal setae, or fewer.

\section{COLLECTION DATA}

Sonoma County: 1 mile south of Trenton, August and September, 1957 (R. O. Schuster, L. M. Smith). (Known also from the eastern United States and from Europe.)

Taken from grape, feeding on the erinose strain of Eriophyes vitis.

\section{Genus Metaseiulus Muma}

Metaseiulus Muma, 1961, p. 295.

Galendromus Muma, 1961, p. 298. New synonymy.

Muma proposed the genus Galendromus, separate from Metaseiulus, on the basis of two, not three, pairs of setae on the sternal plate and four, not three, pairs of preanal setae. However, in all of the specimens of Metaseiulus validus that we have seen, the sternal plate ends with the second pair of lyriform pores and there are only two pairs of sternal setae; in $M$. occidentalis, the occurrence of a fourth pair of preanal setae is infraspecific: one or both of the posterior pair may be present; and in most of the species placed by Muma in Galendromus, the posterior pair of preanal setae is variable. Eventually, Cydnodromella Muma also may be considered congeneric with Metaseiulus.

Sublateral setae II are lacking in this genus.

\section{KEY TO CALIFORNIA SPECIES: FEMALES}

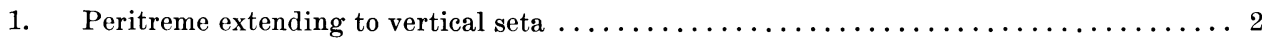

Peritreme extending only to prolateral seta IV ................ (1) occidentalis

$2(1)$. Ventri-anal plate with three pairs of preanal setae $\ldots \ldots \ldots \ldots \ldots \ldots \ldots \ldots \ldots \ldots \ldots$

Ventri-anal plate with four pairs of preanal setae $\ldots \ldots \ldots \ldots \ldots \ldots \ldots \ldots \ldots \ldots$

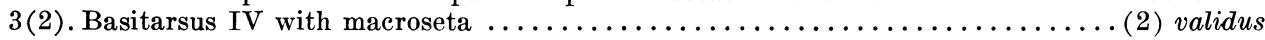

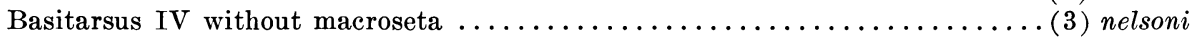

$4(2)$. Opisthosoma with two pairs of ventrolateral setae $\ldots \ldots \ldots \ldots \ldots \ldots \ldots \ldots \ldots \ldots \ldots \ldots$ Opisthosoma with one pair of ventrolateral setae $\ldots \ldots \ldots \ldots \ldots \ldots \ldots \ldots \ldots \ldots \ldots \ldots 7$

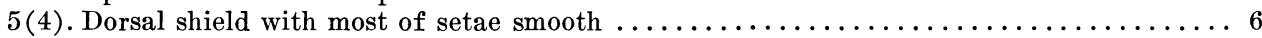
Dorsal shield with all setae pectinate $\ldots \ldots \ldots \ldots \ldots \ldots \ldots \ldots \ldots \ldots \ldots \ldots$ (4) pinnatus

6(5). Postmediolateral setae much shorter than distances between their bases and those of penultimate postlateral setae ............................. pomi

Postmediolateral setae reaching to bases of penultimate postlateral setae ...(6) pomoides

7 (4). Prolateral setae almost as long as the distances between their bases, or slightly longer

(8) flumenis

\section{Metaseiulus occidentalis (Nesbitt), new combination \\ (Fig. 14)}

Typhlodromus occidentalis Nesbitt, 1951, p. 29.

Chant (1960a) separated Metaseiulus occidentalis from $M$. longipilus
(Nesbitt) on the basis of shorter dorsal setae and a shorter peritreme, whereas Nesbitt (1951) had mentioned only differences in setal length. There seem to be variations between populations or individuals as to whether the dorsal 

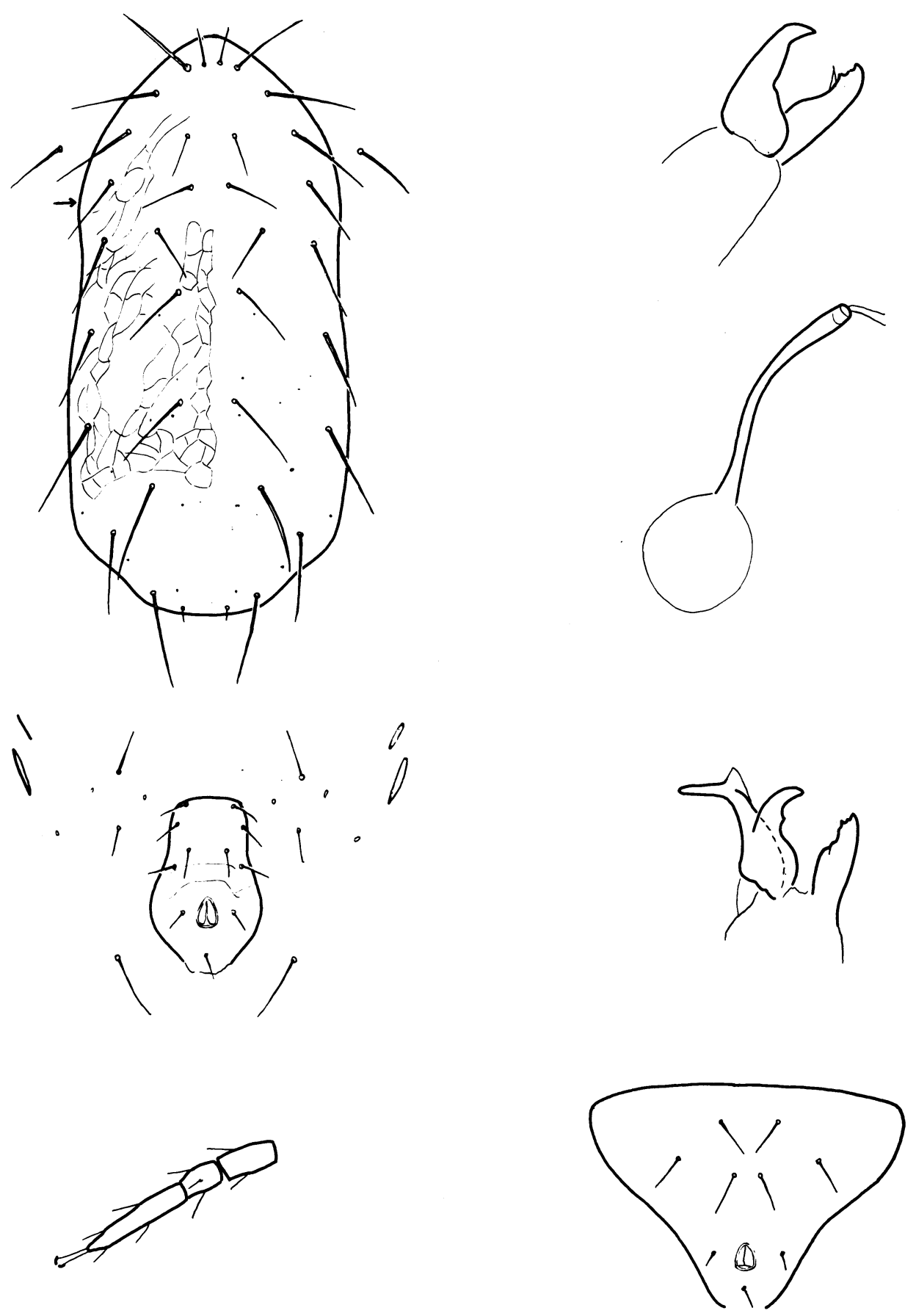

Fig. 14. Metaseiulus occidentalis (Nesbitt). 
setae reach just to the next setal insertions or somewhat beyond. The absolute lengths of setae are comparable between California specimens of $M$. occidentalis and eastern specimens that we determined as $M$. longipilus. In California specimens, the length of the peritreme varies between $25 \mu$ and $42 \mu$. In the few specimens of $M$. longipilus that we measured, it varied from $64 \mu$ to $80 \mu$. However, it is questionable whether $\boldsymbol{M}$. occidentalis and $\boldsymbol{M}$. longipilus are distinct species. In both, the ventri-anal plate may bear three, three and one-half, or four pairs of preanal setae; one or both setae of the posterior pair are those most often lost.

Female. Chelicera with two subapical teeth on fixed digit. Dorsal shield $315 \mu$ long, $216 \mu$ wide, reticulate particularly between mediolateral setae. Vertical and clunal setae relatively short; dorsocentrals I-IV lengthening progressively from $25 \mu$ to $60 \mu$; remaining dorsal setae $48 \mu$ to $65 \mu$, the posterior setae longer. Peritreme not extending forward beyond prolateral seta IV. Ventri-anal plate $60 \mu$ wide, $100 \mu$ long, basically with four pairs of preanal setae. Venter with two pairs of ventrolateral setae. Primary metapodal platelets $14 \mu$ long, $4 \mu$ wide; accessory platelets $8 \mu$ by $3 \mu$. Genital plate $55 \mu$ wide. Posterior margin of sternal plate and the metasternal platelets usually indistinct. Cervix and atrium of spermatheca, combined lengths, $26 \mu$, width $4 \mu$. Basitarsus IV without macroseta.

Male. Ventri-anal plate with three pairs of preanal setae.

\section{COLLECTION DATA}

Alameda County: Berkeley, June 27, 1952 (W. W. Allen). Amador County: Benson and Dondero vineyards, April 16, 1957 (R. O. Schuster, L. M. Smith); Plymouth, September 5, 1958 (R. O. Schuster). Contra Costa County: Walnut Creek, July 2, 1959 (B. E. Pullen). Fresno County: east of Clovis, east of Fresno, and intersection of Highland and Jensen roads,
April 4 and 5, 1957 (R. O. Schuster, L. M. Smith) ; Huron, September 1, 1960 (I. Rammer). KeRN County: Bakersfield, intersection of Road $61 / 2$ and Benicia Road, intersection of 12th and Fargo roads, and northeast of Shafter, April 3 and 4, 1957 (all by R. O. Schuster and L. M. Smith). MEndocino County: Calpella and Redwood Valley, August 29, 1959 (R. O. Schuster, L. M. Smith); Talmage, September 16, 1958 (B. E. Bearden). Monterey County: Salinas, February 9, 1940 (L. M. Smith). Napa County: Calistoga and Mount St. Helena, February 3, 1959 ; Napa, August 2, 1960, and Rutherford, December 11, 1957 (all by S. F. Bailey). Placer County: Loomis, May 22, 1958 (S. F. Bailey). Sacramento County: Isleton, September 3, 1958 (R. O. Schuster). SAN JoAquIN County: Acampo, March 13, and Linden, November 15, 1957 (R. O. Schuster, L. M. Smith) ; Lockeford, August 11, 1956 (L. M. Smith); Lodi; September 22, 1960 (R. O. Schuster); Stockton and Vernalis, April 21 and 23, 1938 (L. M. Smith); Victor, March 13, and near Woodbridge, May 2, 1957 (R. O. Schuster, L. M. Smith). SaN Mateo County: Atherton, November 1, 1958, and Redwood City, September 2, 1957 (R. O. Schuster). Santa Clara County: Coyote, October 6, 1953, and Morgan Hill, September 8, 1952 (W. W. Allen); Mountain View, November, 1950; San Jose, February 18, 1953, and Santa Clara, October 7, 1952 (W. W. Allen). Solano County: Mix Canyon, August 25, 1960 (R. O. Schuster). Sonoma County: Asti, October 22, 1956 (R. O. Schuster, L. M. Smith) ; Fulton, August 15, 1956 (L. M. Smith) ; 2 miles north of Geyserville, October 22, 1956, and 10 miles south of Santa Rosa, April 18, 1957 (R. O. Schuster, L. M. Smith); near Trenton, July 17, 1957 (R. O. Schuster). Stanislaus County: Modesto, April 23, 1957; Salida, September 10, 1959 (A. E. Pritchard); Westley, October 12, 1953 (E. R. Oatman). Yolo County: Davis, September 24, 
1956 (R. O. Schuster) ; Knights Landing, October 25, 1957 (S. F. Bailey). Yuba County: Marysville, May, 1955 (W. Anderson).

Found on Acer negundo, Aesculus californica, Convolvulus, Cynodon dactylon, Fragaria, Gossypium, Juglans, Magnolia, Malus, Phaseolus, Prunus domestica, Quercus, Salix, Sambucus, Umbellularia, and Vitis.

Metaseiulus occidentalis has been found associated with the following prey: Eotetranychus willamettei, Eriophyes vitis, Panonychus ulmi, Steneotarsonemus pallidus, Tetranychus pacificus, and $T$. telarius. It is the species most frequently collected from valley areas of central and northern California. It is an effective predator and may continue to attack although excess prey is only partially consumed. An adult female can eliminate about 100 individuals of Eriophyes vitis during a 24hour period.

\section{Metaseiulus validus (Chant)}

(Fig. 15)

Typhlodromus (Typhlodromus) validus Chant, $1957 a$, p. 290.

Metaseiulus validus (Chant). Muma, 1961, p. 295.

Metaseiulus validus has three pairs of preanal setae on the ventri-anal plate of the female and has moderately long dorsal setae. Basitarsus IV bears a macroseta.

Female. Chelicera with two subapical teeth on fixed digit, one on movable digit. Dorsal shield $385 \mu$ long, $225 \mu$ wide, reticulate. Vertical setae $22 \mu$; dorsocentrals I and II $14 \mu$, III $17 \mu$, IV $21 \mu$; clunals $8 \mu$; prolaterals I $22 \mu$, II $19 \mu$, III $20 \mu$, IV $21 \mu$, V $25 \mu$, VI $28 \mu$; postlaterals I $31 \mu$, II $21 \mu$, III $42 \mu$; promediolaterals $17 \mu$, postmediolaterals $40 \mu$; sublaterals I $21 \mu$; all setae very fine, apparently not serrate. Peritreme extending forward nearly to base of vertical seta. Ventri-anal plate $60 \mu$ wide, $125 \mu$ long, with three pairs of preanal setae but no pores. Only one pair of ventrolateral setae; five pairs of small ventrolateral platelets. Pri- mary metapodal platelets $50 \mu$ long, $4 \mu$ wide; accessory platelets $13 \mu$ by $3 \mu$. Genital plate $65 \mu$ wide. Sternal plate with two pairs of setae, the third pair separate from plate and apparently not on platelets; metasternal platelets small, about twice as long as wide. Cervix and atrium of spermatheca, combined lengths, $20 \mu$. Leg IV with macroseta on basitarsus $38 \mu$.

Male. Spermatodactyl essentially as in M. mcgregori (Fig. 19). Ventri-anal plate with four pairs of preanal setae.

\section{COLLECTION DATA}

Contra Costa County: Mount Diablo, August 22, 1959 (B. E. Pullen). Inyo County: Big Pine, May 24, 1951 (A. E. Pritchard). Riverside County: San Jacinto, September 9, 1958 (C. D. Brickhill). San Bernardino County: near Camp Baldy, June 7, 1958 (C. D. Brickhill). Siskiyou County: Dunsmuir, August 19, 1958 (C. D. Brickhill). Tehama County: near Franklin, August 30, 1960 (R. O. Schuster). (Described from British Columbia; found also in Arizona and Nevada.)

Found on Abies, Juniperus, Pinus, and Rhus diversiloba.

\section{Metaseiulus nelsoni (Chant)}

Typhlodromus (Typhlodromus) nelsoni Chant, $1960 a$, p. 56.

Metaseiulus nelsoni (Chant). Muma, 1961, p. 295.

The characters of Metaseiulus nelsoni by which Chant distinguished it from $M$. validus are shorter dorsal setae, three rather than five pairs of tiny ventrolateral platelets, and no macroseta on leg IV. We have not seen this species.

\section{COLLECTION DATA}

Tulare County: Camp Nelson (holotype).

Found on cedar.

\section{Metaseiulus pinnatus, new species (Fig. 16)}

This species closely resembles Metaseiulus carinulatus (DeLeon) but dif- 

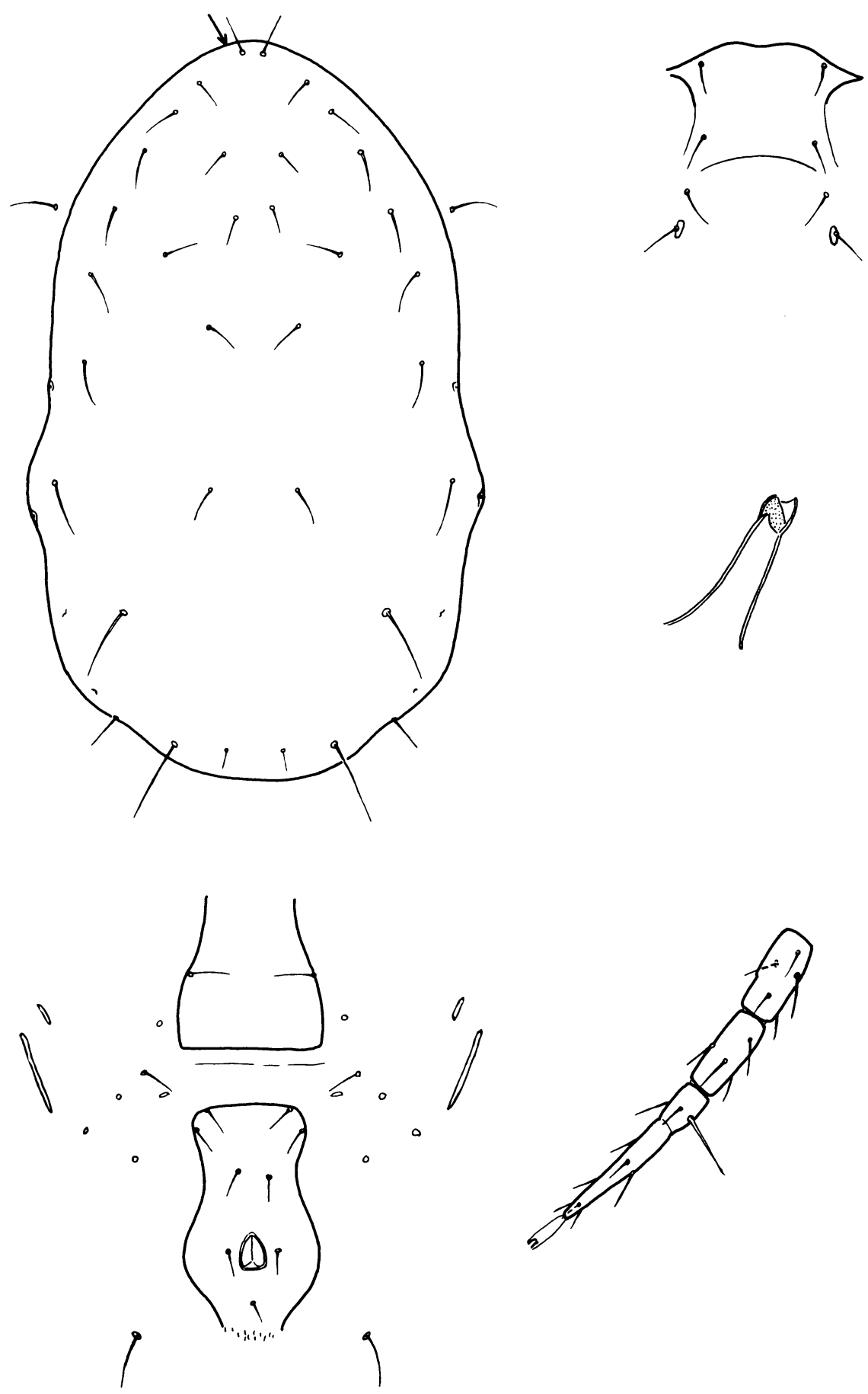

Fig. 15. Metaseiulus validus (Chant). 

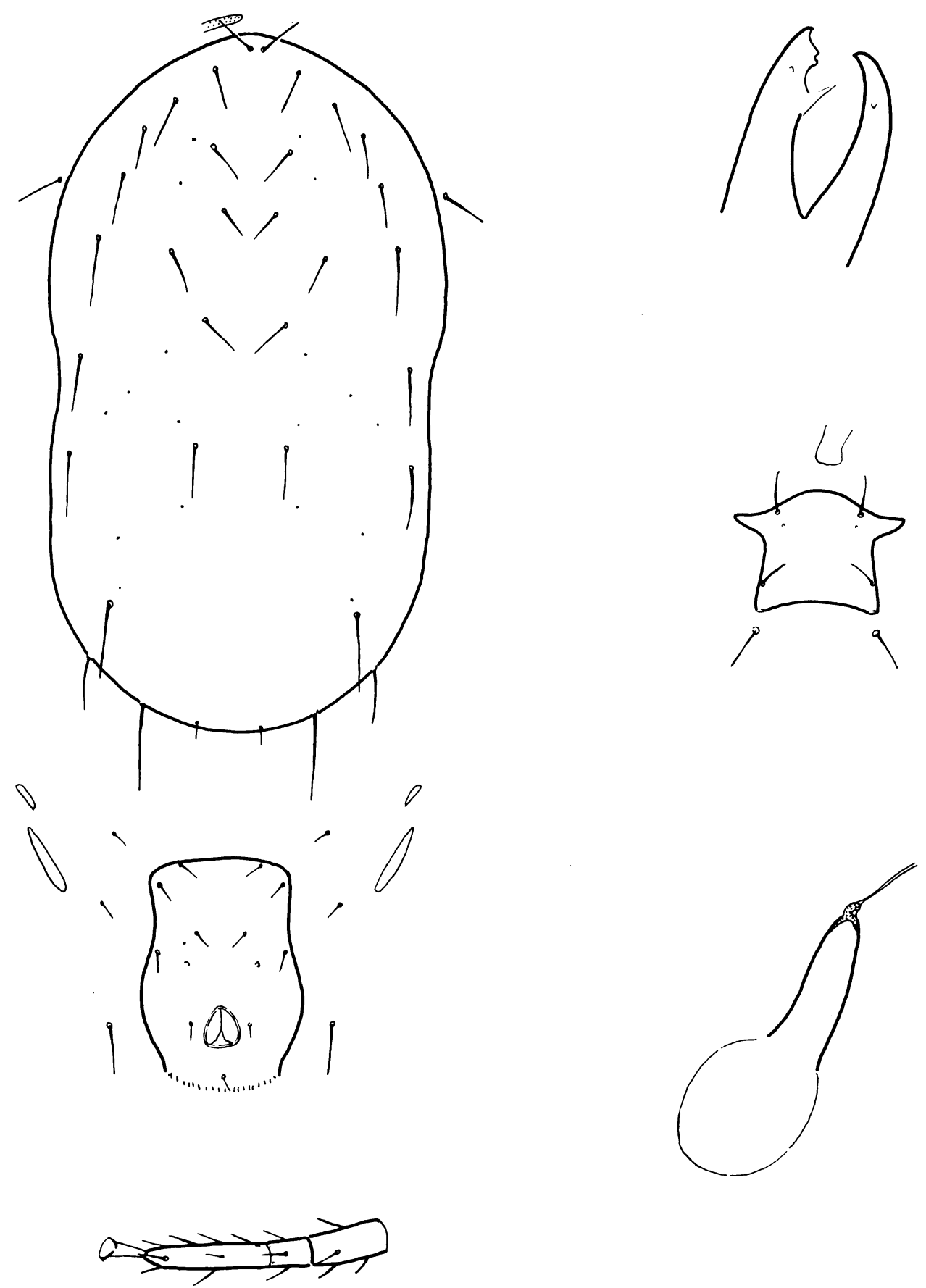

Fig. 16. Metaseiulus pinnatus, new species. 

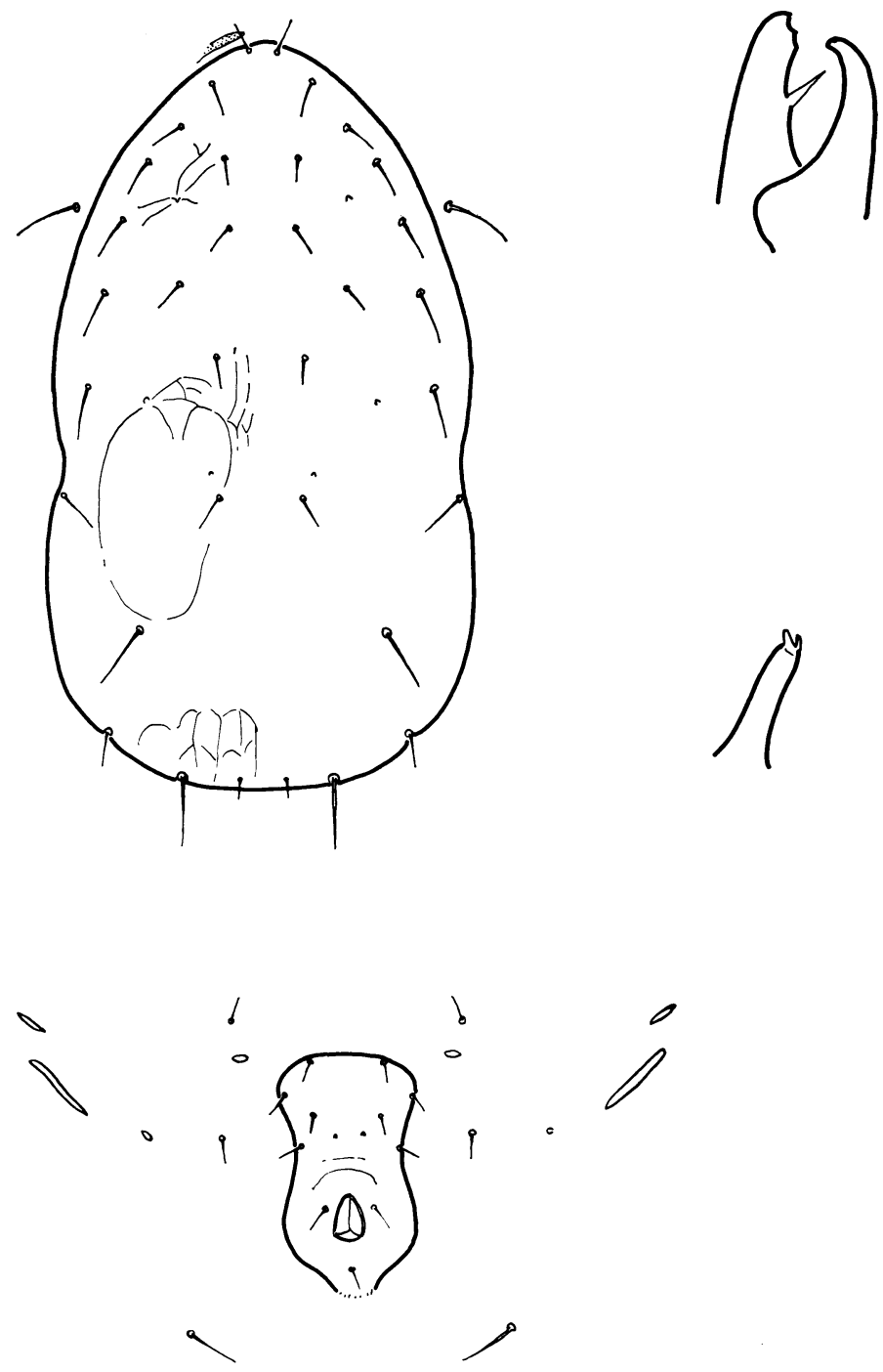

Fig. 17. Metaseiulus pomi (Parrott).

fers in that it is $100 \mu$ longer, has dorsocentral setae III and IV and postlateral setae II serrate, and has two pairs of ventrolateral setae.

Female. Chelicera with two subapical teeth on fixed digit, possibly one on movable digit. Dorsal shield $400 \mu$ long, $250 \mu$ wide, reticulate except in areas of the dorsal rectangle and between the postmediolateral setae. Vertical setae $20 \mu$; dorsocentrals I $17 \mu$, II $18 \mu$, III $23 \mu$, IV $27 \mu$; clunals $13 \mu$; prolaterals I $28 \mu$, II $25 \mu$, III $28 \mu$, IV and V $32 \mu$, VI
$37 \mu$; postlaterals I $39 \mu$, II $29 \mu$, III $50 \mu$; promediolaterals $19 \mu$, postmediolaterals $46 \mu$; sublaterals I $28 \mu$; all of the larger setae serrate. Peritreme extending forward to base of vertical seta. Ventrianal plate $85 \mu$ wide, $130 \mu$ long, widest across posterior third, with four pairs of preanal setae and with a pair of pores slightly behind and mediad to the fourth setae. Venter with two pairs of ventrolateral setae. Primary metapodal platelets $34 \mu$ long, $4 \mu$ wide; accessory platelets variable, usually $14 \mu$ 
by $3 \mu$. Genital plate $64 \mu$ wide. Sternal plate with two pairs of setae, the third pair separate from the plate; metasternal platelets minute. Spermatheca with cervix $22 \mu$ long, atrium $4 \mu$. Leg IV lacking macrosetae.

Male. Unknown.

Holotype. Female, Napa, NAPA County, September 30, 1958 (R. O. Schuster), from an abandoned prune orchard; type no. 2780 in the U. S. National Museum.

Paratypes. One female, data same as for holotype; three females, Napa, Napa County, September 11, October 28, and December 2, 1958 (J. J. Skelsey); and one female, Bolinas, MariN County, April 7, 1960 (R.O. Schuster).

\section{Metaseiulus pomi (Parrott), new combination}

(Fig. 17)

Seius pomi Parrott, 1906, p. 302.

Iphidulus pomi (Parrott). Garman, 1948, p. 13. Typhlodromus pomi (Parrott). Nesbitt, 1951, p. 28.

The taxonomic status of the California population is somewhat confused. Illustrations of the ventri-anal plate by Nesbitt (1951) and by Chant (1960a) show no preanal pores. Cunliffe and Baker (1953) show the plate as proportionately longer and with pores. This is the type found in California. The California form usually has short dorsal setae, which agree with setae on specimens from the eastern United States better than with those in the illustrations by Nesbitt or by Chant.

Female. Chelicera with a large subapical tooth on fixed digit, movable digit smooth. Dorsal shield $312 \mu$ long, $170 \mu$ wide, reticulate. Vertical setae $17 \mu$; dorsocentrals I and II $13 \mu$, III $14 \mu$, IV $16 \mu$; clunals $8 \mu$; prolaterals I, II, and IV $17 \mu$, III, V, and VI $18 \mu$; postlaterals I $21 \mu$, II $14 \mu$, III $29 \mu$; mediolaterals I $14 \mu$, II $25 \mu$; sublaterals I $21 \mu$; postlaterals III and mediolaterals II serrate. Peritreme extending to base of vertical seta. Ventri-anal plate $52 \mu$ wide, $100 \mu$ long, with four pairs of preanal setae and with a pair of pores behind and mediad to the third setae. Two pairs of ventrolateral setae and two to four pairs of small platelets surrounding ventri-anal plate. Primary metapodal platelets $31 \mu$ long, $4 \mu$ wide; accessory platelets $13 \mu$ by $3 \mu$. Genital plate $54 \mu$ wide. Third pair of sternal setae separate from plate; metasternal platelets small, longer than wide. Cervix and atrium of spermatheca, combined lengths, $15 \mu$. Longest seta of leg IV basitarsus $16 \mu$.

Male. Dorsal shield $235 \mu$ long, $135 \mu$ wide. Ventri-anal plate with four pairs of preanal setae.

\section{COLLECTION DATA}

Contra Costa County: Antioch, August 9, 1952 (W. C. Bentinck). YoLo County: Davis, June 1 and July 1, 1957 (R. O. Schuster).

Taken from eriophyid galls on English walnut and from grass.

\section{Metaseiulus pomoides, new species}

(Fig. 18)

Metaseiulus pomoides is similar to $M$. pomi but has very much longer dorsal setae, except for prolaterals II, postlaterals II, sublaterals I, and clunals.

Female. Chelicera with subapical tooth on fixed digit, one on movable digit. Dorsal shield $312 \mu$ long, $175 \mu$ wide. Vertical setae $23 \mu$; dorsocentrals I and II $20 \mu$, III $28 \mu$, IV $32 \mu$; clunals $9 \mu$; prolaterals I $27 \mu$, II $24 \mu$, III $33 \mu$, IV $35 \mu, \mathrm{V} 40 \mu$, VI $41 \mu$; postlaterals I $45 \mu$, II $19 \mu$, III $66 \mu$; promediolaterals $23 \mu$, postmediolaterals $51 \mu$; sublaterals I $25 \mu$; postlaterals III and postmediolaterals distinctly serrate. Peritreme extending forward to base of vertical seta. Ventri-anal plate $64 \mu$ wide, $105 \mu$ long, with four pairs of preanal setae and with a pair of pores, between and behind the third setae. Two pairs of ventrolateral setae and three pairs of small platelets laterad to ventri-anal plate. Primary metapodal platelets $29 \mu$ long, $5 \mu$ wide; accessory platelets $12 \mu$ by $3 \mu$. A small platelet laterad to each 

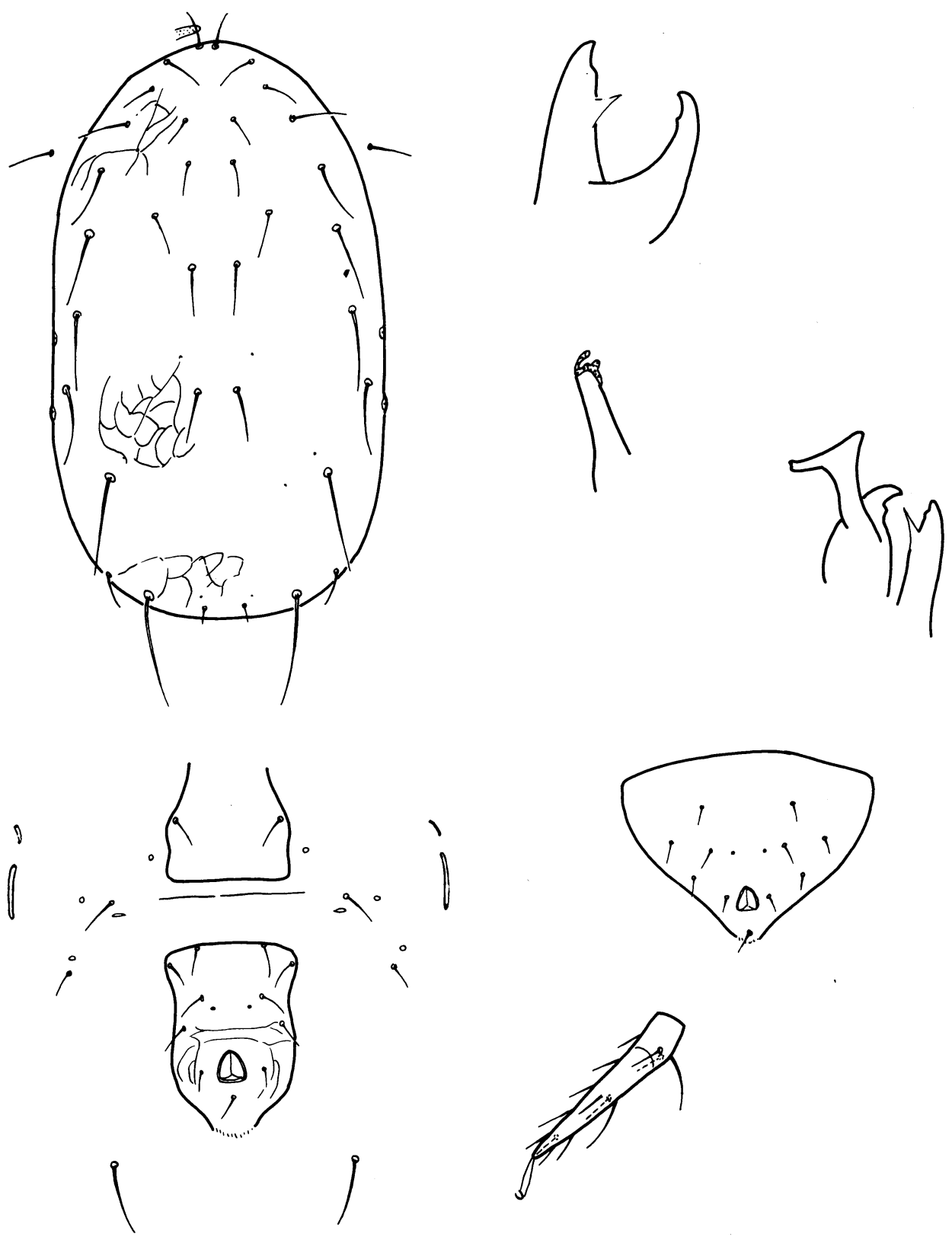

Fig. 18. Metaseiulus pomoides, new species.

postlateral margin of the genital plate. Genital plate $60 \mu$ wide. Third pair of sternal setae separate from plate; metasternal platelets small, longer than wide. Cervix and atrium of spermatheca, combined lengths, $24 \mu$. Leg IV with macroseta on basitarsus $34 \mu$.

Male. Ventri-anal plate with four pairs of preanal setae and a pair of pores.

Holotype. Female, Davis, Youo County, August 20, 1959 (R. O. Schuster), on foliage of white alder; type no. 2781 in the U. S. National Museum.

Paratypes. Two females, data same 
as for holotype; five females, eight males, Davis, Yolo Countr, September 30, 1945 (L. M. Smith), on grapevine, feeding on Eriophyes vitis; seven females, one male, Davis, October 4, 1956 (R. O. Schuster), on Acer negundo.

Additional records. Butte County: Chico, September 4, 1958 (R. O. Schuster, L. M. Smith). Yolo County: Willowbank, August 23, 1958 (L. M. Smith), feeding on tetranychids. Southwest Research Station, Chiricahua
Mountains, Arizona, August 6, 1958 (R. O. Schuster).

\section{Metaseiulus mcgregori (Chant), new combination}

(Fig. 19)

Typhlodromus new species, Cunliffe and Baker, 1953, p. 21.

Typhlodromus (Typhlodromus) megregori Chant, $1960 a$, p. 57.

Chant (1960a) distinguished the two closely related species Metaseiulus mcgregori and $M$. flumenis by the
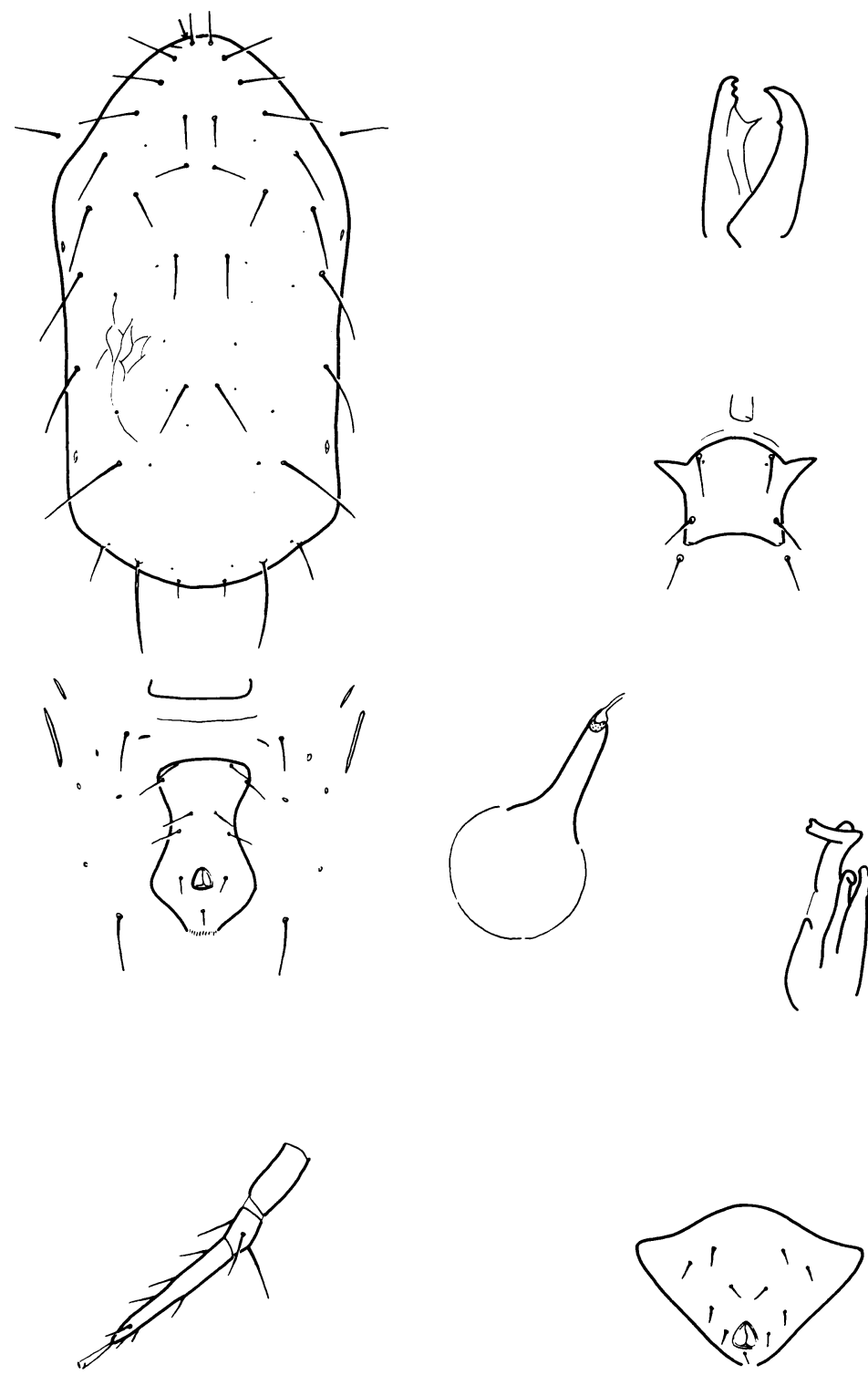

Fig. 19. Metaseiulus mcgregori (Chant). 
lengths of their prolateral setae. In $M$. mcgregori, these setae are more slender and are usually longer than the distances between their bases. This form occurs in the coast range and valley areas of California. The dorsal setae vary in length and may be asymmetrical; in one individual, one of the postmediolateral pair measured $30 \mu$ and the other $50 \mu$. Ordinarily, the variation in length of prolateral setae is about $5 \mu$. The numbers and placement of the preanal setae are unstable: frequently there are four setae on one side and three on the other; on occasional specimens the insertions of the posterior pair are transverse instead of oblique.

Female. Chelicera with two subapical teeth on fixed digit, one on movable digit. Dorsal shield $335 \mu$ long, $175 \mu$ wide, faintly reticulate laterally. Vertical setae $21 \mu$; dorsocentrals I and II $17 \mu$, III $29 \mu$, IV $34 \mu$; clunals $8 \mu$; prolaterals I $29 \mu$, II $25 \mu$, III and IV $34 \mu$, V $40 \mu$, VI $45 \mu$; postlaterals I $46 \mu$, II $21 \mu$, III $57 \mu$; promediolaterals $22 \mu$, postmediolaterals $50 \mu$; sublaterals I $29 \mu$; postlaterals III and sometimes postmediolaterals serrate. Peritreme extending forward to base of vertical seta. Ventri-anal plate $62 \mu$ wide, $110 \mu$ long, with four pairs of preanal setae. One pair of ventrolateral setae and a variable number of small platelets surrounding the ventri-anal plate.Primary metapodal platelets $35 \mu$ long, $4 \mu$ wide; accessory platelets $12 \mu$ by $3 \mu$. Genital plate $64 \mu$ wide. Third pair of sternal setae separate from plate; metasternal platelets small. Cervix and atrium of spermatheca, combined lengths, about $19 \mu$. Leg IV with macroseta on basitarsus $40 \mu$.

Male. Ventri-anal plate with four pairs of preanal setae.

\section{COLLECTION DATA}

Alameda County: Livermore, May 15, 1959 (A. N. Kasimatis). Amador County: near Plymouth, September 5, 1958. Butre County: Chico, September 4, 1958 (R. O. Schuster). Contra
Costa County: north of Antioch, February 15, 1957 (R. O. Schuster, L. M. Smith) ; Mount Diablo, August 22, 1959 (B. Pullen). EL Dorado County: Placerville, May 16, 1959 (H. H. Keifer). Fresno County: Herndon, March 15, and Orange Cove, May 3, 1956 (C. E. Kennett); intersection of Shaw and Lola roads, April 5, 1957 (R. O. Schuster). Kings County: intersection of 13th and Elder roads, April 3, 1957 (R. O. Schuster, L. M. Smith). Lake County: Middletown, September 25, 1959 (A. N. Kasimatis). Madera County: Madera, May 22, 1952. MeNDocino County: Redwood Valley and Talmage, July 29, 1959 (R. O. Schuster, L. M. Smith). Monterey County: Monterey, May 25, 1951 (R. N. Weir). NaPA County: Napa, December 22, 1959 (S. F. Bailey, R. O. Schuster). Placer County: Roseville, July 23, 1959 (R. O. Schuster, L. M. Smith). Riverside County: Beaumont, Palm Springs, and White Water, July 7, 1958 (C. D. Brickhill). Sacramento County: Nimbus, June 4, 1955 (H. H. Keifer). SAN Joaquin County: Lockeford, September 6, 1957 (L. M. Smith); Lodi, September 4, 1959 (R. O. Schuster, L. M. Smith). San Mateo County: San Mateo, June 30, 1959 (A. E. Pritchard). Siskiyou County: 12 miles south of Callahan, July 25, 1960 (J. Campbell). Sonoma County: Cloverdale, July 19, 1939 (L. M. Smith). Tulare County: 2 miles west of Springville, May 13, 1959 (L. M. Smith). Yolo County: Davis, September 3, 1954 (L. M. Smith) and July 23, 1957 (R. O. Schuster) ; 3 miles north of Rumsey, July 29, 1959. (Occurs also in Arizona, Nevada, New Mexico, and Washington.)

Taken from Acer negundo californicum, Baccharis pilularis, Ficus, Iris, Juglans, Olea, Phoradendron, Picea, Pinus, Platanus, Quercus dumosa, Umbellularia californicus, and Vitis, and from a Neotoma nest. Prey includes Brevipalpus keiferi, Eotetranychus willamettei, the bud strain and the 
erinose strain of Eriophyes vitis, other eriophyids, and Tetranychus pacificus.

\section{Metaseiulus flumenis (Chant), new combination}

Typhlodromus (Typhlodromus) flumenis Chant, $1957 a$, p. 290.

Metaseiulus flumenis differs from $M$. mcgregori in that the prolateral setae are shorter. It occurs in California at relatively high altitudes.

Female. Dorsal shield $355 \mu$ long, $200 \mu$ wide, reticulate in a pattern similar to that of $M$. megregori. Vertical setae $25 \mu$; dorsocentrals I-III $17 \mu$, IV $25 \mu$; clunals $8 \mu$; prolaterals I $25 \mu$, II $21 \mu$, III $22 \mu$, IV $26 \mu, \mathrm{V} 31 \mu$, VI $40 \mu$; postlaterals I $37 \mu$, II $22 \mu$, III $43 \mu$; promediolaterals $17 \mu$, postmediolaterals $38 \mu$, sublaterals I $22 \mu$; postlaterals III faintly serrate. Peritreme extending forward to base of vertical seta. Ventrianal plate $62 \mu$ wide, $109 \mu$ long, with four pairs of preanal setae, no pores. Only one pair of ventrolateral setae. Primary metapodal platelets $37 \mu$ long, $4 \mu$ wide; accessory platelets $11 \mu$ by $3 \mu$. Three pairs of small platelets between ventri-anal plate and metapodal platelets and an additional pair at postlateral margin of genital plate. Genital plate $67 \mu$ wide. Sternal plate with two pairs of setae, the third pair separate from plate. Metasternal platelets small, about twice as long as wide. Cervix and atrium of spermatheca, combined lengths, about $22 \mu$. Leg IV with macroseta of basitarsus $34 \mu$.

Male. Unknown.

\section{COLLECTION DATA}

Plumas County: near Quincy, July 21, 1958 (C. D. Brickhill). Shasta County: Burney, July 19, 1958 (C. D. Brickhill).

Found on Cedrus and Pinus.

\section{TRIBE AMBLYSEIINI MUMA}

Amblyseiinae Muma, 1961, p. 273.

\section{KEY TO GENERA OF THE WORLD: FEMALES}

1. Postscutum with postmediolateral setae more or less in a transverse line with postlateral setae III $\ldots \ldots \ldots \ldots \ldots \ldots \ldots \ldots \ldots \ldots \ldots \ldots \ldots \ldots \ldots \ldots \ldots \ldots \ldots$

Postscutum with postmediolateral setae not in a transverse line with any setae;

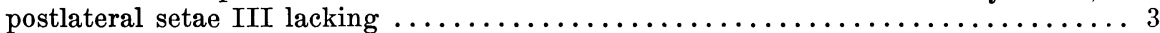

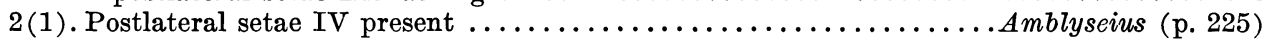

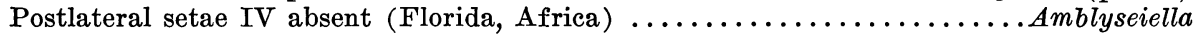

$3(1)$. Two pairs of postlateral setae caudad to postmediolateral setae . . . . . . . . . . . 4

One pair of postlateral setae caudad to postmediolateral setae $\ldots \ldots \ldots \ldots \ldots \ldots \ldots \ldots$

4(3). Two pairs of postlateral setae anterior to postmediolateral setae (Europe, eastern

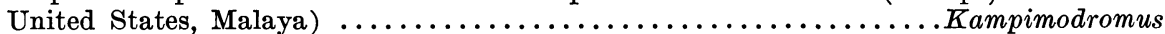

One pair of postlateral setae anterior to postmediolateral setae $\ldots \ldots \ldots \ldots \ldots \ldots \ldots \ldots$

5 (4). Dorsocentral setae III much shorter than some of the lateral setae (eastern United

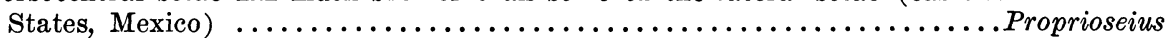
Dorsocentral setae III and prolateral setae IV longer than other prolateral setae

6(3). Two pairs of postlateral setae anterior to postmediolateral setae (Africa) ....Asperoseius One pair of postlateral setae anterior to postmediolateral setae (Africa) ......Ptenoseius

\section{Genus Amblyseius Berlese}

Amblyseius Berlese, 1914, p. 143.

Amblyseius (Seiopsis), Berlese, 1923, p. 255.

Amblyseius (Amblyseiopsis), Garman, 1948, p. 17.

Amblyseiopsis Garman. Muma, 1955, p. 264.

Typhlodromus (Amblyseius), Chant, 1957b, p. 530.

Phyllodromus De Leon, 1959b, p. 260.

Typhlodromus (Typhlodromopsis), De Leon, $1959 c$, p. 113. 


\section{CALIFORNIA SPECIES, KEY TO SECTIONS: FEMALES}

1. One or more of the prolateral setae at least three times* as long as dorsocentral setae

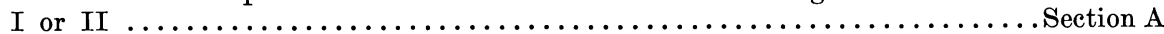

None of the prolateral setae three times as long as dorsocentral setae I or II .... Section B

\section{CALIFORNIA SPECIES, KEY TO SECTION A: FEMALES}

1. Prolateral setae II and III small, subequal to dorsocentral setae I and II ....... Prolateral setae II, or II and III, much longer than dorsocentral setae I and II . . . 7

2(1). Postmediolateral pair of setae developed as macrosetae ................. 3

Postmediolateral pair of setae not developed as macrosetae, but subequal to pro-

lateral setae II and III and to dorsocentral setae ............... (1) limonicus

$3(2)$. Venter with two pairs of normal metapodal platelets $\ldots \ldots \ldots \ldots \ldots \ldots \ldots \ldots \ldots \ldots \ldots$

Venter with a single, large pair of metapodal platelets .............. (3) lecanis

4(3). Cervix of spermatheca much longer than its greatest width (i.e., width at base) .... 5

Cervix of spermatheca not longer than its greatest width .............. (4) elongatus

$5(4)$. Chelicera of normal size, the apices of the digits nearly meeting when closed $\ldots \ldots \ldots 6$

Chelicera large, the apex of movable digit meeting fixed digit at about half its

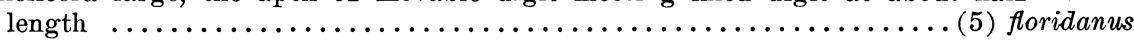

6(5). Ventri-anal plate nearly as long as wide ..................... 6 ) schusteri

Ventri-anal plate distinctly longer than wide $\ldots \ldots \ldots \ldots \ldots \ldots \ldots \ldots \ldots \ldots \ldots \ldots \ldots \ldots$ (7) largoensis

$7(1)$. Prolateral setae II shorter than III $\ldots \ldots \ldots \ldots \ldots \ldots \ldots \ldots \ldots \ldots \ldots \ldots \ldots \ldots \ldots$

Prolateral setae II equal in length to III, or longer $\ldots \ldots \ldots \ldots \ldots \ldots \ldots \ldots \ldots \ldots$

8(7). Postmediolateral setae sometimes shorter than postlateral setae III, never twice as

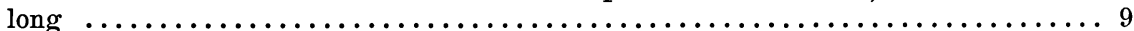

Postmediolateral setae more than twice as long as postlateral setae III .........10

$9(8)$. Ventri-anal plate narrower than genital plate ..................... (2) hibisci

Ventri-anal plate wider than genital plate .................... (8) palustris

10(8). Postlateral setae II developed as macrosetae $\ldots \ldots \ldots \ldots \ldots \ldots \ldots \ldots \ldots \ldots \ldots \ldots \ldots 11$

Postlateral setae II not developed as macrosetae ................. (9) similoides

11(10). Cervix of spermatheca less than twice as long as its greatest width; prolateral setae IV more than twice the length of III ..................... 10) chorites

Cervix of spermatheca more than twice as long as its greatest width; prolateral setae IV not more than twice the length of III ................. (11) ablusus

12(7). Postlateral setae II not developed as macrosetae $\ldots \ldots \ldots \ldots \ldots \ldots \ldots \ldots \ldots \ldots \ldots \ldots$

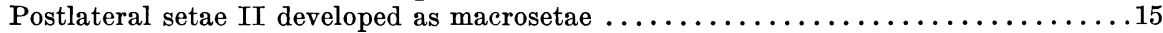

13 (12). Cervix of spermatheca more than twice as long as its greatest width .............

Cervix of spermatheca not longer than its greatest width ............. (12) asetus

14(13). Postmediolateral setae shorter than postlateral setae V; preanal pores well caudad to preanal setae $\ldots \ldots \ldots \ldots \ldots \ldots \ldots \ldots \ldots \ldots \ldots \ldots \ldots \ldots \ldots \ldots \ldots \ldots \ldots \ldots \ldots$ (13) lindquisti

Postmediolateral setae longer than postlateral setae V; preanal pores nearly in

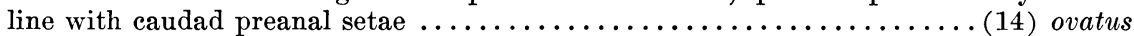

15 (12). Postlateral setae II approximately twice the length of postlateral setae I . . . . . 16

Postlateral setae II many times longer than $\mathrm{I} \ldots \ldots \ldots \ldots \ldots \ldots \ldots \ldots \ldots \ldots \ldots \ldots$

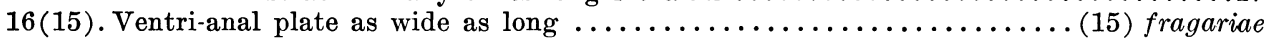

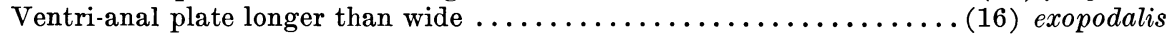

17 (15). Prolateral setae II and III subequal in length ................. (17) newelli

Prolateral setae II about three times the length of III ........... (18) neomexicanus

\section{CALIFORNIA SPECIES, KEY TO SECTION B: FEMALES}

1. Postlateral setae I reaching beyond insertions of postlateral setae II .........2

Postlateral setae I not long enough to reach insertions of postlateral setae II....... 3

2(1). Dorsum with about eight pairs of pores in postscutum; pores of ventri-anal plate

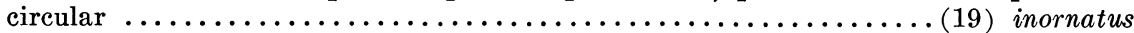

Dorsum with three or four pairs of pores in postscutum; pores of ventri-anal plate

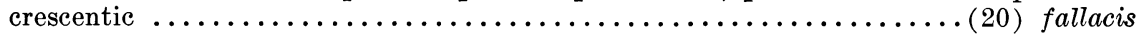

$3(1)$. Cervix of spermatheca approximately four times as long as its greatest width (i.e., width at base $) \ldots \ldots \ldots \ldots \ldots \ldots \ldots \ldots \ldots \ldots \ldots \ldots \ldots \ldots \ldots \ldots \ldots \ldots \ldots$

Cervix of spermatheca rarely more than two, never three times as long as its greatest

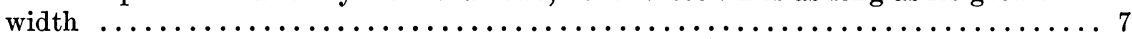

* In many of the California specimens of $A$. hibisci, the ratio may be as low as $2.8: 1$. 
4(3). Atrium of spermatheca large; basitarsus of leg IV with macroseta ......... 5 Atrium of spermatheca very small; basitarsus of leg IV without macroseta

(21) desertus

5(4). Atrium of spermatheca not distinctly constricted before joining cervix ........6 6 Atrium of spermatheca separated from cervix by a distinct constriction. . (22) aurescens

6(5). Dorsal setae thick; macrosetae of basitarsi IV not longer than postmediolateral

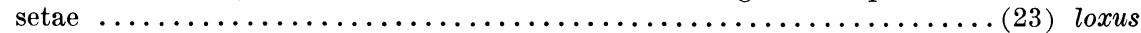

Dorsal setae very fine; macrosetae of basitarsi IV much longer than postmedio-

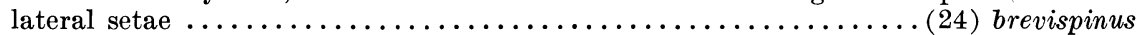

$7(3)$. One or more of the dorsocentral setae subequal to vertical setae or slightly longer... 8 All dorsocentral setae definitely shorter than vertical setae................14

8(7). Atrium of spermatheca large, conspicuous; cervix tapering, seldom rounded at apex... 9

Atrium of spermatheca small but definitely constricted at union with cervix; cervix

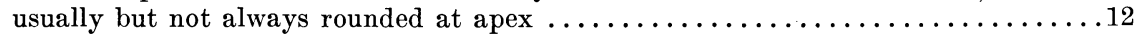

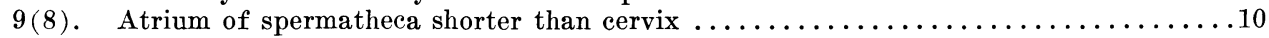

Atrium of spermatheca as long as cervix .................... (26) vallis

$10(9)$. Atrium of spermatheca separated from cervix by a long, well-defined constriction;

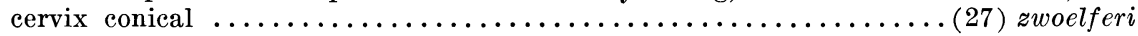

Atrium of spermatheca less conspicuously separated from cervix; cervix tapering

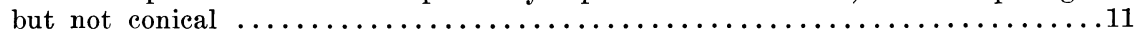

11(10). Postmediolateral setae long enough to reach pores associated with postlateral setae IV; distance separating pores of ventri-anal plate same as that separating

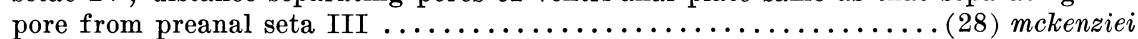

Postmediolateral setae not reaching to pores associated with postlateral setae IV; distance separating pores of ventri-anal plate three times the distance separating

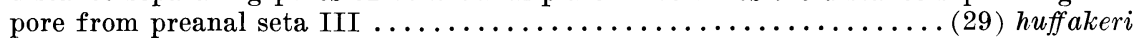

12(8). Ventri-anal plate with large crescentic pores ................ (30) californicus

Ventri-anal plate with pores circular or obsolete $\ldots \ldots \ldots \ldots \ldots \ldots \ldots \ldots \ldots \ldots \ldots$

13(12). Postlateral setae IV only half as long as postmediolateral setae ........... (32) tabis

Postlateral setae IV more nearly subequal to postmediolateral setae..... (33) cucumeris

14(7). Postmediolateral setae nearly four times as long as postlateral setae III... (25) kennetti Postmediolateral setae only slightly longer than postlateral setae III.....(31) scyphus

\section{Amblyseius limonicus Garman and McGregor}

(Fig. 20)

Amblyseius limonicus Garman and McGregor, 1956, p. 11.

Typhlodromus (Amblyseius) limonicus (Garman and McGregor). Chant, 1960a, p. 96.

Amblyseius limonicus differs from the other Amblyseius in California by its short postmediolateral setae and by the slender ventri-anal plate of the female.

Female. Fixed digit of chelicera with about eight teeth, movable digit with two or three. Dorsal shield $375 \mu$ long, $260 \mu$ wide, with four pairs of dorsocentral setae. Vertical setae $34 \mu$; dorsocentrals I-III $8 \mu$, IV $10 \mu$; clunals $8 \mu$; prolaterals I $50 \mu$, II and III $10 \mu$, IV $72 \mu$; postlaterals I $10 \mu$, II and III $14 \mu$, IV $11 \mu$, V $62 \mu$; promediolaterals $8 \mu$, postmediolaterals $10 \mu$; sublaterals I $17 \mu$, II $8 \mu$; postlateral setae $\mathrm{V}$ weakly pectinate. Peritreme extending to base of pro- lateral I. Ventri-anal plate $78 \mu$ wide, $120 \mu$ long, with three pairs of preanal setae and a pair of irregular pores. Primary metapodal platelets $28 \mu$ long, $7 \mu$ wide; accessory platelets nearly obsolete, about $3 \mu$ long. Genital plate $105 \mu$ wide. Metasternal platelets small, not easily seen with ordinary-light microscope. Cervix of spermatheca slender, $34 \mu$ long. Leg IV with macroseta on basitarsus $105 \mu$, on tibia $62 \mu$, on genu $80 \mu$.

Male. Dorsal shield $300 \mu$ long, $200 \mu$ wide. Ventri-anal plate with three pairs of preanal setae and a pair of pores.

\section{COLLECTION DATA}

Riverside County: Corona (holotype). San Mateo County: near Atherton (R. O. Schuster). Sonoma Countr: 10 miles south of Santa Rosa, April 18, and 1 mile south of Trenton, September 2, 1957 (R. O. Schuster, L. M. Smith). (Recorded from Florida by Chant (1960a).) 

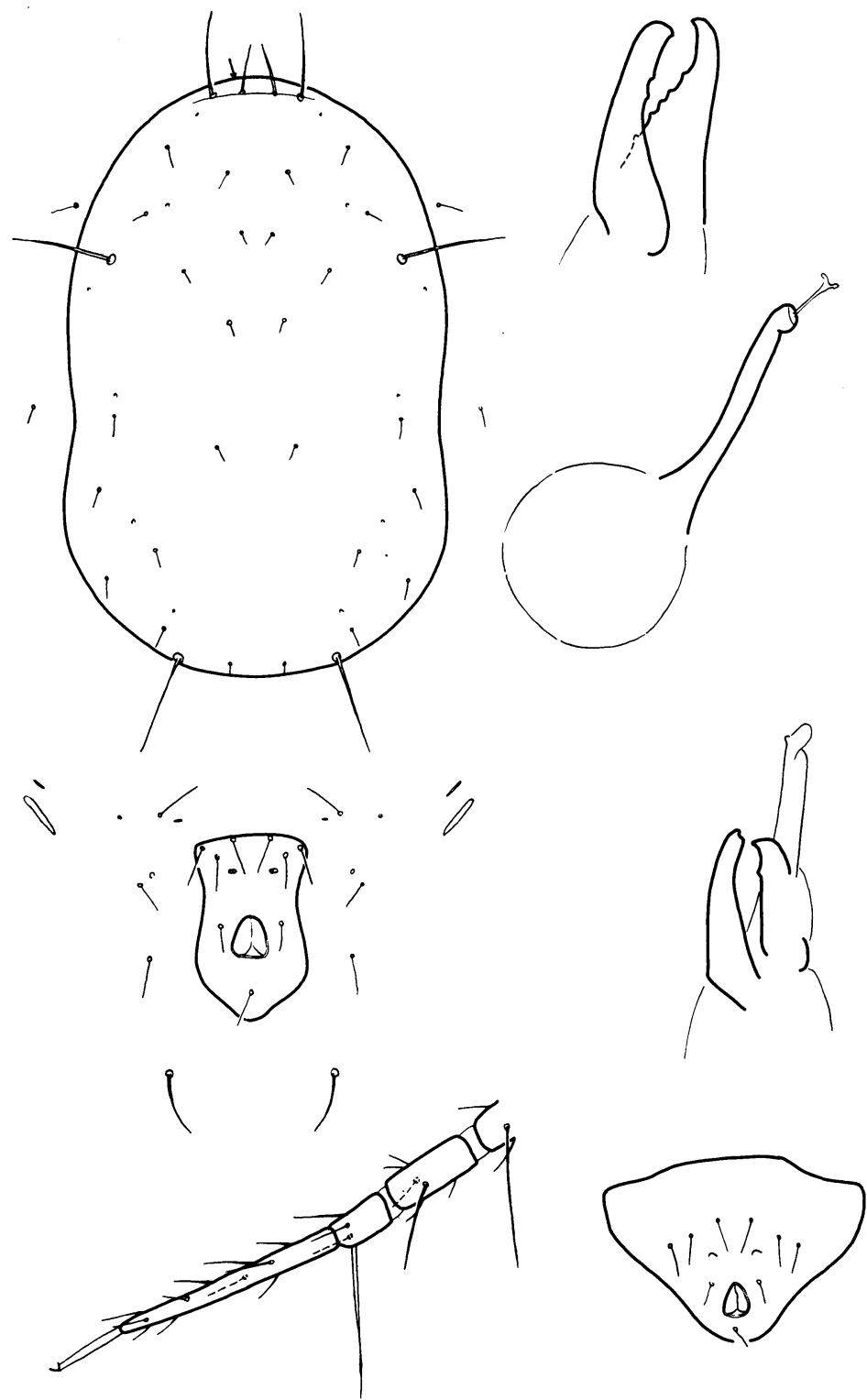

Fig. 20. Amblyseius limonicus Garman and McGregor. Leg IV shows macrosetae on tibia and genu as well as on basitarsus.

Found on foliage of lemon and of Amblyseius hibisci. The setae are magnolia.

\section{Amblyseius hibisci (Chant)}

(Fig. 21)

Typhlodromus (Amblyseius) hibisci Chant, $1960 a$, p. 68.

shorter than those of the described form from Mexico, but they are considerably longer than those of $A$. mesembrinus (Dean). The cervix of the spermatheca is long and uniformly thin-quite unAmblyseius (Typhlodromalus) hibisci(Chant). Muma, 1961, p. 288.

Our California species appears to be like that of $A$. finlandicus (Oudemans), in which the cervix is broad basally and tapers to a large atrium. In many other 

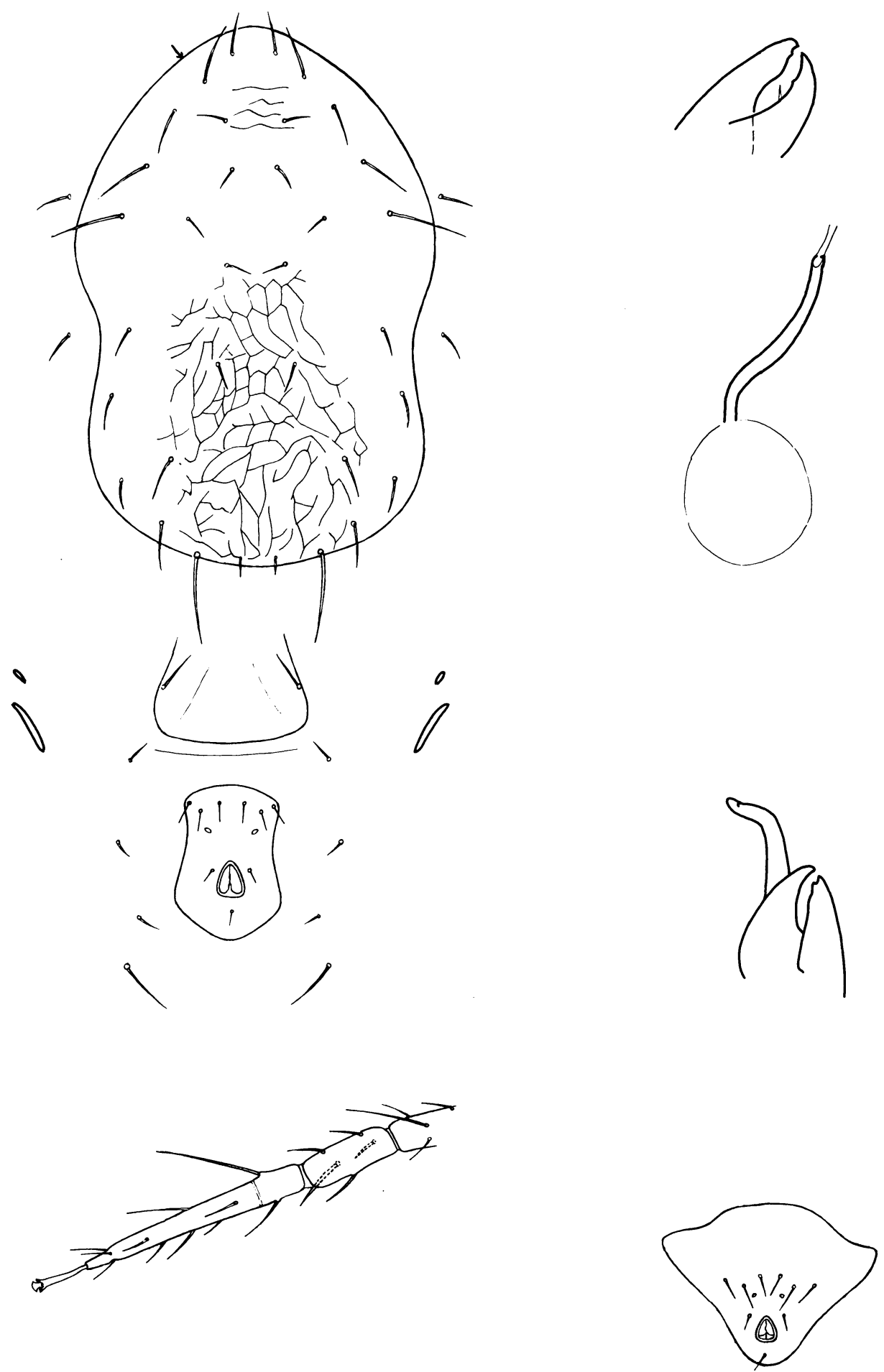

Fig. 21. Amblyseius hibisci (Chant). 
characters, our species resembles either of these two.

Female. Chelicera $25 \mu$ long, with about three small subapical teeth on the fixed digit and one on the movable digit. Dorsal shield $315 \mu$ long, $210 \mu$ wide, with four pairs of dorsocentral setae. Vertical setae $28 \mu$; dorsocentrals I-III $17 \mu$, IV $19 \mu$; clunals $8 \mu$; prolaterals I $36 \mu$, II $28 \mu$, III $34 \mu$, IV $48 \mu$; postlaterals I $16 \mu$, II and III $28 \mu$, IV $34 \mu, \mathrm{V} 60 \mu$; promediolaterals $17 \mu$, postmediolaterals $25 \mu$; sublaterals I and II $16 \mu$; all setae simple except postlaterals $\mathrm{V}$, which are weakly serrate. Peritreme extending to base of prolateral I. Ventri-anal plate $70 \mu$ wide, $110 \mu$ long, with three pairs of preanal setae and a pair of elliptical pores. Primary metapodal platelets $25 \mu$ long, $4 \mu$ wide; accessory platelets $8 \mu$ by $2 \mu$. Genital plate $95 \mu$ wide. Metapodal setae, but not the plates, visible with ordinary-light microscope. Cervix and atrium of spermatheca, combined lengths, about $50 \mu$. Leg IV with macroseta on basitarsus $65 \mu$, on genu $50 \mu$.

Male. Chelicera peculiarly short and obconical, similar to that of the female but with a single large subapical tooth. Dorsal shield $245 \mu$ long, $180 \mu$ wide; ventri-anal plate with same pattern of preanal setae and pores as that of female.

\section{COLLECTION DATA}

Contra Costa County: 2.5 miles below south entrance to Mount Diablo State Park, May 27, 1959 (R. O. Schuster). Lake County: Clear Lake region, August 29, 1959 (L. M. Smith, R. O. Schuster). Marin County: Black Point, March 24, near Bolinas, and 6 miles east of Point Reyes Station, April 7, 1960 (R. O. Schuster). Mendocino County: Talmage, July 29, 1959 (L. M. Smith, R. O. Schuster). NAPA County: Napa, October 28, 1958 (J. J. Skelsey). Placer County: Foresthill, June 6, 1959 (F. C. Raney) ; Loomis, May 22, 1958 (S. F. Bailey); north of Roseville, July 23, 1959 (L. M. Smith,
R. O. Schuster). Sacramento County: Isleton, November 3, 1958 (R. O. Schuster). SAN Joaquin County: Lockeford, December 21, 1956 (L. M. Smith, R. O. Schuster) ; northeast of Lodi, May 22, 1959 (R. O. Schuster). SAN MATEO County: Redwood City, September 13, 1958 (R. O. Schuster). Yolo County: Davis, September 27, 1956, and August 20, 1957 (L. M. Smith), September 11, 1957, and October 17 and 23, 1958 (R. O. Schuster) ; 3 miles north of Rumsey, August 29, 1959 (L. M. Smith, R. O. Schuster); 5.4 miles southwest of Winters, May 29, 1959. (We have seen specimens from Villa San Miguel, north of Ensenada, Mexico.)

Found on Dicentra formosa, Platanus, Prunus domestica, Prunus sp., Quercus, Umbellularia, and Vitis-all on foliage. This mite has been seen feeding on Eotetranychus willamettei and on eriophyids, especially the peach silver mite.

\section{Amblyseius lecanis, new species} (Fig. 22)

The single pair of metapodal platelets distinguishes Amblyseius lecanis from the related species $A$. meridionalis (Berlese) and A. morgani (Chant). The presence of ventri-anal pores and the large size of the metapodal platelets distinguish it from $A$. longulus (Berlese).

Female. Chelicera $44 \mu$ long, with about four weak teeth on the fixed digit and none on the shorter, movable digit. Dorsal shield $470 \mu$ long, $386 \mu$ wide, dark brown, very convex. Vertical setae $24 \mu$; dorsocentrals (four pairs) and promediolaterals (one pair) appear to be represented by insertions only, although microsetae are distinguishable at magnifications of 1200-1500×; clunals $12 \mu$; prolaterals I $57 \mu$, II and III $8 \mu$, IV $100 \mu$; postlaterals I-IV $8 \mu, \mathrm{V} 118 \mu$; postmediolaterals $110 \mu$; sublaterals I $16 \mu$, II $10 \mu$; all setae simple. Peritreme extending to base of vertical seta. Ventri-anal plate $195 \mu$ wide, $161 \mu$ long, with three 
pairs of preanal setae and with a pair of pores behind and mediad to the caudad setae. Single pair of metapodal platelets, $167 \mu$ long, $27 \mu$ wide. Genital plate $134 \mu$ wide. Sternal plate much wider than long, with three pairs of setae. Metasternal platelets large. Cervix of spermatheca $21 \mu$ long, atrium $12 \mu$. Leg IV with macroseta on basitarsus $57 \mu$, on tibia $54 \mu$, on genu $57 \mu$.

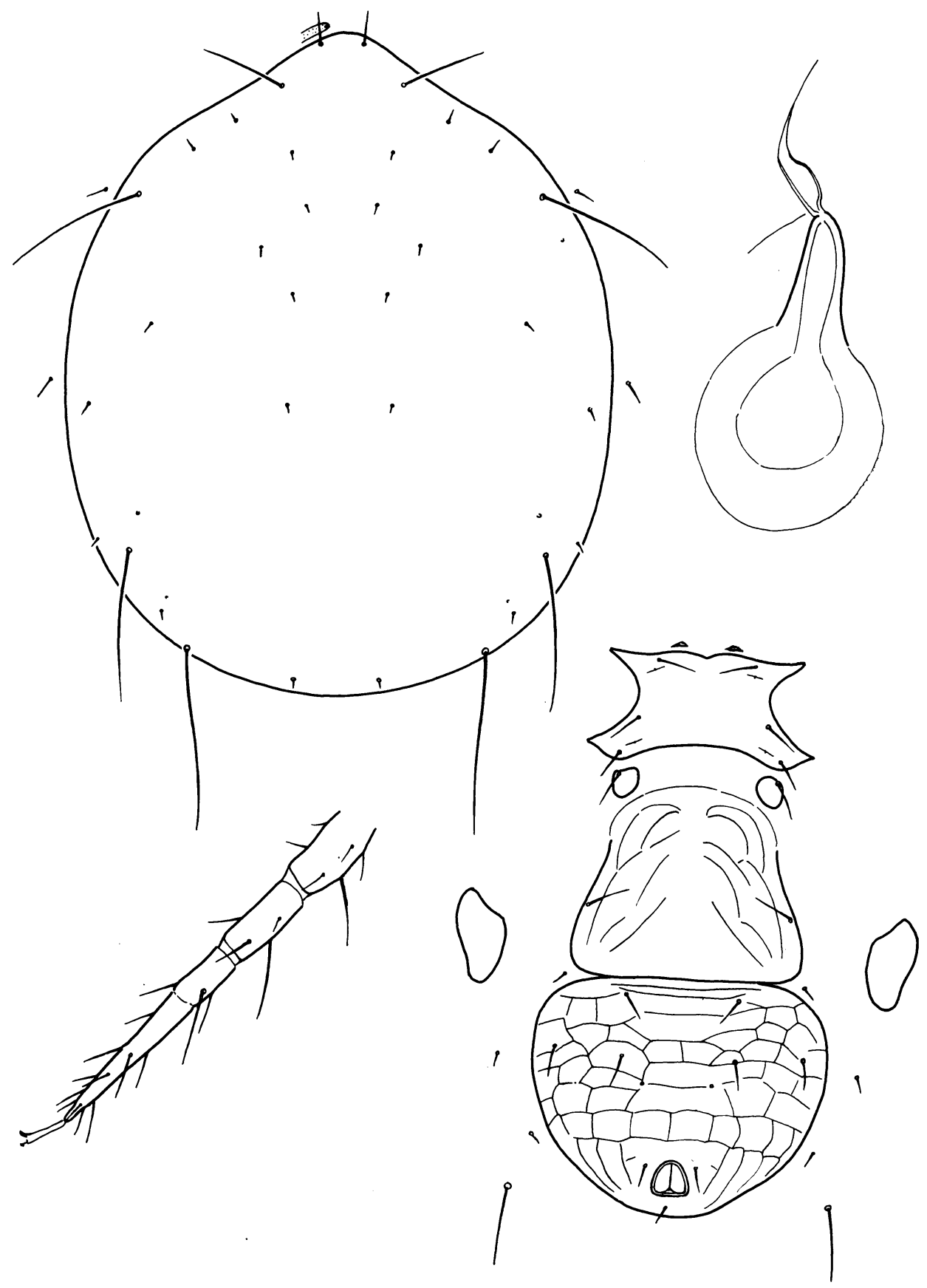

Fig. 22. Amblyseius lecanis, new species. 


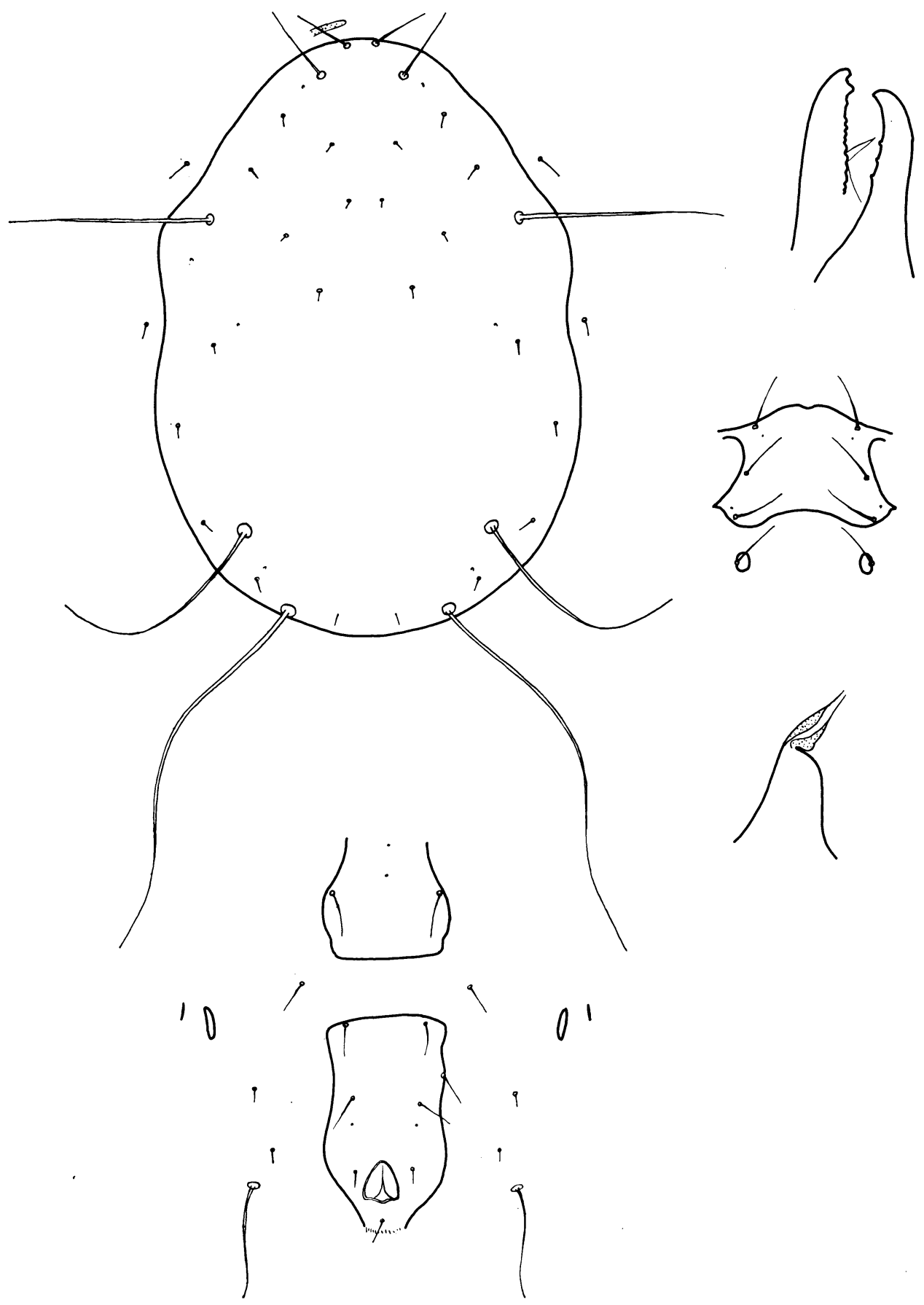

Fig. 23. Amblyseius elongatus (Garman). 
Male. Unknown.

Holotype. Female, north side of Montezuma Slough near Grizzly Island, Solano County, October 20, 1959 (R. O. Schuster); type no. 2782 in the U. S. National Museum.
Paratype. Female, data same as for holotype.

The specimens were collected from soil and from plants in a salt marsh with mixed vegetation of Distichlis spicata, Mesembryanthemum, and Salicornia ambigua.

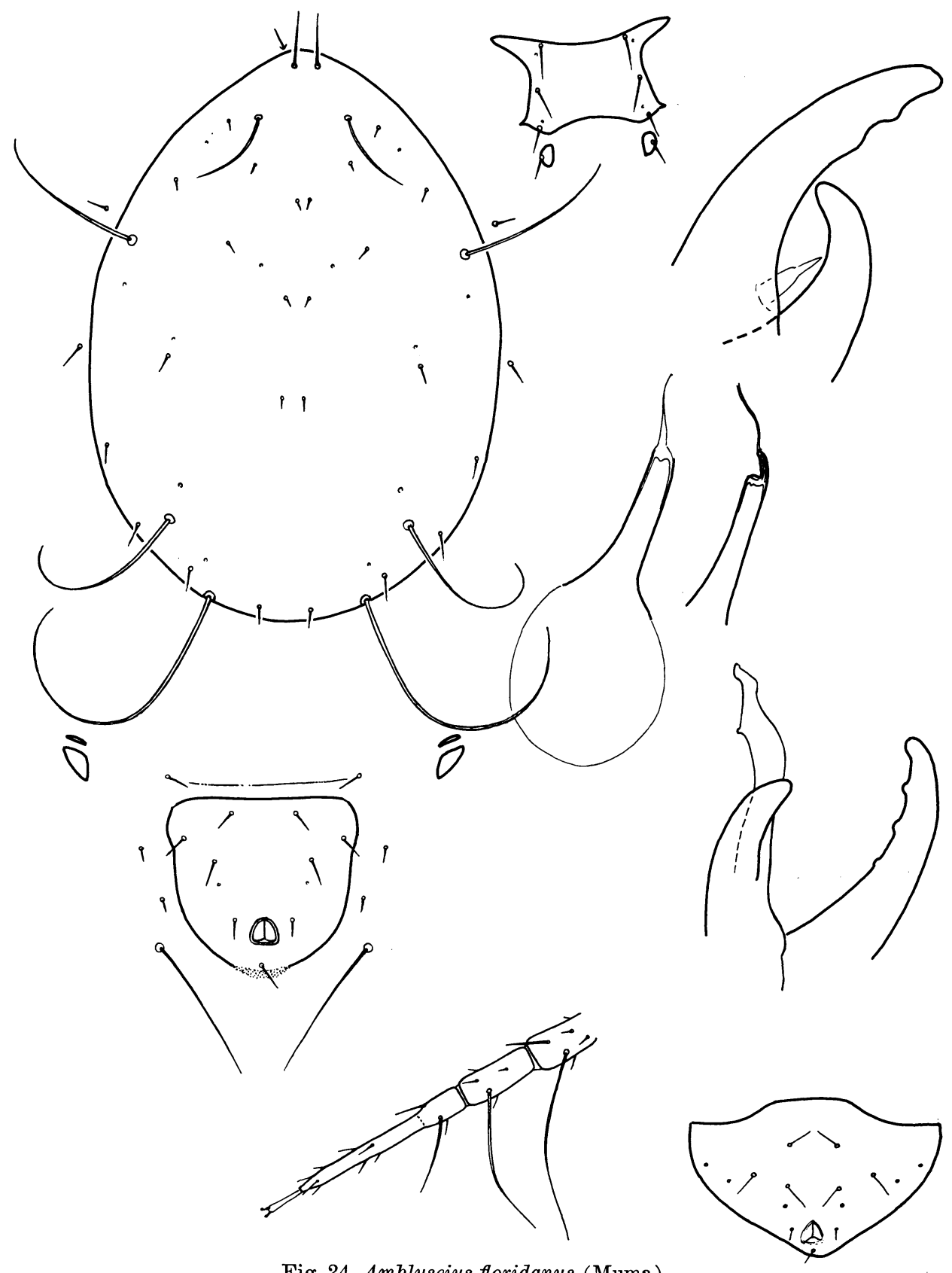

Fig. 24. Amblyseius floridanus (Muma). 


\section{Amblyseius elongatus (Garman)}

(Fig. 23)

Amblyseiopsis elongatus Garman, 1958, p. 79. Amblyseius elongatus (Garman). Kennett, 1958, p. 476.

Typhlodromus (Amblyseius) guatemalensis Chant, $1960 a$, p. 83.

This species is not obviously related to any other California species. It resembles $A$. terrestris (Chant) in setal pattern but has a shorter and thicker cervix of the spermatheca.

Female. Chelicera with one large subapical tooth and nine or more smaller teeth on the fixed digit, the movable digit with three small teeth. Dorsal shield $370 \mu$ long, $260 \mu$ wide, with three pairs of dorsocentral setae. Vertical setae $35 \mu$; dorsocentrals about $5 \mu$; clunals $8 \mu$; prolaterals I $44 \mu$, II and III $8 \mu$, IV $128 \mu$; postlaterals I-IV about $14 \mu, \mathrm{V}$ $270 \mu$; promediolaterals $5 \mu$, postmediolaterals $135 \mu$; sublaterals I $23 \mu$, II $12 \mu$. Peritreme extending forward to base of vertical seta. Ventri-anal plate $80 \mu$ wide, $135 \mu$ long, usually with three pairs of preanal setae and with a pair of pores directly behind the third pair of setae. Primary metapodal platelets $25 \mu$ long, $5 \mu$ wide; accessory platelets $16 \mu$ by $3 \mu$. Genital plate $77 \mu$ wide. Metasternal platelets distinct. Cervix of spermatheca $20 \mu$ long, atrium $5 \mu$. Leg IV with macroseta on basitarsus $95 \mu$, on tibia $90 \mu$, on genu $125 \mu$.

Male. Unknown.

\section{COLLECTION DATA}

Alameda County: Albany, July 13, 1955 (C. E. Kennett). (Original specimens on orchids from Guatemala.)

Found in greenhouse, on strawberry plants.

\section{Amblyseius floridanus (Muma)}

(Fig. 24)

Amblyseiopsis floridanus Muma, 1955, p. 264. Typhlodromus (Amblyseius) floridanus (Muma). Chant, $1960 a$, p. 85.

Amblyseius floridanus (Muma). Muma, 1961, p. 287.

The exceptionally large chelicerae are unique and allow easy recognition of this species. California specimens normally have two subapical teeth on the fixed digit, but some have three, as does the typical form from Florida.

Female. Fixed digit of chelicera $50 \mu$ long, with two obsolete to welldeveloped subapical teeth, pilus dentilis occurring basally; movable digit also about $50 \mu$, but its apex meeting the fixed digit near the middle. Dorsal shield $355 \mu$ long, $220 \mu$ wide, with four pairs of dorsocentral setae. Verticals $34 \mu$; dorsocentrals I-III $6 \mu$, IV $8 \mu$; clunals $10 \mu$; prolaterals I $63 \mu$, II and III $6 \mu$, IV $120 \mu$; postlaterals I $14 \mu$, II $19 \mu$, III and IV $23 \mu, \mathrm{V} 215 \mu$; promediolaterals $5 \mu$, postmediolaterals $150 \mu$; sublaterals I $16 \mu$, II $13 \mu$; all setae simple. Peritreme extending past base of prolateral I. Ventri-anal plate $105 \mu$ wide, $115 \mu$ long, with three pairs of preanal setae and with a pair of pores behind the caudad pair of setae. Primary metapodal platelets $25 \mu$ long, $8 \mu$ wide; accessory platelets $16 \mu$ by $3 \mu$. Three pairs of ventrolateral setae. Genital plate $80 \mu$ wide. Sternal plate with three pairs of setae. Cervix of spermatheca $24 \mu$ long, atrium poorly defined. Leg IV with macroseta on basitarsus $70 \mu$ long, on tibia $100 \mu$, on genu $115 \mu$; macrosetae on other genuaon that of leg III $50 \mu$; leg I with macroseta on tarsus also, $60 \mu$.

Male. Dorsal shield $270 \mu$ long, $195 \mu$ wide. Ventri-anal plate with three pairs of preanal setae and a pair of preanal pores; two additional pairs of pores at lateral margins of plate.

\section{COLLECTION DATA}

Alpine County: 3 miles south of Markleeville, May 11, 1959 (L. M. Smith); Woods Lake area, July 17, 1960 (C. Moore). Amador County: Fiddletown, March 21, 1959 (L. M. Smith). El Dorado County: 2.6 miles east of Pacific House, August 22, 1958 (G. A. Marsh). Fresno County: Dinkey Creek, July 1, 1956 (E. L. Meyer). Inyo County: 3 miles north of Independence, May 12, 1959 (L. M. Smith). 
LAKe County: Lake Pillsbury area, September 1957 (D. W. Price); 15 miles north of Upper Lake, July 27, 1958 (A. A. Grigarick). LASSEN County: Bieber, April 17, 1958 (R. W. Gerhardt) ; near McCoy Flat Reservoir, September 28, 1958 (J. Campbell). Marin County: Bolinas, March 24, and 1 mile west of Inverness, March 1, 1960 (R. O. Schuster) ; 2 miles west of Inverness, September 14, 1960 (W. G. Iltis). Mariposa County: Yosemite Valley, January 19, 1958 (D. W. Price). Mendocino County: 24 miles east of Covelo, July 26, 1960, and 11 miles south of Eel River Ranger Station, July 18, 1959 (A. A. Grigarick); 3 miles north of Potter Valley, July 29, 1959 (L. M. Smith, R. O. Schuster). Mono County: 11 miles south of Bridgeport, May 11, 1959 (L. M. Smith). Monterey County: Pebble Beach, September 19, 1959 (L. M. Smith). Napa County: 10 miles south of Monticello, March 17, 1957 (R. O. Schuster); Napa, January 14, 1959 (J. J. Skelsey) ; 3 miles north of Saint Helena, December 15, 1958 (F. C. Raney). Nevada County: Soda Springs Resort, May 19, 1959 (F. C. Raney); 14 miles north of Truckee, September 9, 1958 (A. A. Grigarick). Plumas County: 8 miles northwest of Chester, August 10, 1959 (E. Lindquist); Johnsville, June 28 and October 25, 1959 (J. S. Buckett). Sacramento County: near Folsom, April 2, 1960 (R. F. Wilkey). SAN Diego County: 7 miles east of Jamul, May 10, 1958 (F. C. Raney) ; 10 miles south of Julian, March 26, 1959 (L. M. Smith). SaN Mateo County: Cahill Ridge, March 10, 1958, and June 11, 1960; Pigeon Point, July 12, 1958; 1 mile south of Pilarcitos Lake, November 12, 1956; Sawyer Ridge, November 18, 1956; Sweeney Ridge, July 4 and October 2, 1960 (all collected by D. W. Price). Shasta County: Ingot, February 3, 1959 (R. W. Gerhardt). SierrA County: Bassett's Lodge, July 30, 1958 (A. A. Grigarick) ; Yuba Pass Campground, at 6,700 feet, June 20, 1960
(F. C. Raney). Siskiyou County: Dunsmuir, July 18, 1959 (F. C. Raney). Solano County: 14 miles north of Vacaville, December 1, 1956 (R. O. Schuster). Sonoma County: 2 miles west of Petrified Forest, October 25, 1959 (J. S. Buckett); 7 miles east of Sonoma, August 29, 1959 (A. Bray). Stanislaus County: LaGrange, March 7, 1960 (R. P. Allen). Tehama County: 5 miles south of Mineral, June 28, 1958 (F. C. Raney). Tulare County: 1 mile east of Lemoncove, June 13, and 2 miles west of Springville, May 13, 1959 (L. M. Smith). Yolo County: Casey Flat, June 9, 1960 (W. W. Wiard) ; 4 miles north of Rumsey, June 3, 1960 (R. O. Schuster) ; 5.4 miles south of Winters, May 29, 1959 (F. C. Raney, L. M. Smith, R. O. Schuster). (Originally described from Florida; collected in the west in Arizona, New Mexico, Oregon, and Washington.)

Found in litter of the following: Abies concolor, A. nobilis, Acer glabrum douglasi, Alnus sp., Amorpha californica, Cupressus, Lythrum adsurgens, Pinus contorta, P. muricata, $P$. ponderosa, Populus fremontii, Prunus, Pseudotsuga taxifolia, Quercus lobata, Salix, and Umbellularia californica; of chaparral, and of a rhizomatous grass; and in compost of manure and Umbellularia leaves. The prey of this common mite is unknown.

\section{Amblyseius schusteri (Chant)} (Fig. 25)

Typhlodromus (Amblyseius) schusteri Chant, $1960 a$, p. 88.

Amblyseius schusteri (Chant). Muma, 1961, p. 287.

This species is closely related to $\mathrm{Am}$ blyseius aerialis (Muma), from which it differs in having a proportionately wider ventri-anal plate. The illustration accompanying the original description of $A$. schusteri indicates noncircular pores in the ventri-anal plate, but our specimens with circular pores are probably conspecific. In some specimens, one or both of the ventri-anal pores are directly behind the caudad 


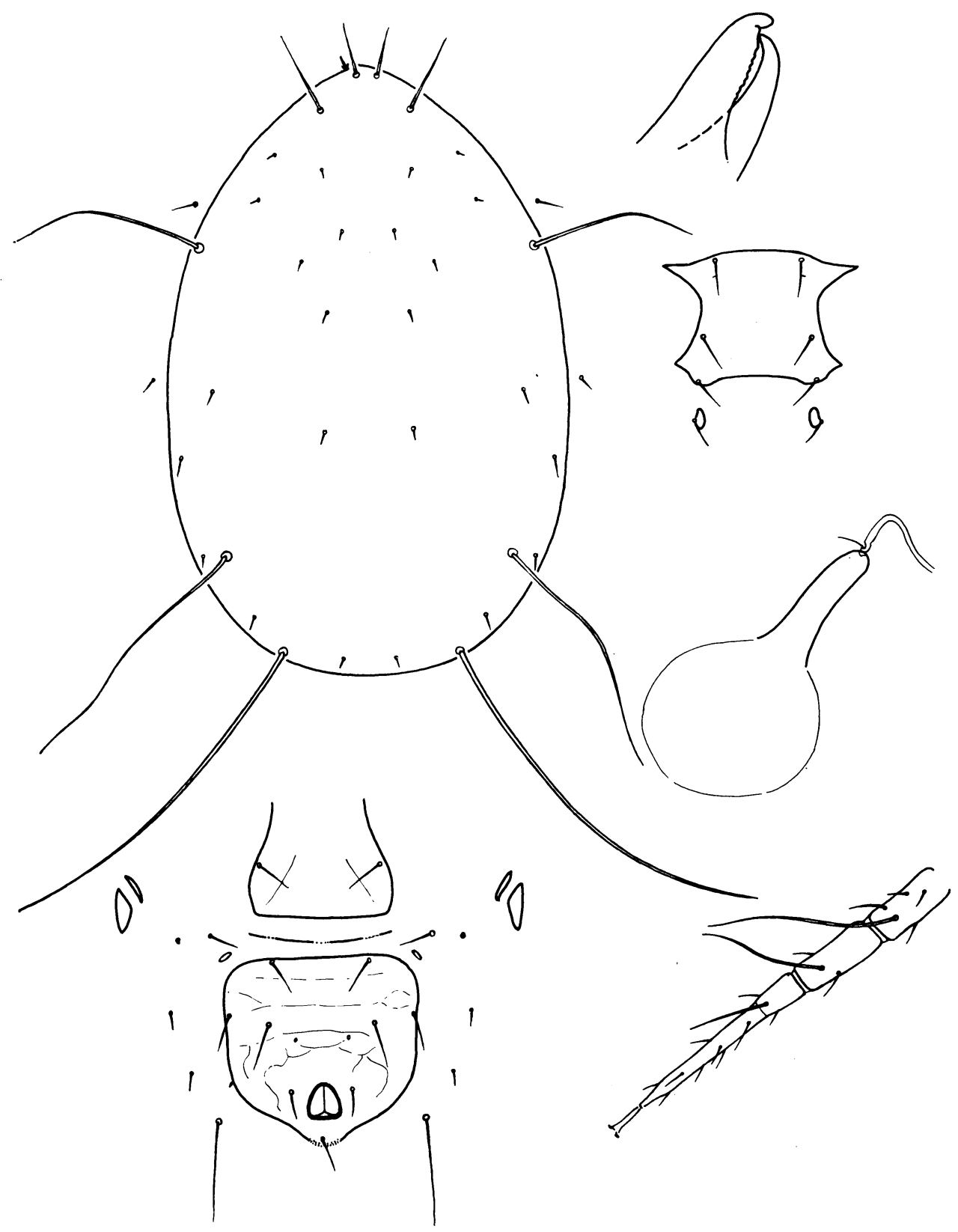

Fig. 25. Amblyseius schusteri (Chant).

pair of preanal setae. In $A$. aerialis the spermatheca is thinner than that of $A$. schusteri, and the atrium appears as a blunt knob at its apex.

Female. Chelicera with about eight teeth on fixed digit. Dorsal shield $385 \mu$ long, $280 \mu$ wide, with four pairs of dorsocentral setae. Verticals $34 \mu$, dorsocentrals $6 \mu$ to $8 \mu$, clunals $12 \mu$; prolaterals I $42 \mu$, II and III $10 \mu$, IV $140 \mu$; postlaterals I $10 \mu$, II $15 \mu$, III and IV $12 \mu, \mathrm{V} 320 \mu$; promediolaterals $8 \mu$, postmediolaterals $200 \mu$; sublaterals I $16 \mu$, II $8 \mu$; all setae essentially smooth. Peri- 
treme extending forward to base of vertical seta. Ventri-anal plate $130 \mu$ wide, $130 \mu$ long, with three pairs of preanal setae and with a pair of pores behind and mediad to the caudad setae. Primary metapodal platelets $25 \mu$ long, $8 \mu$ wide; accessory platelets $22 \mu$ by $4 \mu$. Genital plate $90 \mu$ wide. Metasternal platelets of irregular shape but distinct. Cervix of spermatheca $25 \mu$ long, atrium very small, scarcely differentiated from major duct. Leg IV with macroseta of basitarsus $67 \mu$, of tibia $115 \mu$, of genu $150 \mu$; macrosetae on genua of legs III to I decreasing in size from $67 \mu$ to $50 \mu$.

Male. Dorsal shield $300 \mu$ long, $200 \mu$ wide. Three pairs of preanal setae on ventri-anal plate; pores variable in location.

\section{COLLECTION DATA}

Fresno County: Kaiser Pass, August 6, 1956 (R. O. Schuster). Santa Cruz County: January 21, 1954 (C. E. Kennett). Sonoma County: 2 miles west of Petrified Forest, October 25, 1959 (J. S. Buckett). Tuolumne County: South Grove, Calaveras Big Trees State Park, June 16, 1959 (R. O. Schuster, L. M. Smith).

Found in litter.

\section{Amblyseius largoensis (Muma)}

(Fig. 26)

Amblyseiopsis largoensis Muma, 1955, p. 266. Typhlodromus (Amblyseius) largoensis (Muma). Chant, $1960 a$, p. 96.

Amblyseius (Amblyseiulus) largoensis (Muma). Muma, 1961, p. 287.

This species is similar to Amblyseius schusteri and to $A$. aerialis. It is distinguished from the former particularly by the dissimilarity of the spermathecae and from the latter only by the placement of the preanal pores.

Female. Chelicera with 11 teeth in addition to the pilus dentilis on the fixed digit and three or four small, recurved teeth on the movable digit. Dorsal shield $383 \mu$ long, $260 \mu$ wide, with four pairs of dorsocentral setae. Verticals $39 \mu$; dorsocentrals I and II $8 \mu$, III and IV $10 \mu$; clunals $8 \mu$; prolaterals I $45 \mu$, II and III $17 \mu$, IV $115 \mu$; postlaterals I $13 \mu$, II $16 \mu$, III $17 \mu$, IV $13 \mu$, V $270 \mu$; sublaterals I $12 \mu$, II $10 \mu$; all setae simple. Peritreme extending past base of prolateral I. Ventri-anal plate $76 \mu$ wide at the level of the para-anal setae, narrowed anteriorly, with three pairs of preanal setae and a pair of crescentic pores. Primary metapodal platelets $24 \mu$ long, $6 \mu$ wide; accessory platelets $17 \mu$ by $3 \mu$. Genital plate $76 \mu$ wide. Metasternal platelets small but distinct. Cervix of spermatheca $23 \mu$ long, thin; atrium appearing as a distal knob. Leg IV with macroseta on basitarsus $85 \mu$, on tibia $77 \mu$, on genu $105 \mu$; macroseta on genu of leg III $45 \mu$, of leg II $39 \mu$, of leg I $44 \mu$, and on tarsus of leg I $55 \mu$.

Male. Unknown.

\section{COLLECTION DATA}

Alameda County: Berkeley Campus, June 18, 1958 (C. D. Brickhill). Marin County: near Bolinas, March 24 and April 7, 1960 (R. O. Schuster); 1 mile west of Inverness, March 1, 1960 (A. A. Grigarick, R. O. Schuster, L. M. Smith). (Recorded from Florida, Guatemala, and Mexico.)

Found in litter of Pinus muricata and on foliage of Pittosporum and of Umbellularia californica.

\section{Amblyseius palustris (Chant), new combination}

(Fig. 27)

Typhlodromus (Amblyseius) palustris Chant, $1960 b$, p. 136.

The five pairs of short dorsocentral setae and the wide ventri-anal plate allow easy recognition of this species.

Female. Chelicera about $35 \mu$ long, with few teeth on fixed digit. Dorsal shield $460 \mu$ long, $370 \mu$ wide, with five pairs of dorsocentral setae. Verticals $18 \mu$; dorsocentrals $8 \mu$; clunals $11 \mu$; prolaterals I $30 \mu$, II $21 \mu$, III $34 \mu$, IV $46 \mu$; postlaterals I $13 \mu$, II and III $34 \mu$, IV $41 \mu$, $\mathrm{V} 54 \mu$; promediolaterals $8 \mu$, postmediolaterals $46 \mu$; sublaterals I and II $17 \mu$; all setae simple. Peritreme extending to 


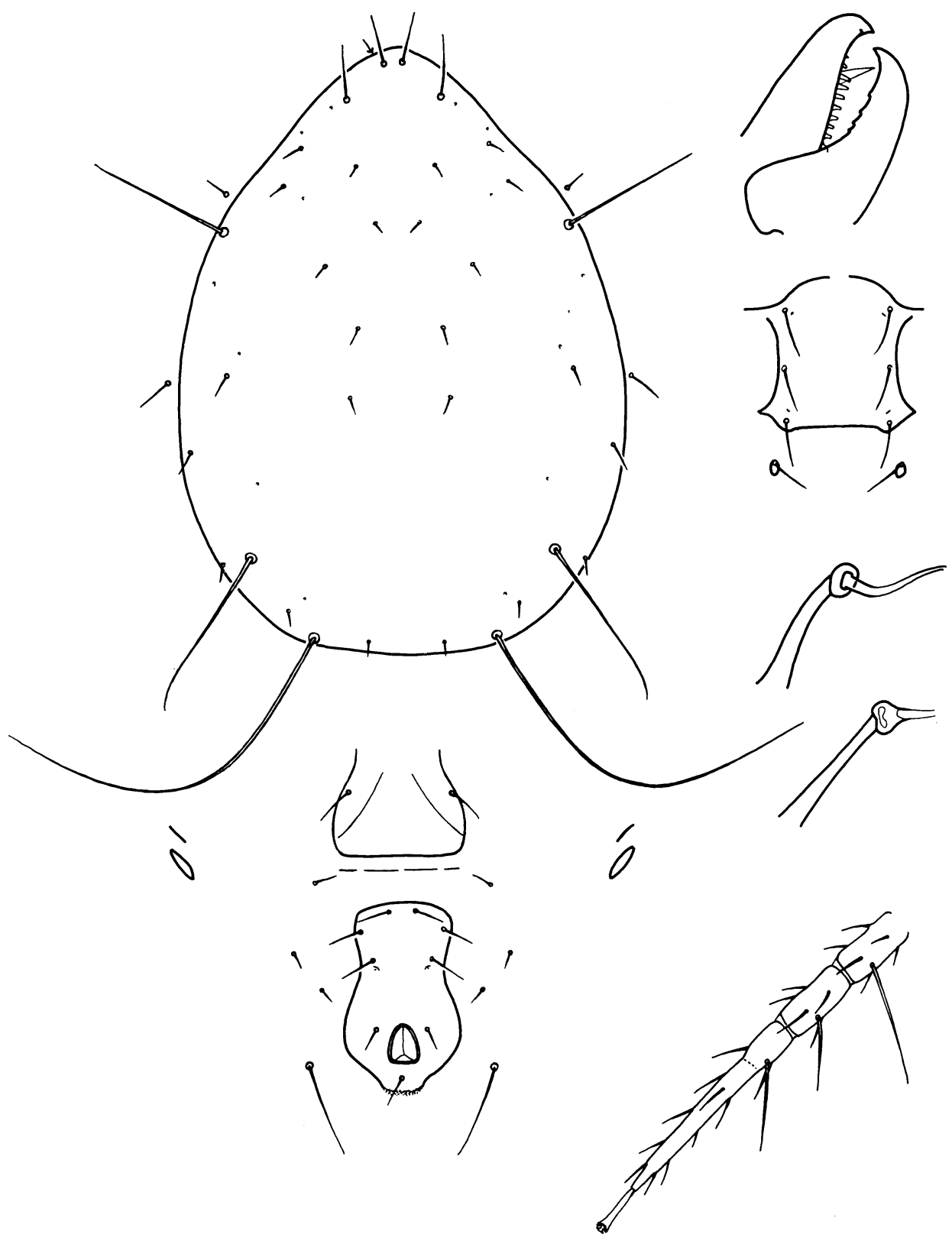

Fig. 26. Amblyseius largoensis (Muma).

base of vertical seta. Ventri-anal plate $185 \mu$ wide and about four fifths as long, with three pairs of preanal setae and with a pair of pores mediad and posterior to the caudad setae. Primary metapodal platelets $35 \mu$ long, $11 \mu$ wide; accessory platelets circular, about $5 \mu$ wide. Genital plate $130 \mu$ wide. Two small platelets anterior to sternal plate; metasternal platelets large. Cervix and atrium of spermatheca, combined lengths, $25 \mu$. Leg IV with macroseta on basitarsus $50 \mu$.

Male. Ventri-anal plate with three 
pairs of preanal setae and a pair of preanal pores; two additional pairs of pores at lateral margins of plate.

\section{COLLECTION DATA}

Marin County: 1 mile west of Bolinas, January 9, 1960 (C. L. Judson).
Napa County: Napa, February 3 and 24, 1959 (R. O. Schuster). Plumas County: 8 miles northwest of Chester, August 10, 1959 (E. E. Lindquist). Sacramento County: Carmichael, February 19, 1959 (R. F. Wilkey). Solano County: October 20, 1959 (R.
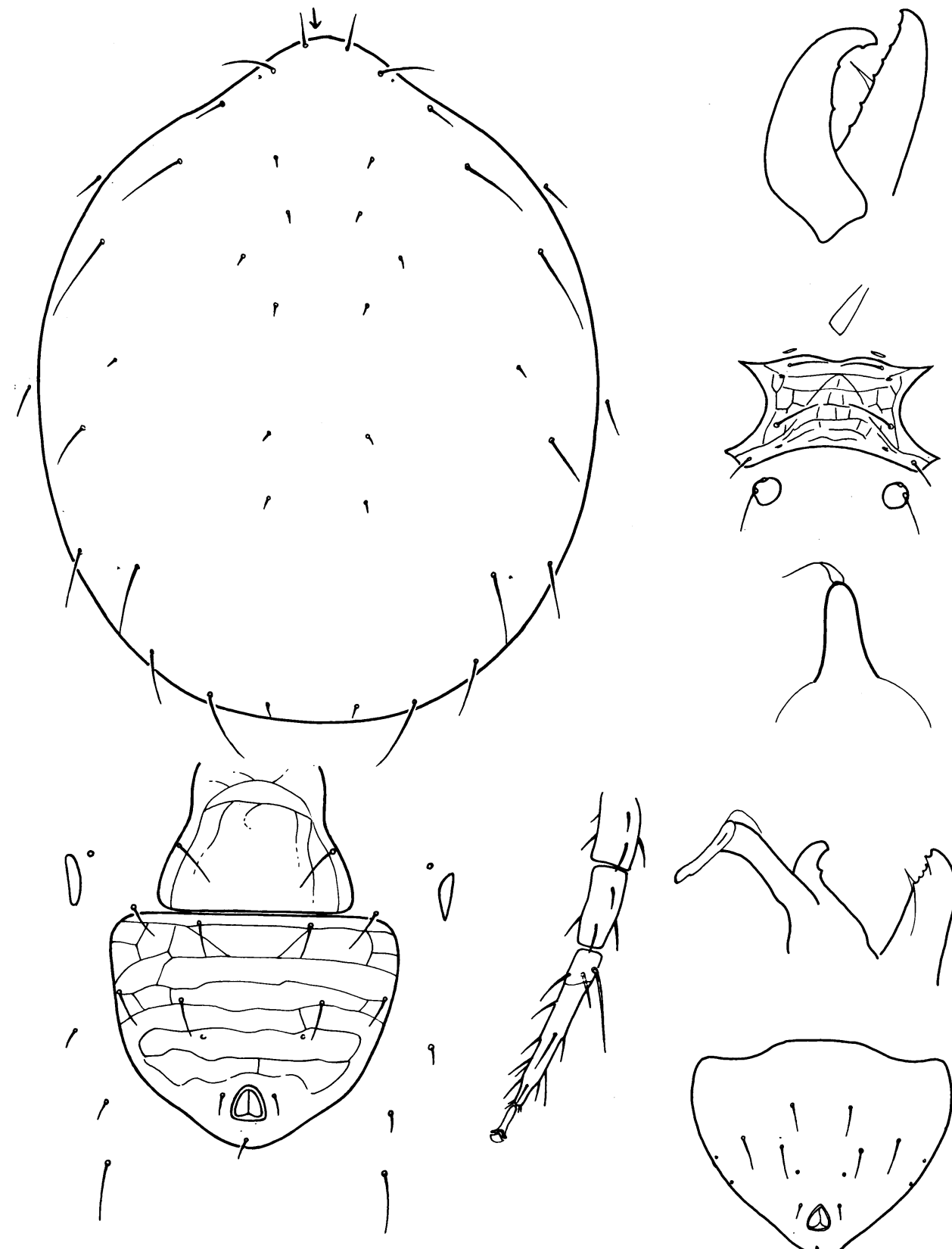

Fig. 27. Amblyseius palustris (Chant).

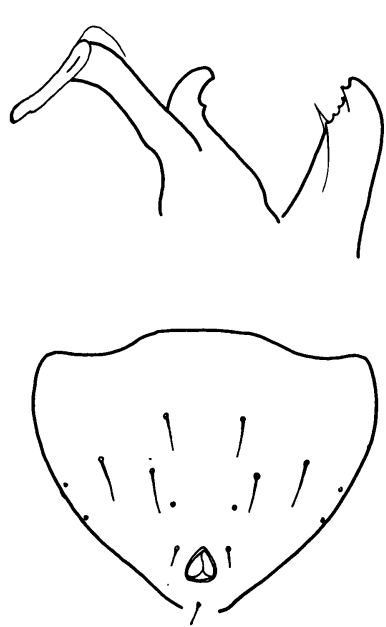


O. Schuster). Yolo County: Casey Flat, June 9, 1960 (W. Wiard).

Found on foliage of Prunus domestica and in soil or litter as follows: Malus; Plantago lanceolata and Poa, mixed; Prunus domestica, Pyracantha, and mixed Distichlis spicata, Mesembryanthemum, and Salicornia ambigua; irrigated pasture, moss. Prey unknown.

\section{Amblyseius similoides Buchelos and Pritchard (Fig. 28)}

Amblyseius similoides Buchelos and Pritchard, 1960, p. 179.

Amblyseius similoides from California resembles $A$. similis Koch from Europe. However, $A$. similis has a short, cup-shaped spermatheca, whereas the spermatheca of $A$. similoides has a tapering cervix and a large and conspicuous atrium.

Female. Chelicera $40 \mu$ long, with 10 to 12 teeth on fixed digit, three on movable digit. Dorsal shield $420 \mu$ long, $250 \mu$ wide, with four pairs of dorsocentral setae. Vertical setae $38 \mu$; dorsocentrals $6-8 \mu$; clunals $10 \mu$; prolaterals I $57 \mu$, II $25 \mu$, III $49 \mu$, IV $68 \mu$; postlaterals I $10 \mu$, II $23 \mu$, III $16 \mu$, IV $13 \mu$, $\mathrm{V} 110 \mu$; promediolaterals $6-8 \mu$, postmediolaterals $70 \mu$; sublaterals I $30 \mu$, II $18 \mu$; all setae simple. Peritreme extending forward to base of vertical seta. Ventri-anal plate $90 \mu$ wide, $140 \mu$ long, with three pairs of preanal setae and with a pair of crescentic pores between the third setae. Primary metapodal platelets $28 \mu$ long, $5 \mu$ wide; accessory platelets $16 \mu$ by $2 \mu$. Genital plate $90 \mu$ wide. Metasternal platelets distinct. Cervix and atrium of spermatheca, combined lengths, $25 \mu$. Leg IV with macroseta on basitarsus $80 \mu$, on tibia $50 \mu$, on genu $65 \mu$.

Male. Dorsal shield $300 \mu$ long, $200 \mu$ wide. Ventri-anal plate with three pairs of preanal setae and with a pair of crescentic pores, between and slightly behind the third setae.

\section{COLLECTION DATA}

Alameda Countr: Berkeley, May 27 and June 30, 1959 (B. E. Pullen); Oakland, September 8, 1957 (R. O. Schuster). Marin County: June 25, 1958 (C. D. Brickhill). Napa County: Napa, many dates, 1958 and 1959 (S. F. Bailey, J. J. Skelsey, R. O. Schuster). Sacramento County: Florin, February 20, 1952 (W. W. Allen). SAN Diego County: Encinitas, August 18, 1953 (J. Hall); San Diego, June 27, 1958 (L. M. Smith). San Mateo County: Redwood City, November 22, 1956, September 2, 1957, October 26, 1958, and September 13, 1959 (R. O. Schuster). Santa Clara County: Berryessa, February 6, 1953 (W. W. Allen); Cupertino, January 23, 1940 (L. M. Smith); San Jose, July 18, 1958 (A. E. Michelbacher) and July 25, 1958 (E. Gould); Santa Clara, July 1, 1958. Sonoma County: 1 mile south of Trenton, September 3, 1957 (R. O. Schuster, L. M. Smith).

Found on Fragaria, Juglans, Persea, Peumus boldus, Prunus domestica, Quercus agrifolia, Vitis, and ivy: all on foliage. Prey includes Eupalopsis mali, Steneotarsonemus pallidus, and Tetranychus pacificus.

\section{Amblyseius chorites, new species}

(Fig. 29)

This species is closely related to $\mathrm{Am}$ blyseius andersoni (Chant) but differs in the following respects: In $A$. chorites the macroseta of basitarsus IV is not longer than that of genu IV, the postmediolateral setae are nearly as long as postlaterals $\mathrm{V}$, the preanal pores are reduced or lacking, and the placement of ventrolateral and preanal setae is erratic. In some specimens, as in the male of figure 29, the second and third pairs of preanal setae are arranged in a transverse row.

Female. Dorsal shield $385 \mu$ long, $235 \mu$ wide, with four pairs of dorsocentral setae. Vertical setae $34 \mu$; dorsocentrals and clunals about $8 \mu$; pro- 

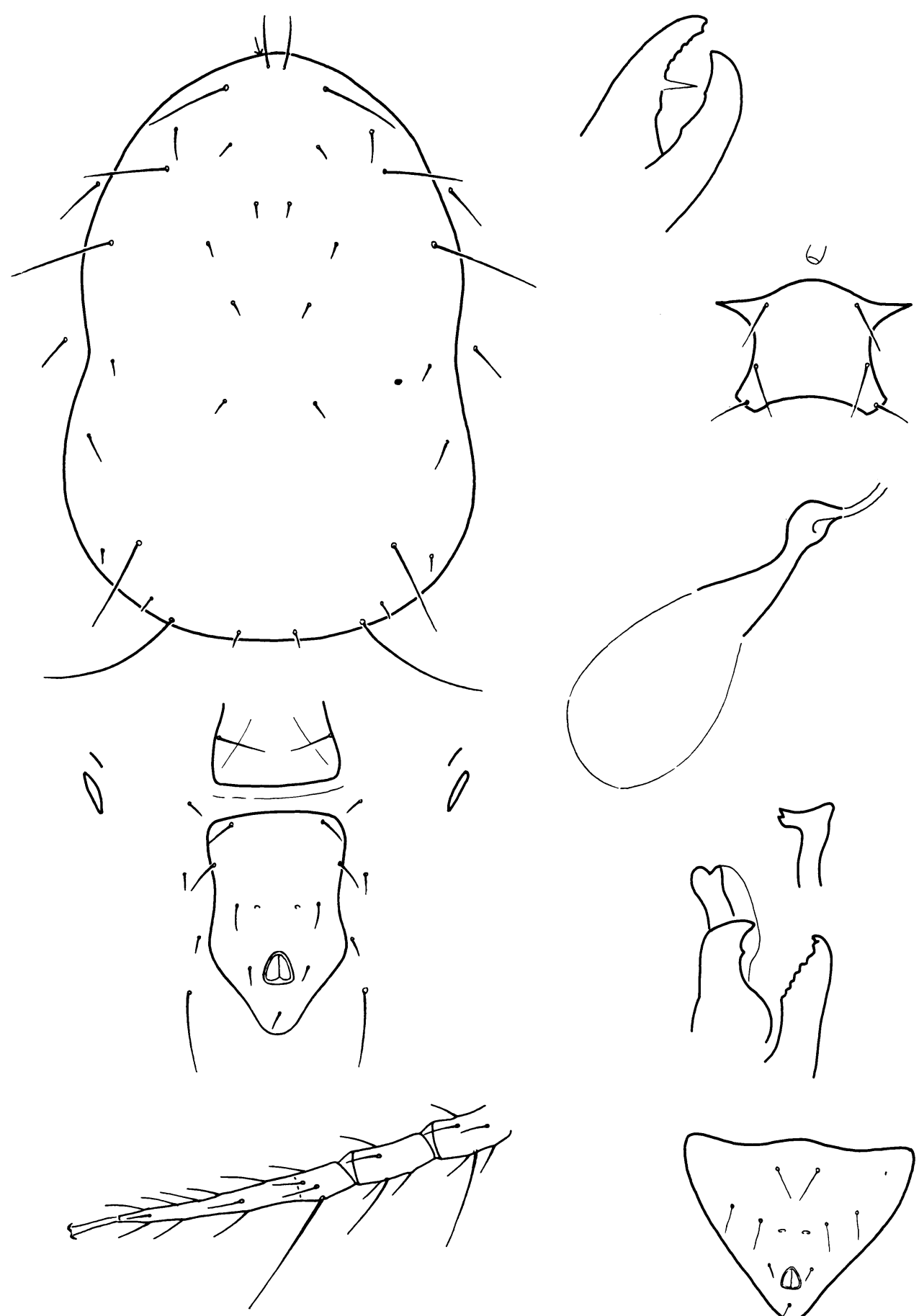

Fig. 28. Amblyseius similoides Buchelos and Pritchard. 


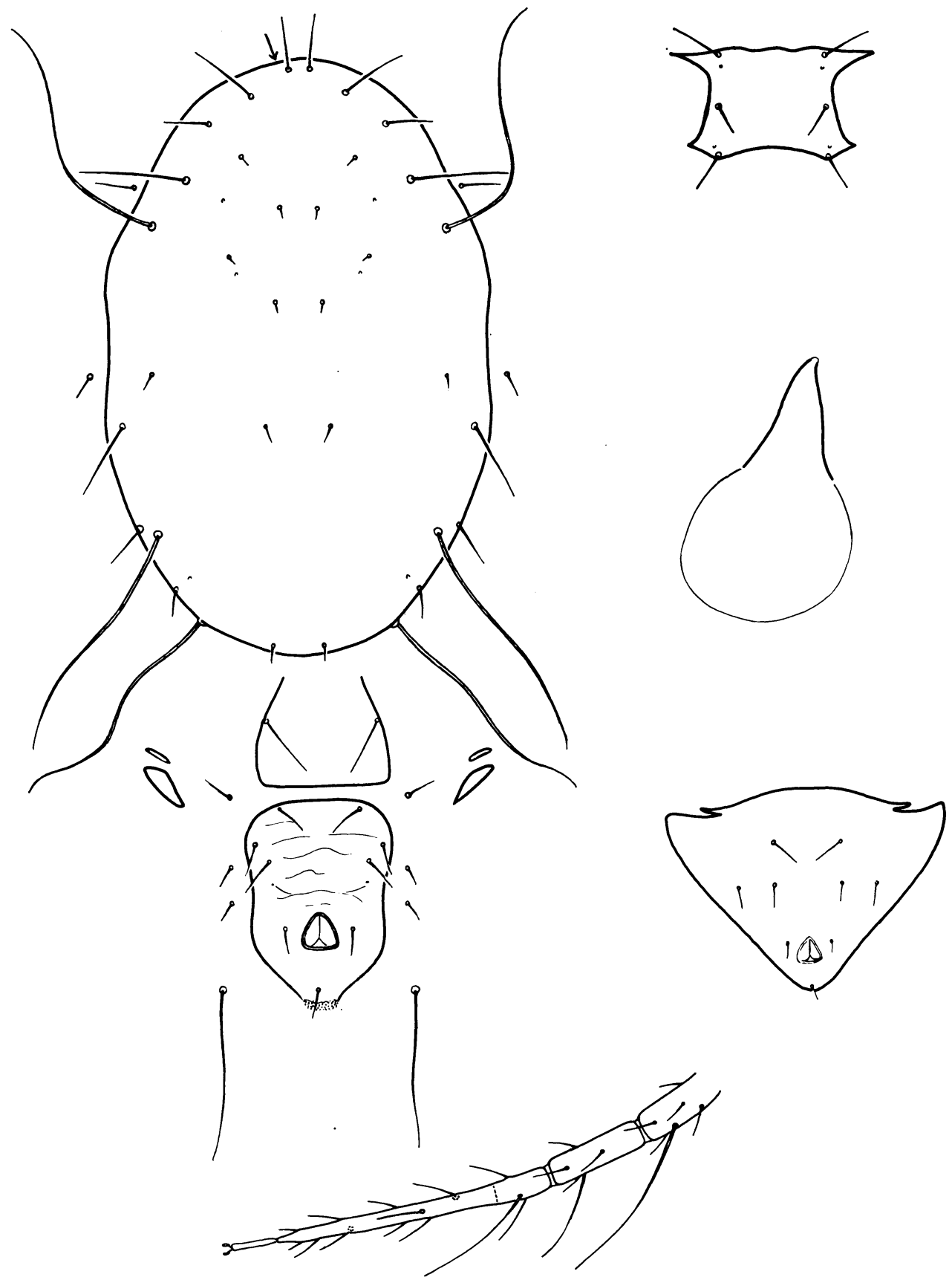

Fig. 29. Amblyseius chorites, new species.

laterals I $60 \mu$, II $36 \mu$, III $70 \mu$, IV $125 \mu$; postlaterals I $14 \mu$, II $50 \mu$, III $27 \mu$, IV $23 \mu, \mathrm{V} 170 \mu$; promediolaterals $8 \mu$, postmediolaterals $135 \mu$; sublaterals I and II $16 \mu$; all setae simple. Peritreme ex- tending to vertical seta. Ventri-anal plate $95 \mu$ wide, $110 \mu$ long, with three pairs of preanal setae and usually with a pair of very small pores directly caudad to the third pair of setae. 
Primary metapodal platelets $31 \mu$ long, $6 \mu$ wide; accessory platelets $16 \mu$ by $3 \mu$. Genital plate $90 \mu$ wide. Metasternal platelets large. Combined lengths of cervix and atrium of spermatheca $21 \mu$. Leg IV with macroseta on basitarsus $90 \mu$, on tibia $65 \mu$, on genu $115 \mu$; leg III genu with macroseta $54 \mu$.

Male. Ventri-anal plate with three pairs of preanal setae, the pores small or lacking.

Holotype. Female, Rumsey, Youo County, July 29, 1959 (L. M. Smith, R. O. Schuster), in litter; type no. 2783 in the U. S. National Museum.

Paratypes. Eight females from the six collections listed below.

Marin County: Black Point, March 24, 1960 (R. O. Schuster). Plumas County: near Johnsville, October 25, 1959 (J. S. Buckett). SAN JoAQUIN County: Lockeford, November 16, 1956 (L. M. Smith, R. O. Schuster). Solano County: Five miles southeast of Dixon, September 3, 1959 (A. D. Bray). Yolo County: Three miles north of Rumsey, July 29 and August 29, 1959 (L. M. Smith, R. O. Schuster).

This species seems to prefer soil or litter habitats and has been taken from litter under a $\log$ of Abies concolor, from grape bark, and from soil along pasture fence rows.

\section{Amblyseius ablusus, new species} (Fig. 30)

This species is not obviously related to any described species of Amblyseius. It has prolateral setae II shorter than III and dorsocentral setae I and II considerably shorter than III and IV.

Female. Chelicera with three subapical teeth on fixed digit, one on movable digit. Dorsal shield $395 \mu$ long, $255 \mu$ wide, with four pairs of dorsocentral setae. Vertical setae $30 \mu$; dorsocentrals I and II $8 \mu$, III and IV $17 \mu$; clunals $10 \mu$; prolaterals I $46 \mu$, II $33 \mu$, III $46 \mu$, IV $70 \mu$; postlaterals I $17 \mu$, II $60 \mu$, III $30 \mu$, IV $28 \mu$, V $93 \mu$; promediolaterals $10 \mu$, postmediolaterals $84 \mu$; sublaterals I $23 \mu$, II $30 \mu$; postmedio- laterals and postlaterals $\mathrm{V}$ weakly serrate. Peritreme extending forward to base of vertical seta. Ventri-anal plate $100 \mu$ wide, $104 \mu$ long, with three pairs of preanal setae and with a pair of pores behind and mediad to the third setae. Primary metapodal platelets $31 \mu$ long, $6 \mu$ wide; accessory platelets $17 \mu$ by $2 \mu$. Genital plate $88 \mu$ wide. Metasternal platelets large. Cervix of spermatheca $30 \mu$ long, basal half tapering, distal half cylindrical; atrium $5 \mu$ long, crescent-shaped. Leg IV with macroseta on basitarsus $64 \mu$, on tibia $46 \mu$, on genu $61 \mu$.

Male. Dorsal shield $315 \mu$ long, $190 \mu$ wide. Ventri-anal plate with four pairs of preanal setae and a pair of pores.

Holotype. Female, 3 miles south of Markleeville, Alpine County, May 2, 1959 (L. M. Smith); type no. 2784 in the U. S. National Museum.

Specimens have been examined from Durango, Colorado (August 28, 1958, D. W. Price) and from Gardnerville, Nevada (May 10, 1959, L. M. Smith), from litter.

\section{Amblyseius asetus (Chant), new combination}

(Fig. 31)

Typhlodromus (Amblyseius) asetus Chant, $1960 a$, p. 80.

Amblyseius asetus differs from species with similar prolateral, anterior postlateral, and dorsocentral setae in that the cervix of the spermatheca is very short and broad.

Female. Chelicera with three to five subapical teeth on fixed digit, movable digit smooth. Dorsal shield $340 \mu$ long, $215 \mu$ wide, with three pairs of dorsocentral setae. Vertical setae $23 \mu$; dorsocentrals $6-8 \mu$; clunals $8 \mu$; prolaterals I $34 \mu$, II $17 \mu$, III $13 \mu$, IV $56 \mu$; postlaterals I $10 \mu$, II $8 \mu$, III and IV $10 \mu, \mathrm{V} 72 \mu$; promediolaterals $6 \mu$, postmediolaterals $72 \mu$; sublaterals I $16 \mu$, II $11 \mu$; postlaterals $\mathrm{V}$ faintly serrate; sublaterals I in some specimens occurring on the dorsal shield. Peritreme extending forward to base of vertical 


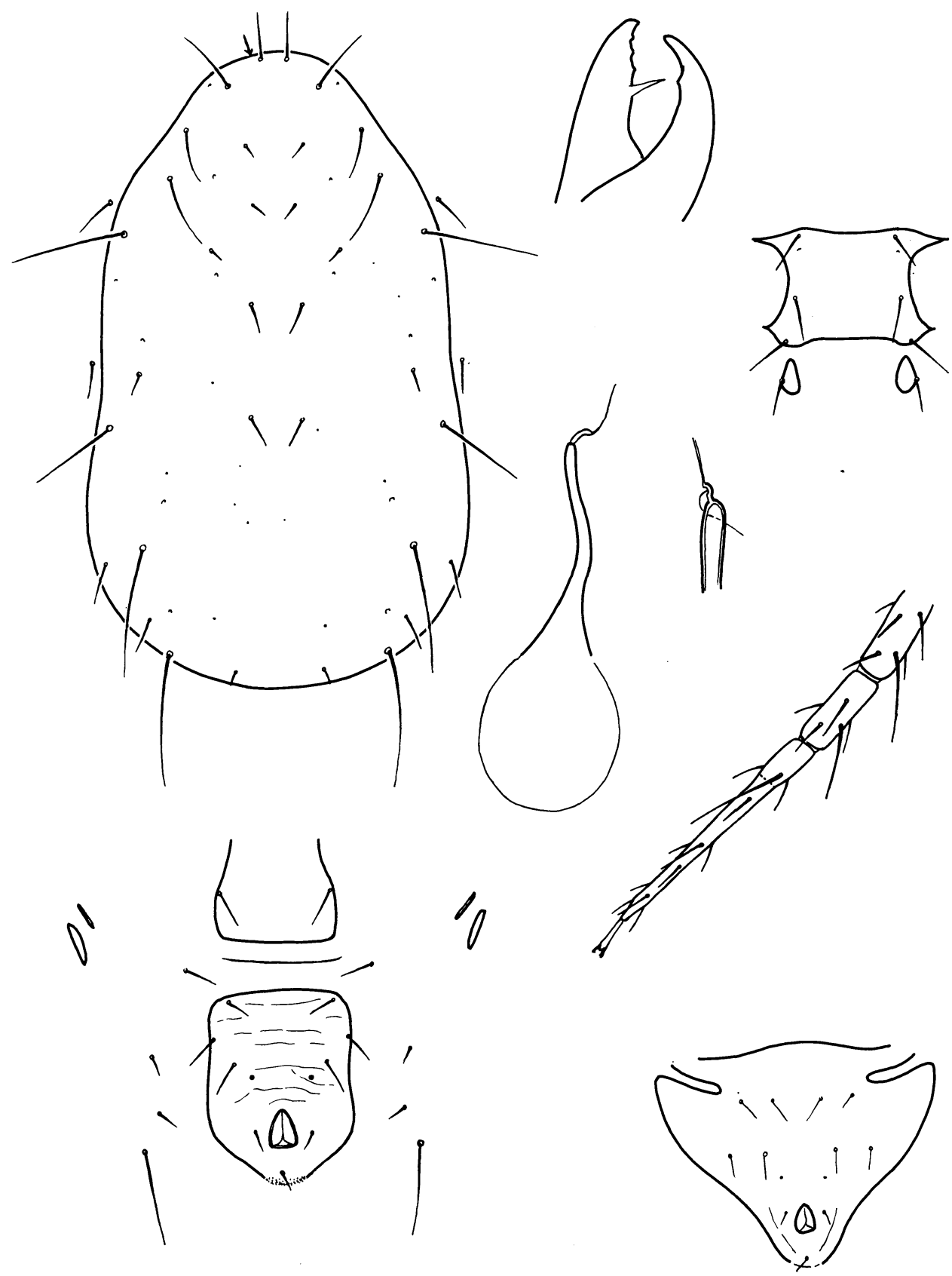

Fig. 30. Amblyseius ablusus, new species.

seta. Ventri-anal plate $93 \mu$ wide, $107 \mu$ long, with a tendency for reduction of anterolateral corners, frequently leaving one or two small detached platelets; with three pairs of preanal setae and with a pair of pores located ap- proximately between the third setae. Primary metapodal platelets $24 \mu$ long, $5 \mu$ wide, accessory platelets $13 \mu$ by $3 \mu$. Genital plate $68 \mu$ wide. Metasternal platelets distinct. Cervix and atrium of spermatheca, combined lengths, $17 \mu$. 

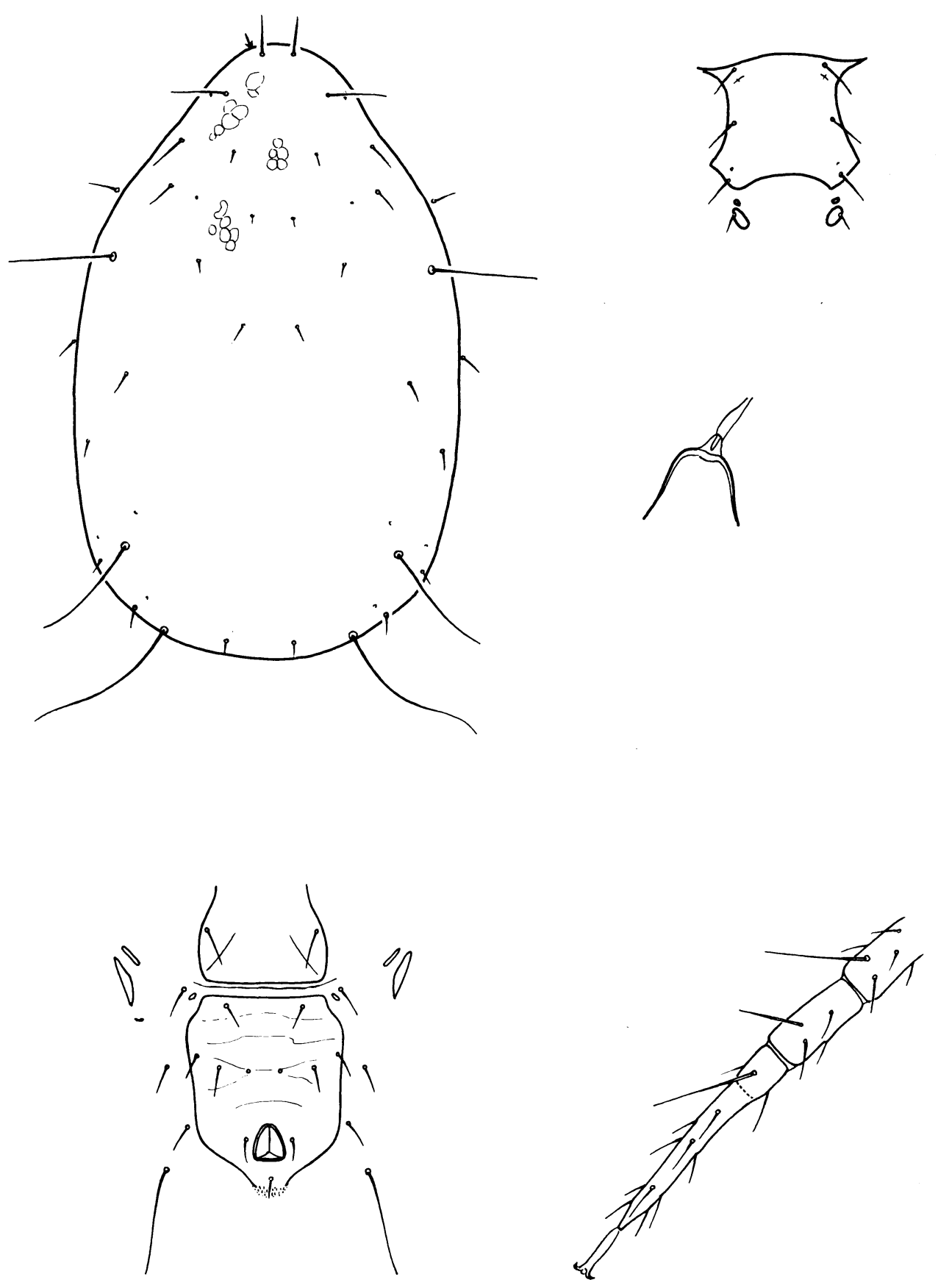

Fig. 31. Amblyseius asetus (Chant). 
Leg IV with macroseta on basitarsus $59 \mu$, on tibia $30 \mu$, on genu $51 \mu$; indistinct macrosetae on genua II and III. Male. Unknown.

\section{COLLECTION DATA}

Riverside County: Riverside, May 21, 1959 (C. L. Judson). Solano County: north side of Montezuma Slough near Grizzly Island, October 20, 1959 (R. O. Schuster). (Originally described from West Virginia and Texas.)

Taken from pecan litter and from a salt marsh.

\section{Amblyseius lindquisti, new species}

(Fig. 32)

Amblyseius lindquisti resembles $A$. oregonensis (Garman) except that the movable digit of the female chelicera is not multidentate. $A$. lindquisti has the postmediolateral setae shorter than postlateral setae $\mathrm{V}$ and the preanal pores well caudad to the preanal setae, distinguishing it from related species with similar dorsocentral, prolateral, and anterior postlateral setae.

Female. Chelicera with one prominent subapical tooth on fixed digit, anterior to pilus dentilis, and one small tooth on movable digit. Dorsal shield $415 \mu$ long, $320 \mu$ wide, with three pairs of dorsocentral setae. Vertical setae $34 \mu$, dorsocentrals $4 \mu$, clunals $13 \mu$; prolaterals I $52 \mu$, II $36 \mu$, III $14 \mu$, IV $100 \mu$; postlaterals I $9 \mu$, II $12 \mu$, III and IV $8 \mu, \mathrm{V} 200 \mu$; promediolaterals $8 \mu$, postmediolaterals $145 \mu$; sublaterals I $21 \mu$, II $15 \mu$; all setae simple. Peritreme extending forward beyond the base of prolateral seta I. Ventri-anal plate $155 \mu$ wide and $150 \mu$ long, with three pairs of preanal setae and with a pair of pores behind and slightly mediad to the caudad setae. Primary metapodal platelets $36 \mu$ long, $6 \mu$ wide; accessory platelets $8 \mu$ by $3 \mu$. Genital plate $120 \mu$ wide. Metasternal platelets large, elongate. Cervix of spermatheca
$25 \mu$ long, atrium $4 \mu$. Leg IV with macroseta on basitarsus $85 \mu$, on tibia $85 \mu$, on genu $100 \mu$.

Male. Unknown.

Holotype. Female, 3 miles northwest of Castroville, Monterey County, February 1, 1960 (E. E. Lindquist), from hay in barn; type no. 2785 in the U. S. National Museum.

Paratypes. Two females, data same as for holotype.

This species is named for Evert E. Lindquist.

\section{Amblyseius ovatus (Garman), new combination \\ (Fig. 33)}

Amblyseiopsis ovatus Garman, 1958, p. 78.

Typhlodromus (Amblyseius) ovatus (Garman). Chant, $1960 a$, p. 90.

The female of Amblyseius ovatus differs from related species with similar proscutal and anterior postscutal setae in that the postmediolateral setae are longer than postlateral setae $\mathrm{V}$.

Female. Dorsal shield $390 \mu$ long, $325 \mu$ wide, with three pairs of dorsocentral setae. Verticals $27 \mu$; dorsocentrals I and II $8 \mu$, III $14 \mu$; clunals $8 \mu$; prolaterals I $59 \mu$, II $40 \mu$, III $29 \mu$, IV $85 \mu$; postlaterals I-III $20 \mu$, IV $17 \mu$, $\mathrm{V}$ about $60 \mu$; promediolaterals $8 \mu$, postmediolaterals $90 \mu$; sublaterals I $25 \mu$, II $20 \mu$; all setae simple. Peritreme extending forward to base of vertical seta. Ventri-anal plate $121 \mu$ wide, $128 \mu$ long, with three pairs of preanal setae and with a pair of pores located between and only slightly behind the third setae. Primary metapodal platelets $37 \mu$ long, $10 \mu$ wide; accessory platelets $12 \mu$ by $4 \mu$. Three or four platelets near each of the anteriormost ventrolateral setae. Genital plate $125 \mu$ wide. Metasternal platelets large, subcircular. Cervix of spermatheca $25 \mu$ long, atrium $8 \mu$. Leg IV with macrosetae on basitarsus, tibia, and genu: longest on basitarsus and shortest on tibia.

Male. Unknown. 


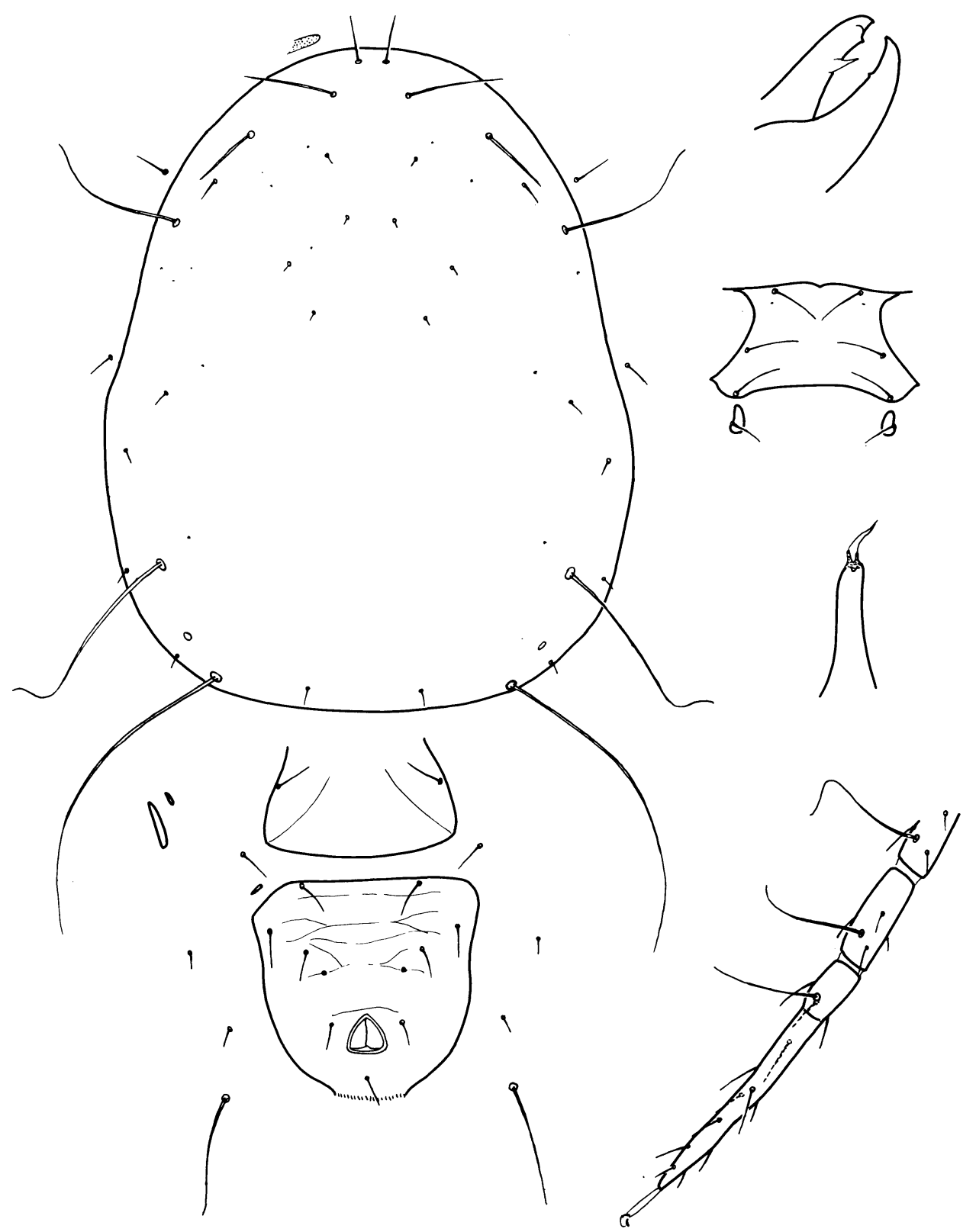

Fig. 32. Amblyseius lindquisti, new species.

\section{COLLECTION DATA}

Plumas County: 7 miles northwest of Chester, June 28, 1959 (E. E. Lindquist). (We have studied specimens from Albuquerque, New Mexico (July
8, 1959, B. E. Pullen); and from the Southwest Research Station, Chiricahua Mountains, Arizona (August 7, 1958, R. O. Schuster).)

Taken from grass and from soil near springs. 

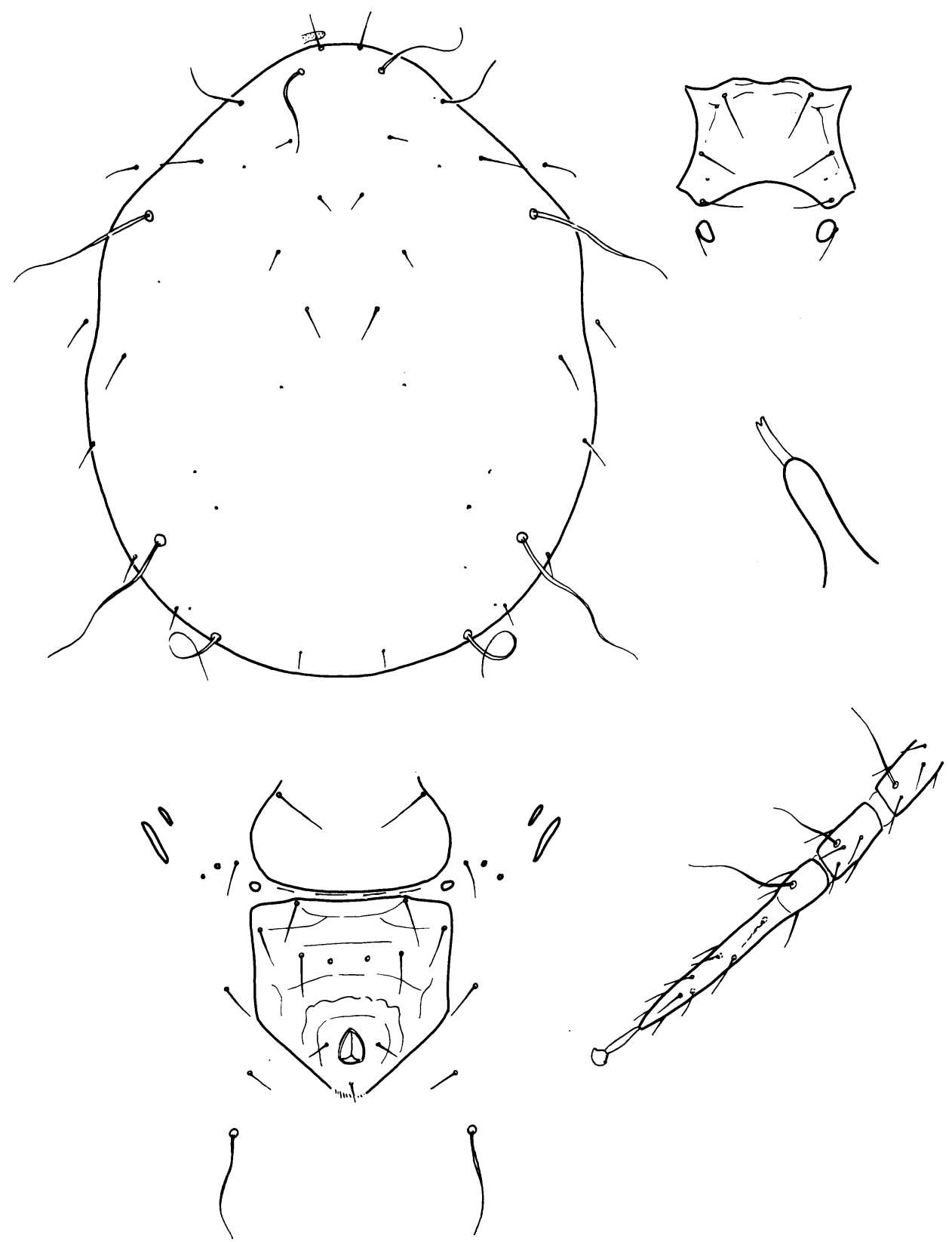

Fig. 33. Amblyseius ovatus (Garman).

15. Amblyseius fragariae Kennett

(Fig. 34)

Amblyseius fragariae Kennett, 1958, p. 475.

Typhlodromus (Amblyseius) fragariae (Kennett). Chant, $1960 a$, p. 89.

Amblyseius fragariae can be distinguished from $A$. neomexicanus by its longer prolateral setae III, and from $A$. exopodalis by its broader ventri-anal and genital plates.

Female. Chelicera with three or four subterminal teeth anterior to pilus dentilis on fixed digit, one small tooth on movable digit. Dorsal shield $400 \mu$ long, 
$315 \mu$ wide, with three pairs of dorsocentral setae. Vertical setae $25 \mu$; dorsocentrals I and II $8 \mu$, III $16 \mu$; clunals $8 \mu$; prolaterals I $72 \mu$, II $55 \mu$, III $28 \mu$, IV $87 \mu$; postlaterals I $30 \mu$, II $53 \mu$, III
$28 \mu$, IV $15 \mu$, V $80 \mu$; promediolaterals $8 \mu$, postmediolaterals $85 \mu$; sublaterals I $30 \mu$, II $22 \mu$; all setae smooth. Peritreme extending forward to base of vertical seta. Ventri-anal plate $130 \mu$

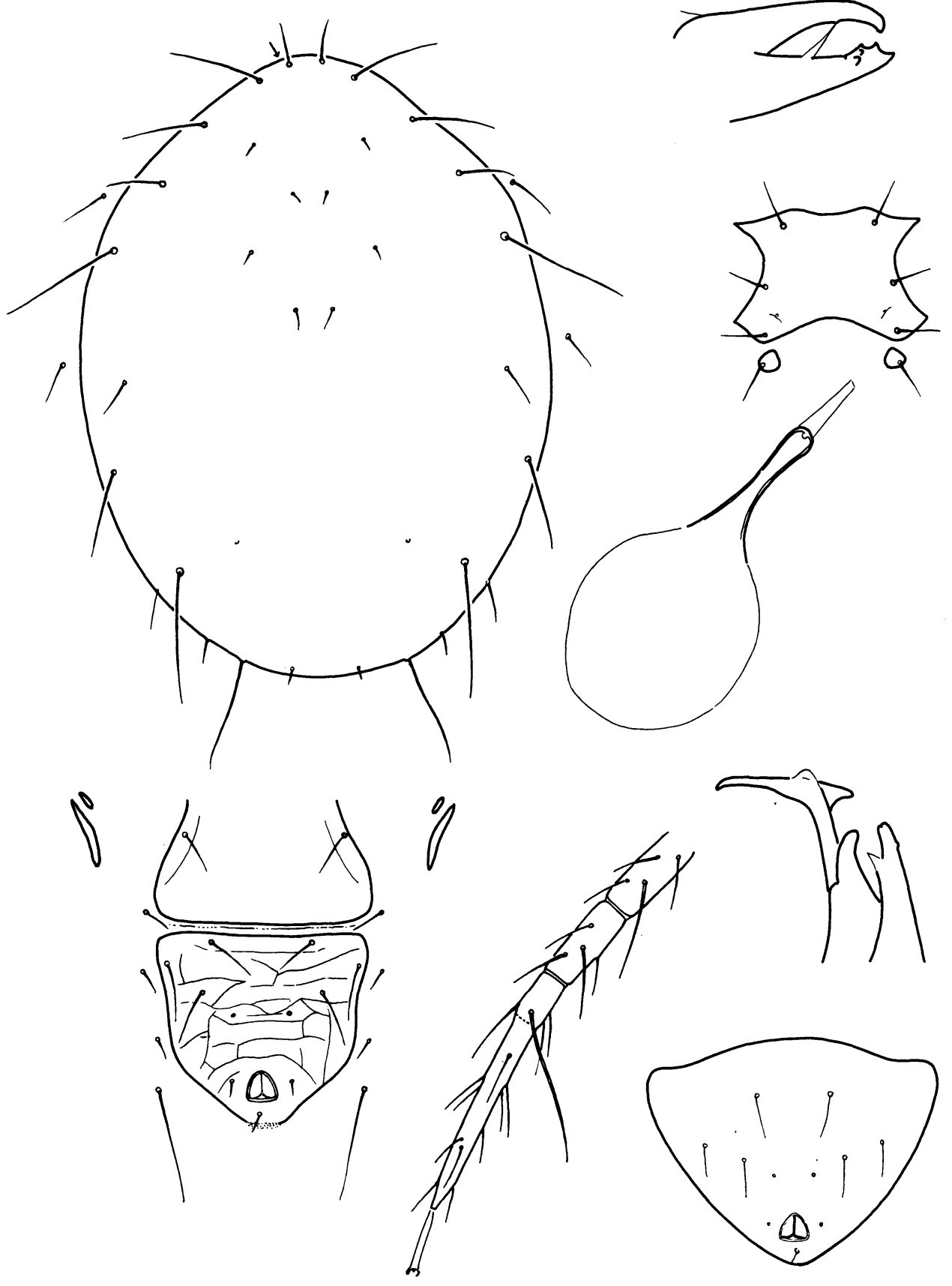

Fig. 34. Amblyseius fragariae Kennett. 
wide and $130 \mu$ long, with three pairs of preanal setae and a pair of pores. Primary metapodal platelets $35 \mu$ long, $6 \mu$, wide; accessory platelets $13 \mu$ by $3 \mu$. Genital plate $135 \mu$ wide. Metasternal platelets large, subcircular. Cervix and atrium of spermatheca, combined lengths, about $33 \mu$. Leg IV with macroseta on basitarsus $82 \mu$, on genu $50 \mu$.

Male. Dorsal shield $335 \mu$ long, $235 \mu$ wide. Ventri-anal plate with three pairs of preanal setae and a pair of pores.

\section{COLLECTION DATA}

Los Angeles County: near Covina, December 28, 1958 (L. M. Smith). Placer County: 4 miles west of Newcastle, January 3 and March 10, 1959 (L. M. Smith, R. O. Schuster). RIVERSide County: Riverside, November 30, 1958 (C. L. Judson). Sacramento County: Carmichael, February 19, 1959 (R. F. Wilkey). SAN JoAQUIN County: Terminous, November 25, 1958 (A. A. Grigarick). SANTA BarBara County: San Marcos Pass, December 24, 1958 (L. M. Smith). SANTA Clara County: Coyote (type specimen). Sonoma County: 8 miles west of Santa Rosa, November 12, 1958 (W. H. Lange, H. L. McKenzie). Tehama County: Post Pile Camp, at 5,800 feet, August 30, 1960 (A. A. Grigarick, R. O. Schuster). Yolo County: Davis, December 7, 1958 (F. C. Raney) ; 2 miles north of Davis, November 30, 1958 (R. O. Schuster); 5.4 miles southwest of Winters, May 29, 1959 (L. M. Smith, R. O. Schuster, F. C. Raney).

Found in litter beneath Carya, Ceanothus, Fragaria, Medicago sativa, Photinia, Populus, Pyracantha, and Quercus wislizenii.

\section{Amblyseius exopodalis Kennett (Fig. 35)}

Amblyseius exopodalis Kennett, 1958, p. 476. Typhlodromus (Amblyseius) exopodalis (Kennett). Chant, $1960 a$, p. 90.

Amblyseius exopodalis resembles $A$. fragariae but is easily distinguished by its narrower ventri-anal and genital plates. The third prolateral setae are subject to variation in length, but are never longer than the second prolateral setae of the specimen, and are usually much shorter. Similarly, the first postlateral setae are no longer than the distances between their bases and those of the second postlateral setae, and are usually much shorter. A fourth pair of dorsocentral setae may be absent or represented by either one or both setae. Narrow transverse platelets anterior to the ventri-anal plate may be present or absent. The cervix of the spermatheca is typically slender, narrowing medially, but is subject to great variation in relative length and shape. Biological studies may be needed to determine the exact status of this species.

Female. Chelicera with four teeth plus pilus dentilis on fixed digit, one tooth on movable digit. Dorsal shield faintly reticulate, $370 \mu$ long, $235 \mu$ wide, with three-occasionally four-pairs of dorsocentral setae. Vertical setae $30 \mu$, dorsocentrals $17 \mu$, clunals $13 \mu$; prolaterals I $38 \mu$, II $35 \mu$, III $24 \mu$, IV $63 \mu$; postlaterals I $19 \mu$, II $42 \mu$, III and IV about $15 \mu, \mathrm{V} 100 \mu$; promediolaterals $13 \mu$, postmediolaterals $84 \mu$; sublaterals I $30 \mu$, II $22 \mu$; postlateral setae V definitely but weakly serrate. Peritreme extending forward to base of vertical seta. Ventri-anal plate $95 \mu$ wide, $120 \mu$ long, with three pairs of preanal setae and with a pair of pores between and slightly behind third setae. Primary metapodal platelets $21 \mu$ long, $6 \mu$ wide; accessory platelets $14 \mu$ by $3 \mu$. Genital plate $78 \mu$ wide. Metasternal platelets distinct. Cervix of spermatheca $20 \mu$ long, atrium 3-4 . Leg IV with macroseta on basitarsus $74 \mu$, on genu $57 \mu$.

Male. Dorsal shield $280 \mu$ long, $200 \mu$ wide. Ventri-anal plate with six pairs of preanal setae and two pairs of pores.

\section{COLLECTION DATA}

Butte County: Chico, September 4, 1958 (R. O. Schuster). Marin County: Bolinas, March 24, 1960 (R. O. Schus- 


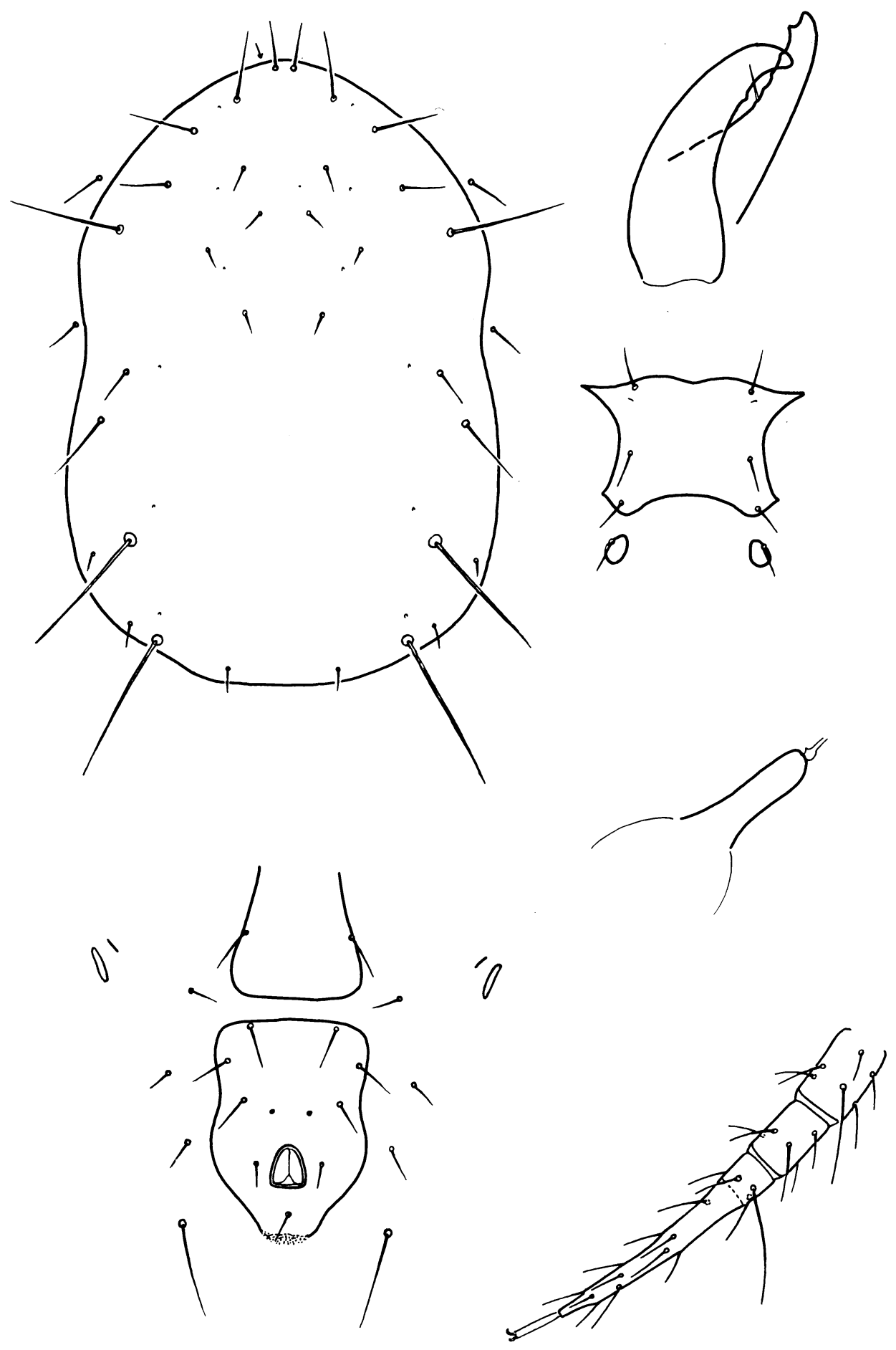

Fig. 35. Amblyseius exopodalis Kennett. 
ter). Napa County: Napa, December 22, 1959 (R. O. Schuster). Orange County: Laguna Beach, June 13, 1960 (H. L. McKenzie). San Diego County: Encinitas, June 13, 1960 (H. L. McKenzie). Solano County: north side of Montezuma Slough near Grizzly Island, October 20, 1959 (R. O. Schuster). Tulare County: 1 mile east of Lemoncove, May 13, 1959 (L. M. Smith). Yolo County: Knights Landing, September 27, 1960 (H. L. McKenzie) ; 3 miles north of Rumsey, November 3, 1959 (A. A. Grigarick).

Found on foliage of Cynodon dactylon and in litter of Anemopsis, Quercus, Salix, Umbellularia, and of mixed $D i$ stichlis, Mesembryanthemum, and Salicornia.

\section{Amblyseius newelli (Chant), new combination}

(Fig. 36)

Typhlodromus (Amblyseins) newelli Chant, $1960 b$, p. 135.

Distinguishing characters of this species are the lengths of prolateral setae II and III relative to each other and to the dorsocentral setae, the occurrence of macrosetae at postlateral positions II and $\mathrm{V}$, and the location of the third pair of sternal setae on separate plates.

Female. Fixed digit of chelicera with nine minute teeth, movable digit with one or two blunt subapical teeth. Dorsal shield $427 \mu$ long, $259 \mu$ wide, with four pairs of dorsocentral setae. Vertical setae $37 \mu$, dorsocentrals about $10 \mu$, clunals $13 \mu$; prolaterals I $60 \mu$, II and III $44 \mu$, IV $92 \mu$; postlaterals I $10 \mu$, II $92 \mu$, III and IV $13 \mu$, V $134 \mu$; promediolaterals $10 \mu$, postmediolaterals $121 \mu$; sublaterals I and II $27 \mu$; all setae simple. Peritreme extending forward to base of vertical seta. Ventri-anal plate $144 \mu$ long, $111 \mu$ wide, widest across posterior third, with sides either emarginate or straight, with three pairs of preanal setae, and with a pair of pores directly behind third setae. Primary metapodal platelets $34 \mu$ long, $8 \mu$ wide; accessory platelets $17 \mu$ by $5 \mu$. Genital plate $92 \mu$ wide. Sternal plate with two pairs of setae, third pair of sternal setae on separate platelets; metasternal platelets distinct. Cervix of spermatheca $16 \mu$ long, atrium $3 \mu$. Leg IV with macroseta on basitarsus $67 \mu$, on tibia $67 \mu$, on genu $74 \mu$.

Male. Unknown.

\section{COLLECTION DATA}

Marin County: Black Point, March 24, and near Bolinas, June 7, 1960 (R. O. Schuster). (Specimens from Alameda, Los Angeles, and Sonoma counties, collected between 1953 and 1957, were cited by Chant (1960b).)

Found on foliage of Magnolia and in mixed Quercus and Umbellularia litter.

\section{Amblyseius neomexicanus (Chant), new combination}

(Fig. 37)

Amblyseiopsis reticulatus Garman, 1958, p. 77 [not Amblyseius reticulatus (Oudemans)]. Typhlodromus (Amblyseius) neomexicanus Chant, $1960 a$, p. 89.

The spermatheca, in which the atrium does not appear as a separate entity, is an excellent character for distinguishing this species. Prolateral setae III of this species are shorter and postlateral setae II are longer than those setae in A. exopodalis.

Female. Chelicera about $37 \mu$ long: fixed digit with three teeth between pilus dentilis and apex, movable digit without teeth. Dorsal shield $395 \mu$ long, $330 \mu$ wide, with three pairs of dorsocentral setae. Vertical setae $29 \mu$; dorsocentrals I and II $8 \mu$, III $12 \mu$; clunals $10 \mu$; prolaterals I and II $50 \mu$, III $16 \mu$, IV $93 \mu$; postlaterals I $8 \mu$, II $87 \mu$, III and IV $16 \mu, \mathrm{V} 87 \mu$; promediolaterals $8 \mu$, postmediolaterals $95 \mu$; sublaterals I $30 \mu$, II $10 \mu$; all setae smooth. Peritreme extending forward to base of vertical seta. Ventri-anal plate $125 \mu$ wide and $140 \mu$ long, often with some recession of anterolateral margins, leaving one or two small, separate platelets; with three pairs of preanal setae and with a pair of pores almost in line with third pair of setae. Pri- 


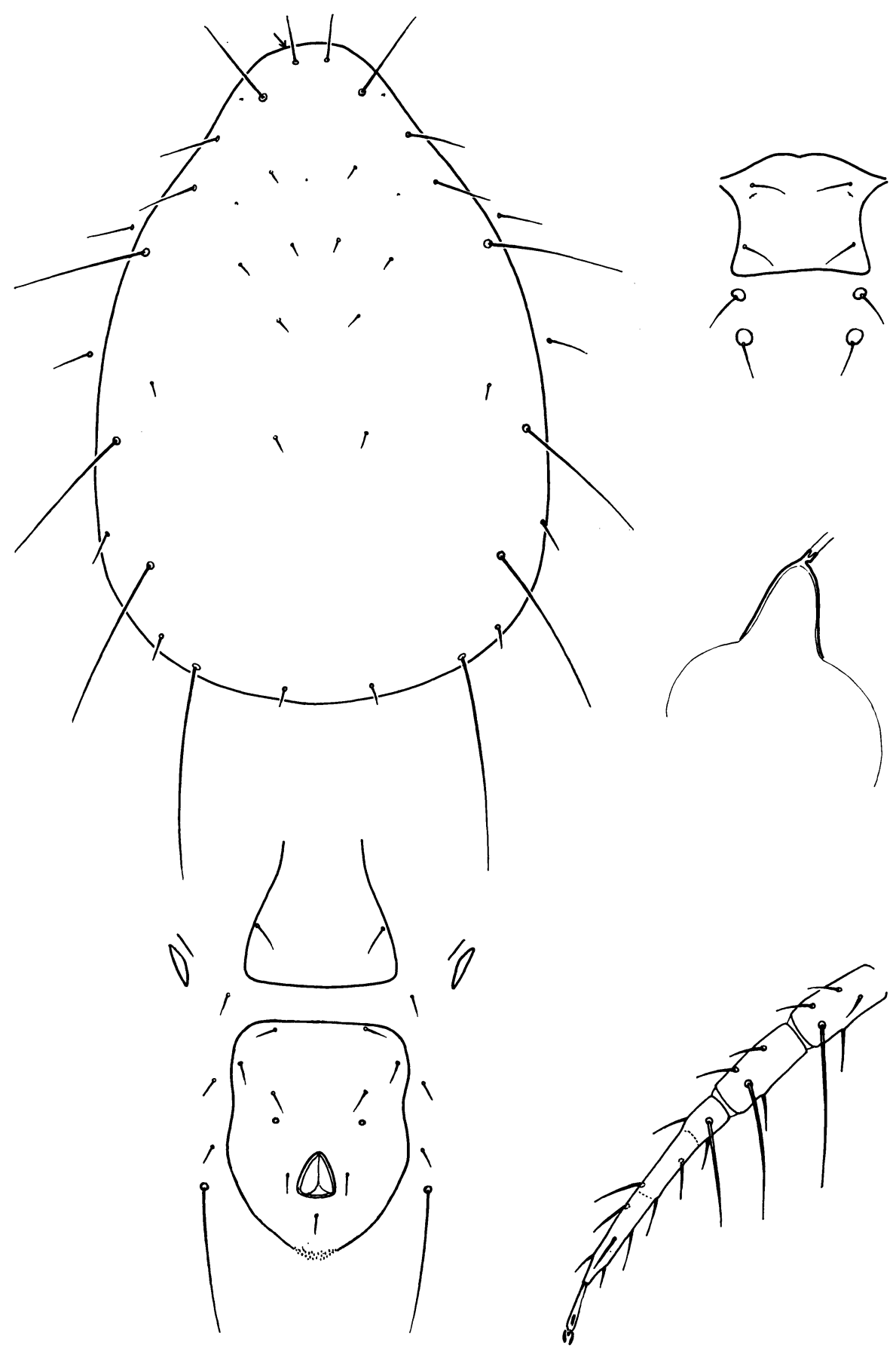

Fig. 36. Amblyseius newelli (Chant). 


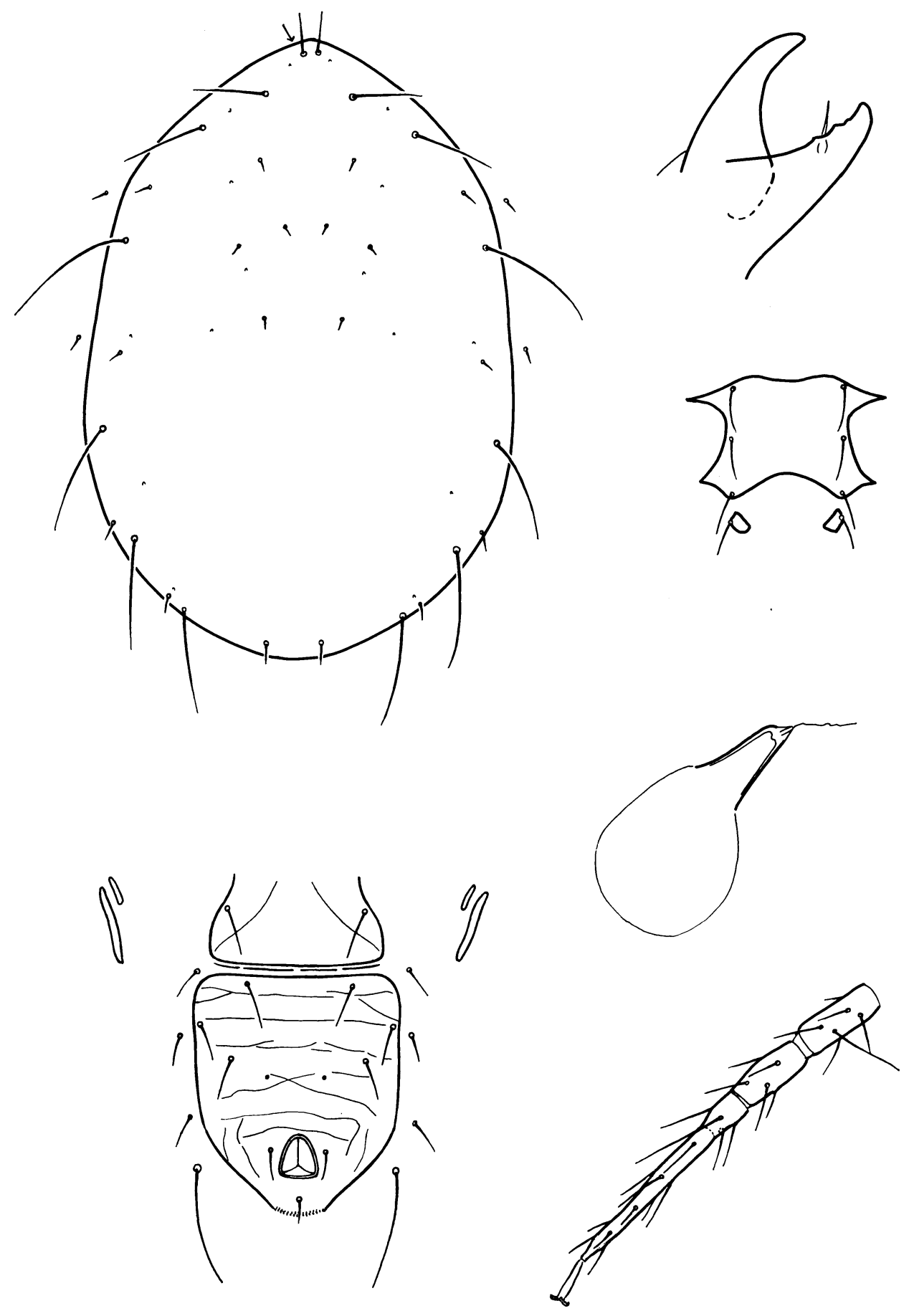

Fig. 37. Amblyseius neomexicanus (Chant). 
mary metapodal platelets $40 \mu$ long, $6 \mu$ wide; accessory platelets $20 \mu$ by $3 \mu$. Genital plate $103 \mu$ wide. Metasternal platelets large. Cervix of spermatheca $20 \mu$ long, atrium about $4 \mu$ long. Leg IV with macroseta on basitarsus $60 \mu$, on tibia $30 \mu$, on genu $45 \mu$.

Male. Unknown.

\section{COLLECTION DATA}

Amador County: Fiddletown, March 21, 1959 (L. M. Smith). Contra Costa County: 1 mile south of intersection of Marsh Creek and Morgan Territory roads, May 26, 1959, Mount Diablo State Park, July 10, 1958, and Mount Diablo, May 26, 1959 (all by L. M. Smith, R. O. Schuster). Fresno County: 10 miles west of Kings Canyon Ranger Station, July 26, 1956 (R. O. Schuster). Marin County: Black Point, and near Bolinas, March 20 and 24, 1960 (R. O. Schuster). NAPA County: 9 miles south of Monticello, November 11, 1956; Napa, February 3, 1959 (R. O. Schuster); 3 miles northnortheast of Saint Helena, December 15, 1958 (F. C. Raney). Placer County: 4 miles west of Newcastle, March 10 , 1959 (L. M. Smith, R. O. Schuster). San Diego County: near Cuyamaca Lake, December 26, 1958, and 10 miles east of Julian, March 26, 1959 (L. M. Smith). SaN Mateo County: Cahill Ridge, May 7 and June 11, 1960 (D. W. Price); near Crystal Springs Reservoir, March 29, 1960 (S. F. Bailey) ; Sweeney Ridge, 3 miles south of San Francisco County Jail, October 2, 1960 (D. W. Price). Solano County: 14 miles north of Vacaville, December 1, 1956 (R. O. Schuster). Sonoma County: near Maacama Creek, February 3, 1959 (R. O. Schuster); 2 miles west of Petrified Forest, and in Santa Rosa, October 25, 1959 (J. S. Buckett). Tulare County: 1 mile east of Lemoncove, May 13, 1959 (L. M. Smith). Yolo County: Davis, May 1, 1957 (R. O. Schuster); 3 miles north of Rumsey, July 29, 1959 (L. M. Smith, R. O. Schuster);
5.4 miles south of Winters, April 23, 1959 (F. C. Raney).

Found in litter beneath Aesculus, Alnus rhombifolia, Arbutus, Photinia, Pinus sp., Prunus domestica, Pseudotsuga taxifolia, Quercus agrifolia, $Q$. lobata, Q. wislizenii, Rhus diversiloba, Rubus, Salix, and Umbellularia californica, in compost of manure and Umbellularia, and on a tide flat. Prey unknown.

\section{Amblyseius inornatus, new species} (Fig. 38)

Amblyseius inornatus is closely allied to $A$. ornatus Athias-Henriot, but the dorsal shield lacks the characteristic punctation of that species, and the cervix of the spermatheca is not triangular but longer than wide and broadly rounded distally.

Female. Chelicera about $34 \mu$ long. Dorsal shield $395 \mu$ long, $280 \mu$ wide, faintly reticulate, with four pairs of dorsocentral setae. Vertical setae $29 \mu$; dorsocentrals I and II $26 \mu$; III and IV $31 \mu$; clunals $13 \mu$; prolaterals I $43 \mu$; II $37 \mu$, III $41 \mu$, IV $59 \mu$; postlaterals I $42 \mu$, II $59 \mu$, III and IV $31 \mu, \mathrm{V} 77 \mu$; promediolaterals $19 \mu$, postmediolaterals $75 \mu$; sublaterals I and II $34 \mu$; postmediolaterals and postlaterals $\mathrm{V}$ very faintly serrate. Peritreme extending forward to base of vertical seta. Ventri-anal plate $125 \mu$ wide, $145 \mu$ long-in some specimens only $135 \mu$ long, more rounded, with anterolateral margins subject to reduction-with three pairs of preanal setae and with a pair of pores behind and slightly mediad to setae. Primary metapodal platelets $34 \mu$ long, $5 \mu$ wide; accessory platelets $15 \mu$ by $3 \mu$. Genital plate $97 \mu$ wide; metasternal platelets distinct. Cervix of spermatheca $13 \mu$ long, atrium $4-5 \mu$. Leg IV with macroseta on basitarsus $67 \mu$, on genu $51 \mu$.

Male. Unknown.

Holotype. Female, Soda Springs Resort, Nevada County, May, 1959 (F. C. Raney), on Veratrum californicum; 


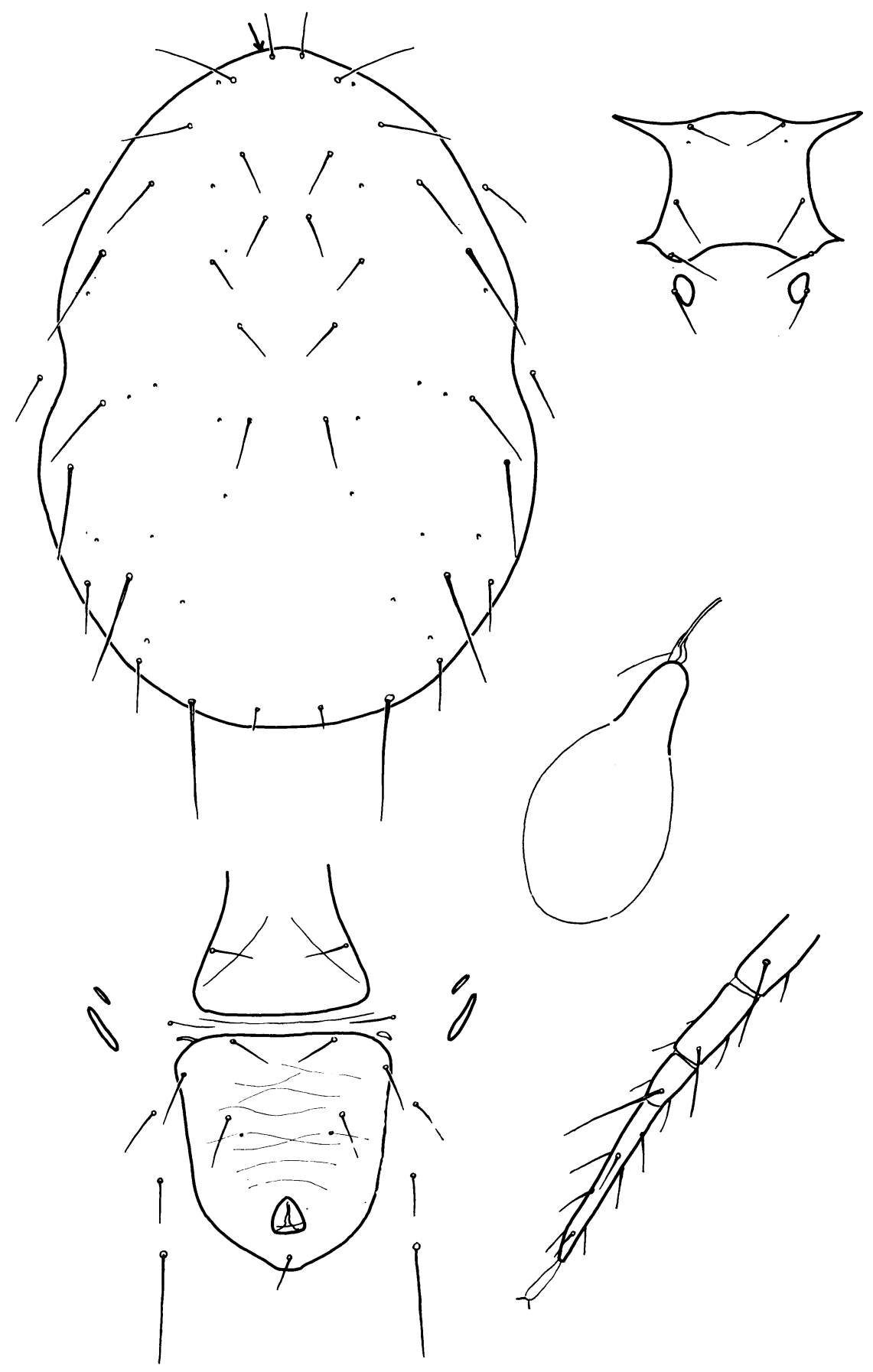

Fig. 38. Amblyseius inornatus, new species. 
type no. 2786 in the U. S. National Museum.

Paratypes. Two females, data same as for holotype; one female, Tuolumne Meadows, Tuolumne County, June 20, 1957 (D. W. Price), from pine soil; two females from north side of Montezuma Slough near Grizzly Island, Solano County, October 20, 1959 (R. O. Schuster), from foliage in a plant association of Distichlis spicata, Mesembryanthemum, and Salicornia ambigua.

\section{Amblyseius fallacis (Garman)} (Fig. 39)

Iphidulus fallacis Garman, 1948, p. 13.

Typhlodromus fallacis (Garman). Nesbitt, 1951, p. 24.

Amblyseius fallacis (Garman). Athias-Henriot, 1958, p. 34.

Typhlodromus (Amblyseins) fallacis (Garman). Chant, 1960a, p. 74.

In our fauna, this and Amblyseius inornatus are the only species of $\mathrm{Am}$ blyseius with postlateral setae I of sufficient length to reach the bases of postlateral setae II. A. fallacis is further distinguished by the shape of the spermatheca, by the crescentic preanal pores, and by the occurrence of the macroseta of leg IV on basitarsus only.

Female. Chelicera with one subapical tooth on fixed digit, movable digit apparently smooth. Dorsal shield $400 \mu$ long, $200 \mu$ wide, reticulate, with four pairs of dorsocentral setae. Vertical setae $24 \mu$; dorsocentrals I $46 \mu$, II $40 \mu$, III $46 \mu$, IV $54 \mu$; prolaterals I-III $50 \mu$, IV $67 \mu$; postlaterals I $52 \mu$, II $62 \mu$, III $51 \mu$, IV $40 \mu$, V $76 \mu$; promediolaterals $29 \mu$, postmediolaterals $66 \mu$; sublaterals I $28 \mu$, II $34 \mu$; postmediolaterals and postlaterals $\mathrm{V}$ serrate. Peritreme extending forward nearly to vertical seta. Ventri-anal plate $110 \mu$ wide, $125 \mu$ long, with three pairs of preanal setae and with a pair of crescentic pores between and behind the third setae. Primary metapodal platelets $27 \mu$ long, $6 \mu$ wide; accessory platelets $12 \mu$ by $2 \mu$. Genital plate $85 \mu$ wide. Sternal plate with two or three pairs of setae, third pair sometimes on separate platelets; metasternal platelets distinct. Cervix of spermatheca $15 \mu$, atrium $2-3 \mu$. Leg IV with macroseta on basitarsus $60 \mu$.

Male. Unknown.

\section{COLLECTION DATA}

Glenn County: June 15, 1953 (W. W. Allen). Monterey County: King City, November 25, 1955. Stanislaus County: Salida, September 10, 1959 (A. E. Pritchard). Yolo County: Davis, September 27, 1957 (E. C. Carlson), and October 7, 1957 (R. O. Schuster).

Found on bermudagrass, kidney bean, ladino clover, Malva, and soy bean. Prey includes Tetranychus pacificus and T.telarius.

\section{Amblyseius desertus (Chant), new combination}

(Fig. 40)

Typhlodromus desertus Chant, 1957a, p. 294. Typhlodromus (Amblyseius) desertus Chant. Chant, $1960 a$, p. 76.

We have not seen the type specimen of Amblyseius desertus. California specimens do not match the published illustrations exactly, and some important characters are omitted from the original description. However, the California mites are sufficiently close to $A$. desertus to preclude our proposing a new species until the California form can be compared with the type specimen or with a better description of it. The description given below is based on one of the specimens collected in California.

Female. Chelicera with two subapical teeth and pilus dentilis on fixed digit, one small tooth on movable digit. Dorsal shield $375 \mu$ long, $250 \mu$ wide, strongly reticulate, with four pairs of dorsocentral setae. Vertical setae $22 \mu$, dorsocentrals $13-15 \mu$, clunals $8 \mu$; prolaterals I $19 \mu$, II-IV $18 \mu$; postlaterals I $16 \mu$, II and III $18 \mu$, IV $17 \mu, \mathrm{V} 44 \mu$; promediolaterals $13 \mu$, postmediolaterals $31 \mu$; sublaterals I $18 \mu$, II $13 \mu$ (sublaterals II may occur on the dorsal shield or on the lateral membrane). Peritreme extending beyond base of prolateral seta II. Ventri-anal plate $77 \mu$ wide, $124 \mu$ long, 

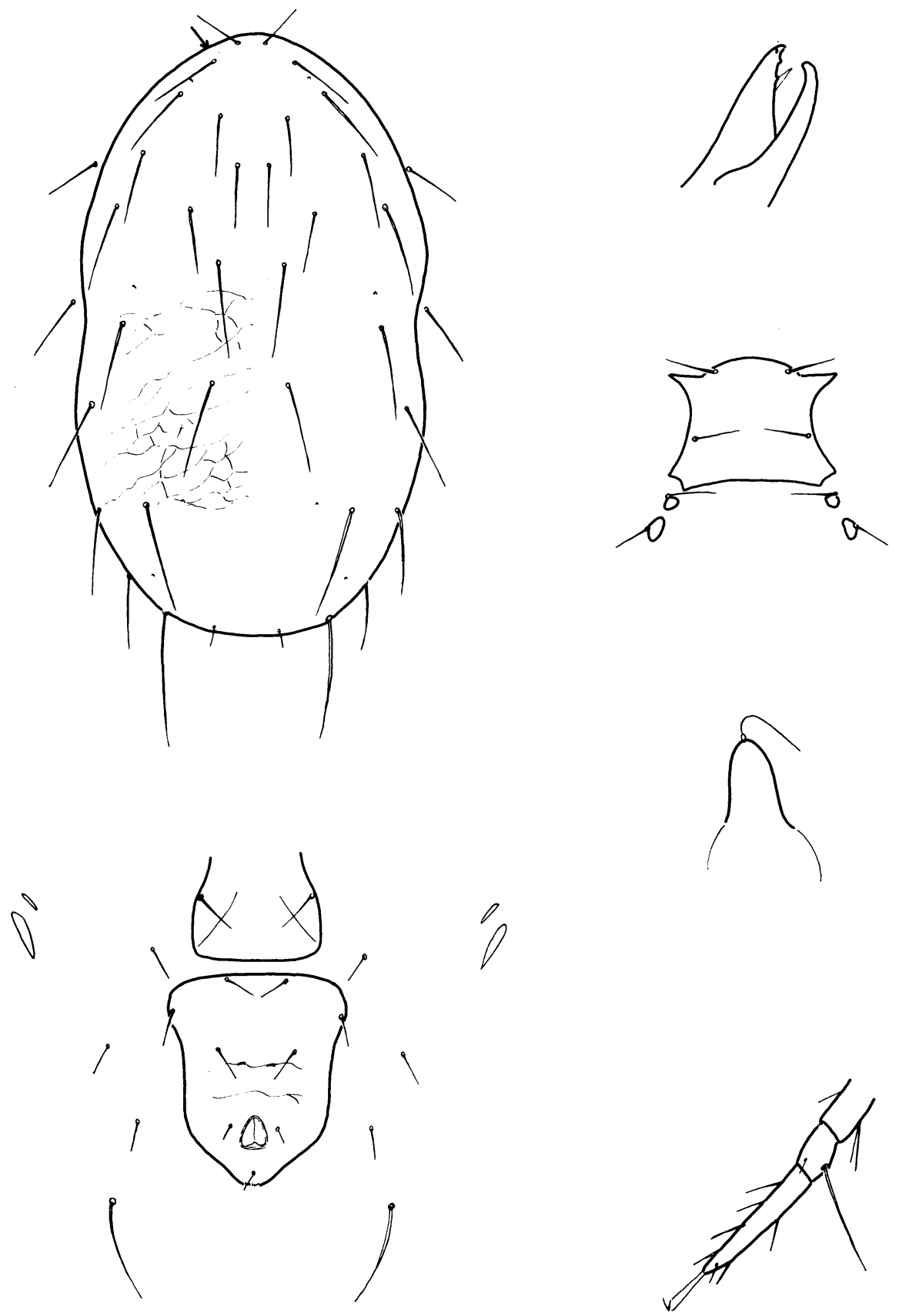

Fig. 39. Amblyseius fallacis (Garman).

with three pairs of preanal setae and with a pair of pores directly behind the third setae. Three pairs of ventrolateral setae and a number of small platelets around ventri-anal plate. Primary metapodal platelets $47 \mu$ long, $5 \mu$ wide; accessory platelets $18 \mu$ by $3 \mu$. Genital plate $77 \mu$ wide. Sternal plate indistinct, but with three pairs of setae; metasternal setae on small but distinct platelets. 

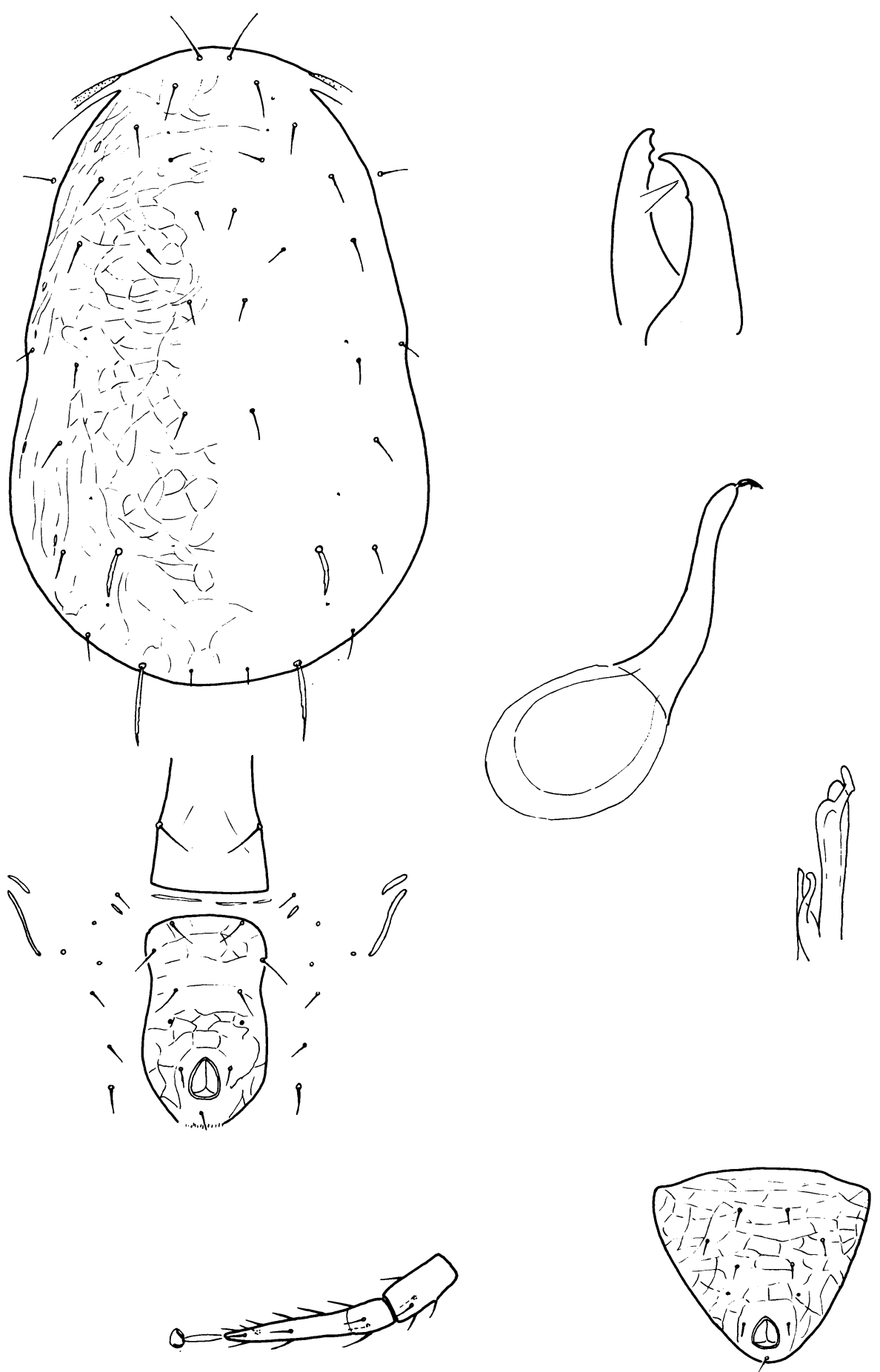

Fig. 40. Amblyseius desertus (Chant). 

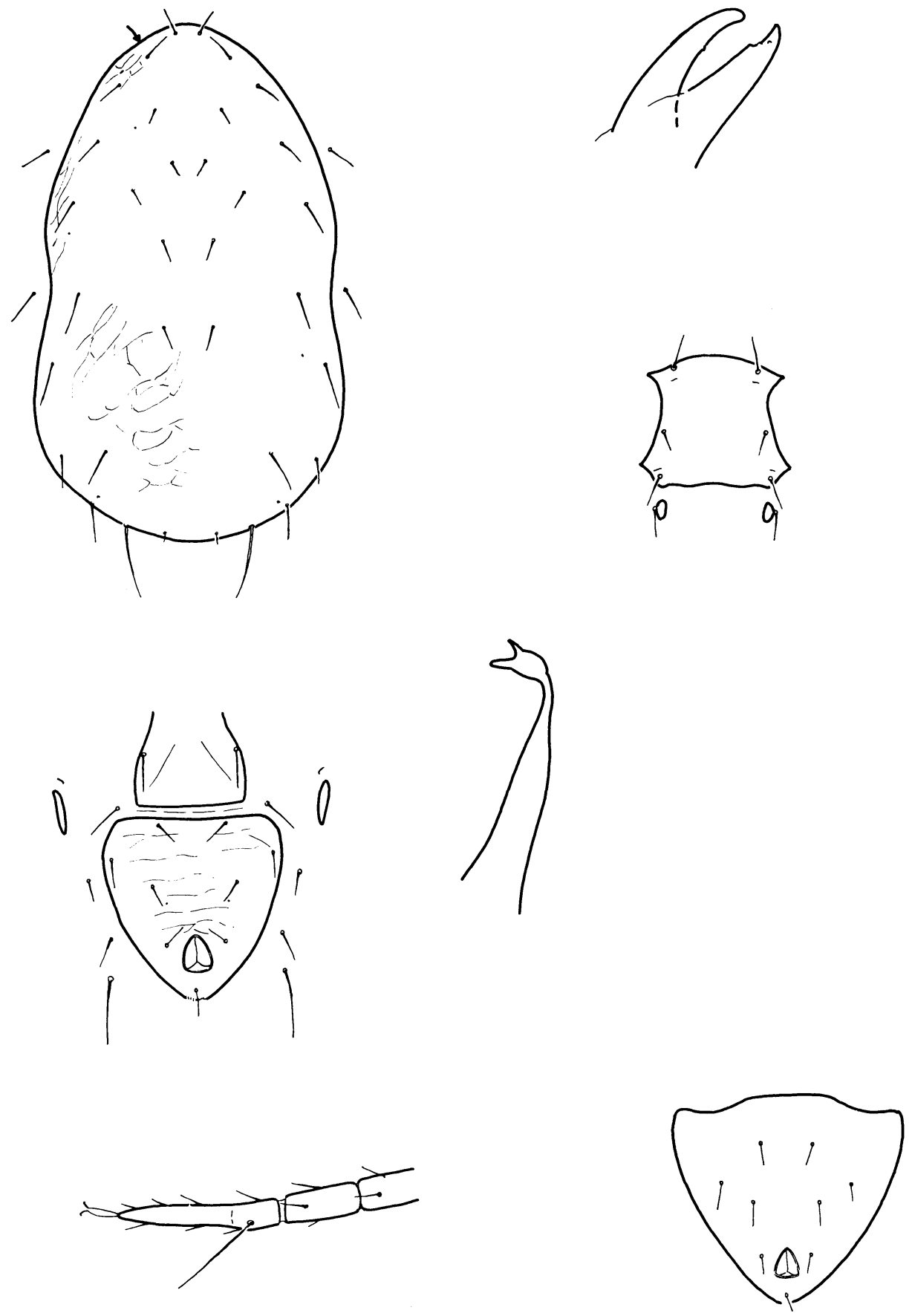

Fig. 41. Amblyseius aurescens Athias-Henriot. 
Cervix of spermatheca $34 \mu$ long; atrium thin, about $4 \mu$ long. Leg IV without macrosetae.

Male. Ventri-anal plate with three pairs of preanal setae and a pair of pores, behind and slightly laterad to the third setae.

\section{COLLECTION DATA}

Contra Costa County: Alamo, August 2, 1959 (B. E. Pullen). (Originally described from western Canada.)

Found on Salix.

\section{Amblyseius aurescens Athias-Henriot}

(Fig. 41)

Amblyseius aurescens Athias-Henriot, 1961, p. 441.

This mite was identified by Chant (1960a), Kennett (1958), Womersley (1954) and, perhaps, others as Amblyseius reticulatus (Oudemans). In view of Oudemans' (1930) description of the "two internal bladders with the bellshaped intermediate piece" and of Nesbitt's (1951) illustration of this structure, it is clear that Oudemans was dealing with a different species.

Superficially, Amblyseius aurescens resembles $A$. brevispinus. However, the dorsum is more heavily sclerotized and reticulate, and the shape of the spermatheca is distinctive.

Female. Chelicera with two minute subapical teeth plus pilus dentilis on fixed digit, movable digit smooth or with one minute tooth. Dorsal shield $335 \mu$ long, $185 \mu$ wide, heavily sclerotized, reticulate, with four pairs of dorsocentral setae. Verticals $11 \mu$; dorsocentrals I-III $15 \mu$, IV $17 \mu$; clunals $10 \mu$; prolaterals I $19 \mu$, II $17 \mu$, III $19 \mu$, IV $25 \mu$; postlaterals I $19 \mu$, II and III $26 \mu$, IV $25 \mu, \mathrm{V} 48 \mu$; promediolaterals $13 \mu$, postmediolaterals $34 \mu$; sublaterals I and II $18 \mu$; all setae simple. Peritreme extending forward to base of prolateral seta I. Ventri-anal plate $100 \mu$ wide, $120 \mu$ long, with three pairs of preanal setae; preanal pores weak or lacking. Venter with three pairs of ventrolateral setae.
Primary metapodal platelets $25 \mu$ long, $4 \mu$ wide; accessory platelets $10 \mu$ by $2-3 \mu$. Genital plate $72 \mu$ wide. Sternal plate with three pairs of setae and two pairs of pores; metasternal platelets of moderate size, distinct. Cervix of spermatheca $31 \mu$ long, constricted before large, bifid atrium, $13 \mu$ long. Leg IV with macroseta on basitarsus $56 \mu$.

Male. Ventri-anal plate with three pairs of preanal setae, usually lacking preanal pores.

\section{COLLECTION DATA}

Alameda County: Berkeley, June 30 and July 29 and 31, 1959 (B. E. Pullen). Contra Costa County: 5 miles east of Clayton, October 8, 1952 (J. W. MacSwain); Mount Diablo State Park, August 22, 1959 (B. E. Pullen). MarIN County: Bolinas, March 24, 1960 (R. O. Schuster); 1 mile west of Bolinas, January 19, 1960 (C. L. Judson). NAPA County: Mount Eden Vineyard, June 23, 1958 (R. O. Schuster) ; Napa, June 3, 1958 (J. J. Skelsey). Nevada County: Grass Valley, October 15, 1956. Riverside County: Riverside, November 30, 1958, and May 21, 1959 (C. L. Judson). Sacramento County: Florin, November 20, 1952 (W. W. Allen). San Joaquin County: Lodi, December 3, 1958 (R. O. Schuster). Santa Barbara County: Santa Maria, May 5, 1954 (C. E. Kennett). Santa Clara County: Berryessa, February 6, 1952 (W. W. Allen); Gilroy, January 12, 1955; San Jose, May 1, 1934 (L. M. Smith) and February, 1952 (C. B. Huffaker); Santa Clara, June, July, and August, 1952 (W. W. Allen). Santa Cruz County: Soquel, various dates, 1952 and 1953 (W. W. Allen). Solano County: north side of Montezuma Slough near Grizzly Island, October 20, 1959, and July 8, 1960 (R. O. Schuster). Sonoma County: Guerneville, May 30, 1960 (C. L. Judson); 8 miles west of Santa Rosa, September 12, 1958 (W. H. Lange, H. L. McKenzie). StanIslaus County: Modesto, September 10, 1959 (A. E. Pritchard). YoLo 

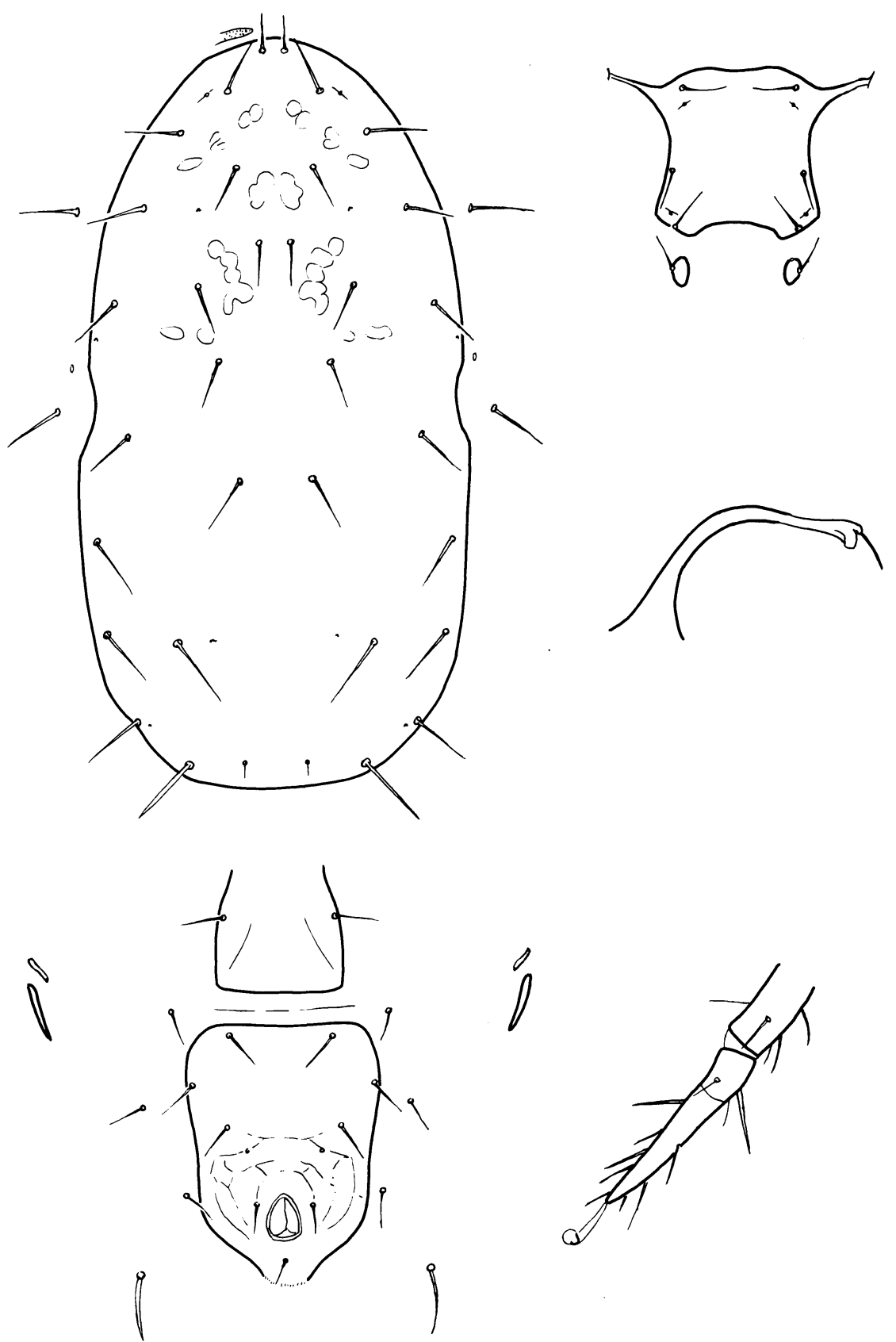

Fig. 42. Amblyseius loxus, new species.

County: 2 miles north of Davis, No- Taken from Cynodon dactylon, Fravember 30, 1958 (R. O. Schuster); 3 garia hybrida, Peumus boldus, Planmiles north of Rumsey, November 3, tago lanceolata and Poa (mixed), Pru1959 (W. H. Lange, A. A. Grigarick); nus domestica, Vitis; winter rye; litter 4 miles north of Rumsey, June 3, 1960 (R. O. Schuster). of Acer, Carya, Cupressus, Medicago sativa, and Salix. 
This mite is frequently collected with Amblyseius brevispinus. Although in California it seems to be restricted to litter and low-growing vegetation, we have seen apparently identical Australian forms from apple. Prey includes Eriophyes vitis and Steneotarsonemus pallidus.

\section{Amblyseius loxus, new species}

(Fig. 42)

This species is closely related to $\mathrm{Am}$ blyseius brevispinus but has longer, thicker dorsal setae. Also, the macroseta of the basitarsus of leg IV is only $34 \mu$ long but very thick, whereas in $A$. brevispinus it is $50 \mu$ long and very thin. Postlateral setae IV, three-fourths the length of $\mathrm{V}$, distinguish $A$. loxus from all other known members of this immediate group (i.e., species nos. 21, 22, $24)$.

Female. Chelicera with two subapical teeth plus pilus dentilis on fixed digit, one on movable digit. Dorsal shield $380 \mu$ long, $191 \mu$ wide, with four pairs of dorsocentral setae, center of proseutum sculptured, margins reticulate. Vertical setae $21 \mu$; dorsocentrals I-IV increasing from $28 \mu$ to $30 \mu$; clunals $13 \mu$; prolaterals I and II $30 \mu$, III $31 \mu$, IV $34 \mu$; postlaterals I $32 \mu$, II-IV $34 \mu, \mathrm{V} 42 \mu$; promediolaterals $28 \mu$, postmediolaterals $34 \mu$; sublaterals I $33 \mu$, II $34 \mu$; all setae smooth. Peritreme extending forward to base of vertical seta. Ventri-anal plate $102 \mu$ wide, $134 \mu$ long, with three pairs of preanal setae and with a pair of pores medially caudad to third pair of setae. Primary metapodal platelets $32 \mu$ long, $5 \mu$ wide; accessory platelets $14 \mu$ by $3 \mu$. Genital plate $71 \mu$ wide. Metasternal platelets distinct. Cervix of spermatheca $34 \mu$ long, atrium $6 \mu$. Leg IV with a short, relatively thick macroseta, $34 \mu$, on basitarsus.

Male. Unknown.

Holotype. Female, Nicks Cove, Tomales Bay, Marin County, September 14, 1960 (W. G. Iltis), from matted layers of $Z$ ostera marina on the sea- shore; type no. 2787 in the U. S. National Museum.

Paratypes. Three females, data same as for holotype.

\section{Amblyseius brevispinus (Kennett), new combination \\ (Fig. 43)}

Typhlodromus brevispinus Kennett, 1958, p. 473.

Typhlodromus (Amblyseius) brevispinus Kennett. Chant, $1960 a$, p. 78.

This species can be distinguished from Amblyseius loxus by the shorter, thinner dorsal setae and by the longer macroseta on basitarsus IV.

Female. Chelicera with two or three subapical teeth on fixed digit, one small tooth on movable digit. Dorsal shield $345 \mu$ long, $180 \mu$ wide, faintly reticulate along lateral margins; with four pairs of dorsocentral setae. Vertical setae $18 \mu$; dorsocentrals I and II $18 \mu$, III and IV $21 \mu$; clunals $13 \mu$; prolaterals I $15 \mu$, II $17 \mu$, III $23 \mu$, IV $27 \mu$; postlaterals I $24 \mu$, II $30 \mu$, III and IV $24 \mu, \mathrm{V} 48 \mu$; promediolaterals $25 \mu$, postmediolaterals $30 \mu$; sublaterals I and II $21 \mu$; all setae fine, simple. Peritreme extending forward to base of vertical seta. Ventri-anal plate $88 \mu$ wide, $115 \mu$ long, with three pairs of preanal setae and with a pair of small pores medially behind the third setae. Primary metapodal platelets $25 \mu$ long, $4 \mu$ wide; accessory platelets $8 \mu$ by $2 \mu$. Genital plate $87 \mu$ wide. Sternal plate with anterior margin weakly sclerotized, the first pair of setae often separate from the plate; metasternal platelets distinct. Cervix of spermatheca 25-30 $\mu$ long, thin, slightly expanded at base; atrium $8 \mu$ long. Leg IV with macroseta on basitarsus $50 \mu$.

Male. Unknown.

\section{COLLECTION DATA}

Alameda County: Berkeley, July 31, 1959 (B. E. Pullen). Contra Costa County: 10 miles east of Nortonville, October 15, 1952 (W. C. Bentinck). Napa County: Napa, December 2, 1958 (J. J. Skelsey). Orange County: 2 miles north of Laguna Beach, June 13, 

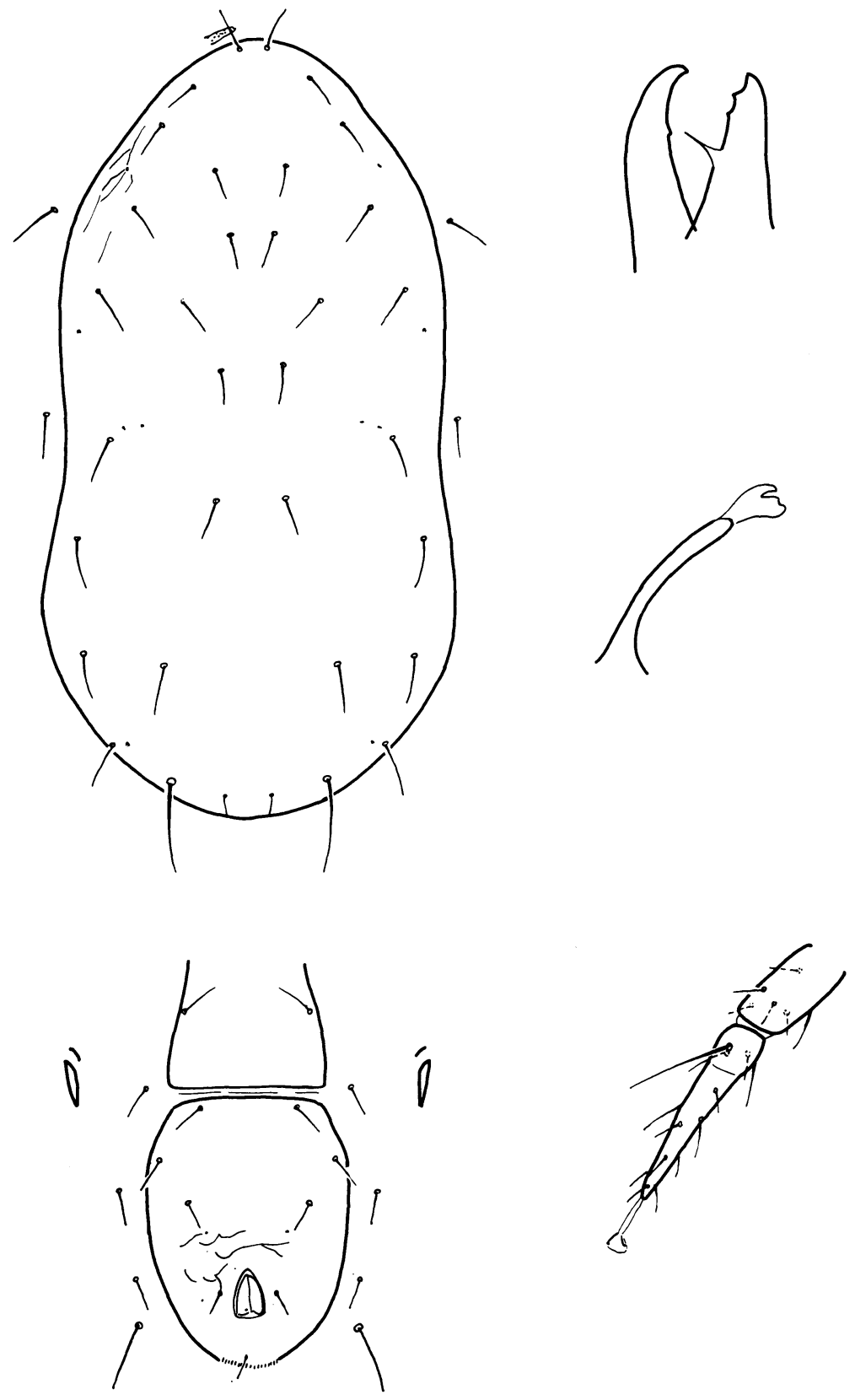

Fig. 43. Amblyseius brevispinus (Kennett).

1960 (H. L. McKenzie). Plumas County: Acampo, March 13, 1957 (R. County: 7 miles northwest of Chester, O. Schuster); Lodi, December 3, 1958; June 28 and August 10, and Warner Terminous, November 25, 1958 (A. A. Creek Campground, August 10, 1959 Grigarick); Victor, March 13, 1957 (R. (E. E. Lindquist). Sacramento O. Schuster, L. M. Smith). SaN Mateo County: Carmichael, February 19, County: Redwood City, August 5, 1959 1959 (R. F. Wilkey). SAN Joaquin (A. E. Pritchard). Santa Barbara 
County: Santa Maria, May 9, 1954 (C. E. Kennett). Santa Clara County: Coyote, October 6, 1953; Santa Clara, July and August, 1952 (W. W. Allen). Santa Cruz County: Soquel, July 17, 1952 (W. W. Allen); Watsonville, October 26, 1954, and August 19, 1957 (C. E. Kennett). Solano County: 5 miles southeast of Dixon, September 17, 1959 (C. L. Judson); 4 miles southwest of Fairfield, July 8, 1960 (R. O. Schuster). Sonoma County: 8 miles west of Santa Rosa, November 12, 1958 (W. H. Lange, H. L. McKenzie). Stanislaus County: Salida, September 10, 1959 (A. E. Pritchard). Tuolumne County: Tuolumne Meadows, June 20, 1957 (D. W. Price). Yolo County: 2 miles north of Davis, November 30, 1958 (R. O. Schuster); Knights Landing, September 27, 1960 (H. L. McKenzie).

Found in litter or on low-growing plants: Anemopsis californica, Cynodon dactylon, Distichlis, Fragaria hybrida, Pyracantha; Vitis bark; peat.

\section{Amblyseius kennetti, new species (Fig. 44)}

Probably the nearest relative of this species is Amblyseius callunae Willmann. We have not seen the type specimen of $A$. callunae, but $A$. kennetti differs at least in the absence of a macroseta on tibia IV.

Female. Chelicera with two subapical teeth on fixed digit before the pilus dentilis, movable digit apparently smooth. Dorsal shield $385 \mu$ long, $220 \mu$ wide, reticulate, with four pairs of dorsocentral setae. Vertical setae $21 \mu$, dorsocentrals about $14 \mu$, clunals $8 \mu$; prolaterals I $24 \mu$, II $21 \mu$, III $18 \mu$, IV $29 \mu$; postlaterals I $19 \mu$, II $23 \mu$, III $16 \mu$, IV $17 \mu$, V $67 \mu$; promediolaterals $14 \mu$, postmediolaterals $56 \mu$; sublaterals I $21 \mu$, II $19 \mu$; postmediolaterals and postlaterals $V$ with extremely faint serrations. Peritreme extending forward to base of prolateral seta I. Ventri-anal plate $120 \mu$ wide, $135 \mu$ long, with three pairs of preanal setae and with a pair of pores between and caudad to the third setae.
Venter with three pairs of ventrolateral setae. Primary metapodal platelets $30 \mu$ long, $5 \mu$ wide; accessory platelets $16 \mu$ by $3 \mu$. Genital plate $87 \mu$ wide. Sternal plate with three pairs of setae; metasternal platelets distinct. Cervix of spermatheca $15 \mu$ long, atrium about $5 \mu$. Leg IV with macroseta on basitarsus $51 \mu$, on genu $37 \mu$.

Male. Spermatodactyl longer than chelicera and at right angles to it. Ventri-anal plate with six pairs of preanal setae.

Holotype. Female, near Woods Lake, Alpine County, July 17, 1960 (C. Moore), from pine litter; type no. 2789 in the U. S. National Museum.

Paratypes. Eleven males, 17 females, data same as for holotype.

\section{ADDITIONAL RECORDS}

Alpine County: 3 and 5 miles north of Markleeville, May 11, 1959 (L. M. Smith). Amador County: Deadmans Flat, 23 miles east of Jackson, October 1, 1960 (A. Bray). El Dorado County: Echo Summit, elevation 7,000 feet, July 13, 1958 (F. C. Raney). Fresno County: Dinkey Creek, July 1, 1956 (E. L. Meyer). Lassen County: McCoy Flat Reservoir, September 28, 1958 (J. L. Campbell). Mariposa County: Yosemite Valley, January 19, 1958 (D. W. Price). Nevada County: 3.4 miles north of Truckee, June 20, 1960 (F. C. Raney). Plumas County: 8 miles northwest of Chester, August 15, 1960 (E. E. Lindquist) ; in and near Johnsville, June 28 and October 25, 1959 (J. S. Buckett). SaN Diego County: Spring Valley, May 10, 1958 (F. C. Raney). Shasta County: Ingot, February 3, 1959 (R. W. Gerhardt). SIERRA County: Bassett's Lodge, July 30, 1958 (A. A. Grigarick). Siskiyou County: Weed, July 19, 1959 (F. C. Raney). Tehama County: Post Pile Camp, at 5,800 feet, August 30, 1960 (A. A. Grigarick, R. O. Schuster). Tuolumne County: Leland Meadow, August 5, 1960 (D. Q. Cavagnaro). (Occurs also in Arizona, Colorado, Nevada, Oregon, 

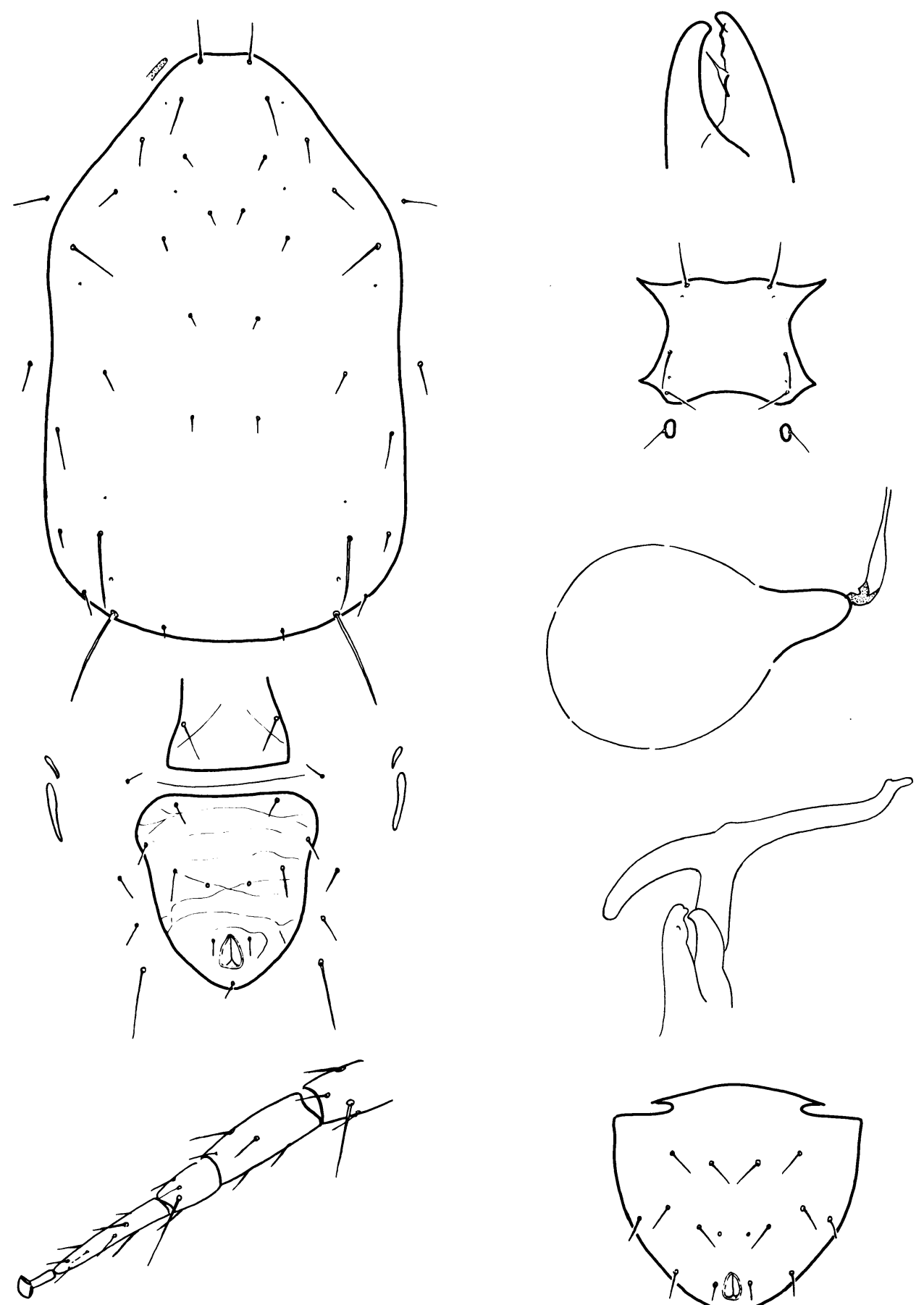

Fig. 44. Amblyseius kennetti, new species. 
and Washington; prevalent at high elevations.)

Found in litter of Abies concolor, $A$. grandis, A. nobilis, Aesculus, Alnus, Baccharis, Pinus contorta, P. fremontii, Pseudotsuga taxifolia, and Sequoia.

This species is named for Charles E. Kennett.
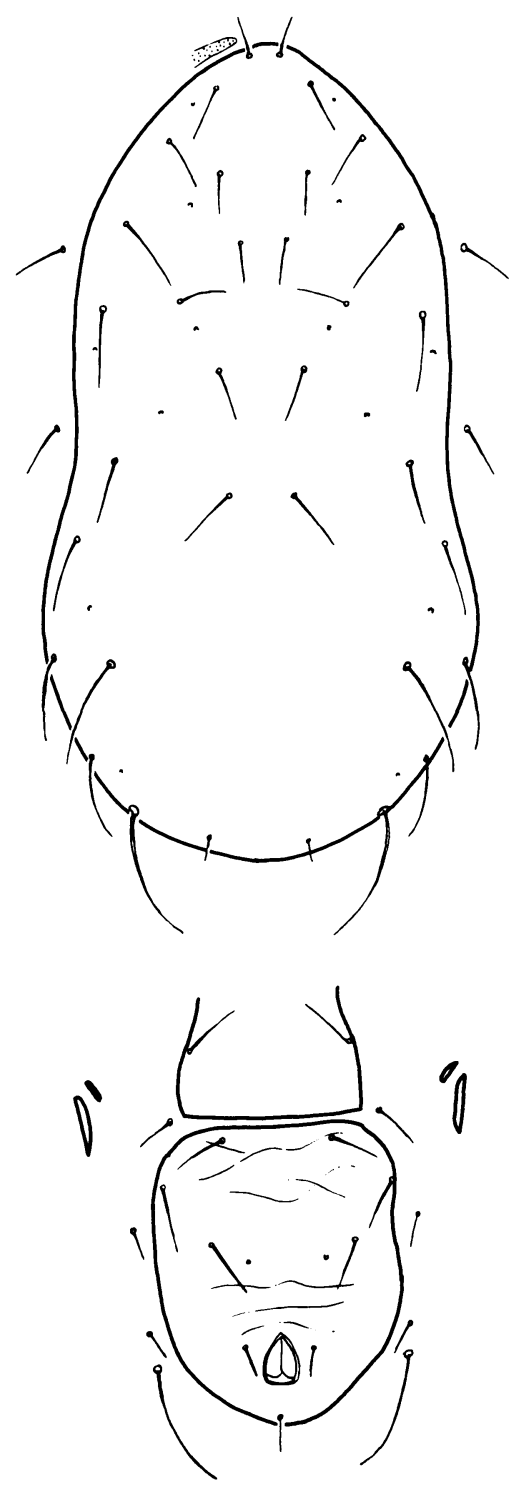

\section{Amblyseius vallis, new species}

(Fig. 45)

This species is related to both Amblyseius cucumeris and $A$. umbraticus (Chant). It differs from the former species by the shape of the spermatheca and from the latter (of which the sper-

Fig. 45. Amblyseius vallis, new species. 
matheca is undescribed) by having only one macroseta on leg IV.

Female. Chelicera with one, possibly two subapical teeth on fixed digit, movable digit apparently smooth. Dorsal shield $325 \mu$ long, $176 \mu$ wide, faintly reticulate along lateral margins; with four pairs of dorsocentral setae. Vertical setae $13 \mu$; dorsocentrals I $19 \mu$, II $16 \mu$, III $19 \mu$, IV $21 \mu$; clunals $9 \mu$; prolaterals I $25 \mu$, II and III $29 \mu$, IV $32 \mu$; postlaterals I $29 \mu$, II and III $39 \mu$, IV $40 \mu, \mathrm{V}$ $55 \mu$; promediolaterals $20 \mu$, postmediolaterals $50 \mu$; sublaterals I and II $24 \mu$; all setae smooth. Peritreme extending forward to base of vertical seta. Ventrianal plate $94 \mu$ wide, $118 \mu$ long, with three pairs of preanal setae and with a pair of pores behind and mediad to third setae. Primary metapodal platelets $27 \mu$ long, $5 \mu$ wide; accessory platelets $8 \mu$ by $2 \mu$. Genital plate $64 \mu$ wide. Sternal plate with three pairs of setae; metasternal platelets small. Cervix and atrium of spermatheca each $12 \mu$. Leg IV with macroseta on basitarsus $42 \mu$.

Male. Unknown.

Holotype. Female, Mix Canyon, SoLano County, August 17, 1960 (A. Bray, J. L. Campbell), from litter under Aesculus californica; type no. 2790 in the U. S. National Museum.

\section{Amblyseius zwoelferi (Dosse), new combination (Fig. 46)}

Typhlodromus zwölferi Dosse, 1957, p. 301. Typhlodromus (Amblyseius) zwoelferi Dosse. Chant, 1960a, p. 78.

Usually the California specimens of Amblyseius zwoelferi can be distinguished from European by the postmediolateral setae, which extend past the pores associated with postlateral setae IV, and by the presence of a short macroseta on the genu of leg IV. However, the California populations are variable, and occasional specimens closely resemble those from Europe.

Female. Chelicera with three teeth between apex and pilus dentilis of fixed digit, movable digit apparently smooth.
Dorsal shield $400 \mu$ long, $230 \mu$ wide, reticulate, with four pairs of dorsocentral setae. Vertical setae $21 \mu$; dorsocentrals I $25 \mu$, II and III about $16 \mu$, IV $21 \mu$; clunals $10 \mu$; prolaterals I $25 \mu$, II $21 \mu$, III $31 \mu$, IV $30 \mu$; postlaterals I $24 \mu$, II $28 \mu$, III $30 \mu$, IV $27 \mu$, V $60 \mu$; promediolaterals $16 \mu$, postmediolaterals $42 \mu$; sublaterals I and II $25 \mu$; all setae simple except postlaterals $\mathrm{V}$, which are faintly serrate. Peritreme extending forward to base of vertical seta. Ventri-anal plate $112 \mu$ wide, $148 \mu$ long, with three pairs of preanal setae and with a pair of pores caudad and slightly mediad to third setae. Venter with three pairs of ventrolateral setae. Primary metapodal platelets $34 \mu$ long, accessory platelets about $17 \mu$ long. Cervix and atrium of spermatheca, combined lengths, about $30 \mu$. Leg IV with macroseta on basitarsus $60 \mu$, and usually with a distinct macroseta on genu.

Male. Not collected in California.

\section{COLLECTION DATA}

Marin County: Stinson Beach, June 24, 1958 (C. D. Brickhill). Plumas County: Johnsville, June 28, 1959 (J. S. Buckett). Solano County: 4 miles southwest of Fairfield, July 8, 1960 (R. O. Schuster); north side of Montezuma Slough near Grizzly Island, October 14, 1959 (C. L. Judson) and October 20, 1959 (R. O. Schuster).

Found in litter of grass, Pinus contorta, and Populus fremontii; mixed foliage of Distichlis spicata, Mesembryanthemum, and Salicornia ambigua.

\section{Amblyseius mckenziei, new species} (Fig. 47)

Amblyseius mckenziei is closely related to $A$. huffakeri but has longer dorsal setae, especially postlateral setae $V$, and a closer spacing of the preanal pores. In both species the spermatheca has a slender, tapered cervix and large, bifid atrium. In $A$. huffakeri the cervix is bent.

Female. Chelicera with two distinct subapical teeth on fixed digit, one on 

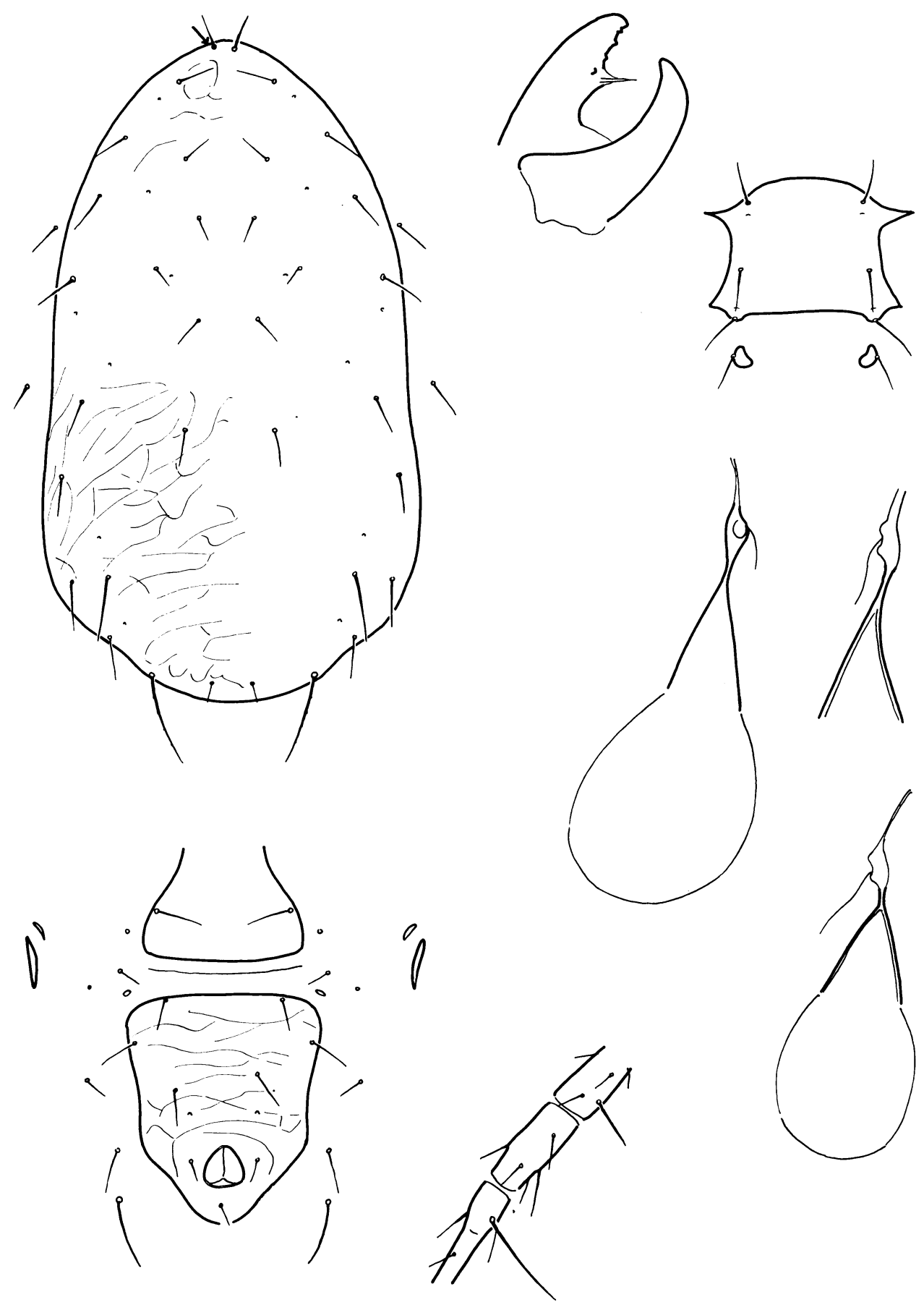

i

Fig. 46. Amblyseius zwoelferi (Dosse). 

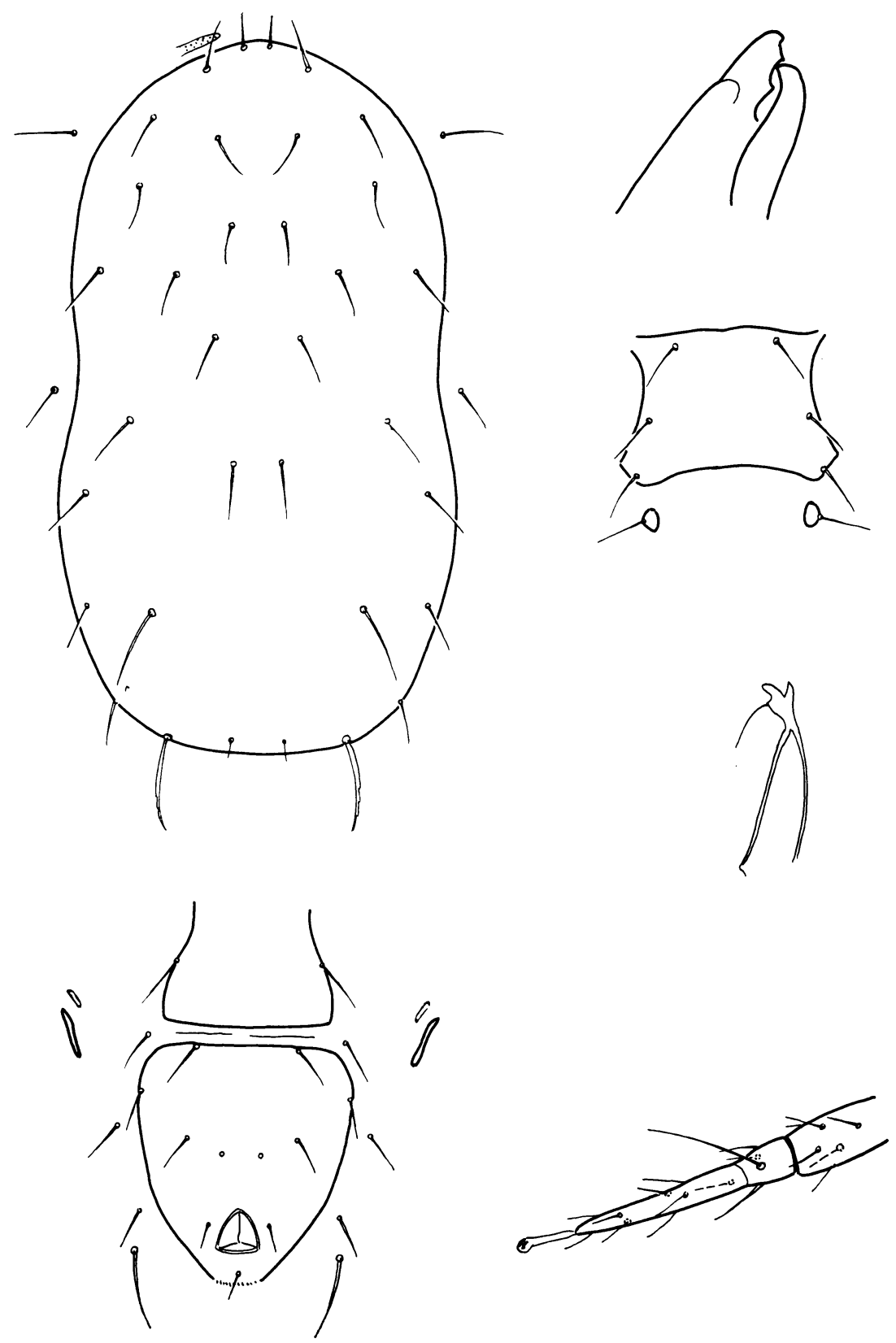

Fig. 47. Amblyseius mckenziei, new species.

movable digit. Dorsal shield $345 \mu$ long, $190 \mu$ wide, smooth, with four pairs of dorsocentral setae. Vertical setae $18 \mu$; dorsocentrals I-III $17 \mu$, IV $21 \mu$; clunals $17 \mu$; prolaterals I $30 \mu$, II $18 \mu$, III and IV $23 \mu$; postlaterals I $25 \mu$, II $26 \mu$, III and IV $25 \mu, \mathrm{V} 51 \mu$; promediolaterals
$21 \mu$, postmediolaterals $38 \mu$, sublaterals I $25 \mu$, II $23 \mu$. Peritreme extending forward to base of vertical seta. Ventrianal plate $107 \mu$ wide, $125 \mu$ long, with three pairs of preanal setae and with a pair of pores between and caudad to the third setae. Three pairs of ventro- 
lateral setae. Primary metapodal platelets $29 \mu$ long, $5 \mu$ wide; accessory platelets $13 \mu$ by $3 \mu$. Genital plate $77 \mu$ wide. Third pair of sternal setae on sternal plate. Metasternal platelets distinct. Cervix of spermatheca $23 \mu$ long, atrium $5 \mu$. Leg IV with macroseta on basitarsus $63 \mu$.

Male. Unknown.

Holotype. Female, 11/2 miles north of Cajon Pass, San Bernardino County, June 12, 1960 (H. L. McKenzie), under juniper; type no. 2791 in the U. S. National Museum.

Paratype. One female, Walker Pass, Kern County, May 12, 1959 (L. M. Smith).

One female from Redwood City, SAN Mateo County, August 5, 1959 (A. E. Pritchard), from bermudagrass, also appears to represent this species.

Amblyseius mckenziei is named for Howard L. McKenzie.

\section{Amblyseius buffakeri, new species} (Fig. 48)

Amblyseius huffakeri is closely related to $A$. mckenziei, but has shorter dorsal setae and wider spacing of the preanal pores, and its spermathecal cervix is bent.

Female. Chelicera with three subapical teeth on fixed digit, one on movable digit. Dorsal shield $360 \mu$ long, $180 \mu$ wide, lightly reticulate along margin of proscutum, with four pairs of dorsocentral setae. Vertical, dorsocentral, prolateral (four pairs), promediolateral (one pair), and sublateral setae all between $17 \mu$ and $19 \mu$; clunals $12 \mu$; postlaterals I $19 \mu$, II and III $21 \mu$, IV $19 \mu$, $\mathrm{V} 34 \mu$; postmediolaterals $30 \mu$. Peritreme extending forward to base of vertical seta. Ventri-anal plate $95 \mu$ wide, $105 \mu$ long, with three pairs of preanal setae and with a pair of pores medially behind the third setae. Three pairs of ventrolateral setae. Primary metapodal platelets $20 \mu$ long, $5 \mu$ wide; accessory platelets $8 \mu$ by $3 \mu$. Genital plate $76 \mu$ wide. Sternal plate with three pairs of setae; metasternal plate- lets distinct. Cervix of spermatheca $21 \mu$ long, slender, tapering, and bent; large, bifid atrium $8 \mu$. Leg IV with macroseta on basitarsus $42 \mu$.

Male. Ventri-anal plate with three pairs of preanal setae and a pair of pores.

Holotype. Female, Post Pile Camp, Tehama County, at 5,800 feet, August 30, 1960 (A. A. Grigarick, R. O. Schuster); type no. 2792 in the U. S. National Museum.

Paratypes. Three males, data same as for holotype; one female, Carmichael, Sacramento County, February 19, 1959 (R. F. Wilkey), from Pyracantha litter; one female, 7 miles northwest of Chester, Plumas County, June 28, 1959 (E. E. Lindquist), from sod; and two females, 5 miles north of Lake Britton, Shasta County, June 14, 1960 (W. Wiard, C. Wade).

This species is named for Carl B. Huffaker.

\section{Amblyseius californicus (McGregor), new combination}

(Fig. 49)

Typhlodromus californicus McGregor, 1954, p. 89.

Typhlodromus mungeri McGregor, 1954, p. 92. Amblyseius mungeri (McGregor). AthiasHenriot, 1959, p. 145.

Typhlodromus (Amblyseius) marinus (Willmann). Chant, $1960 a$, p. 79.

We are retaining McGregor's name for the California population. Chant (1960a) used the similarity of the males to synonymize Amblyseius californicus (=mungeri) with A. marinus Willmann, although he stated that the females differed in the shape of the coxal glands (spermathecae). The females of the California population bear no close resemblance to Chant's illustration of the female of $A$. marinus. Moreover, the male ventri-anal plate which Chant illustrated lacks the crescentic pores that are conspicuous in both sexes in our collection.

Female. Chelicera with two subapical teeth on fixed digit, one on movable digit. Dorsal shield $355 \mu$ long, 

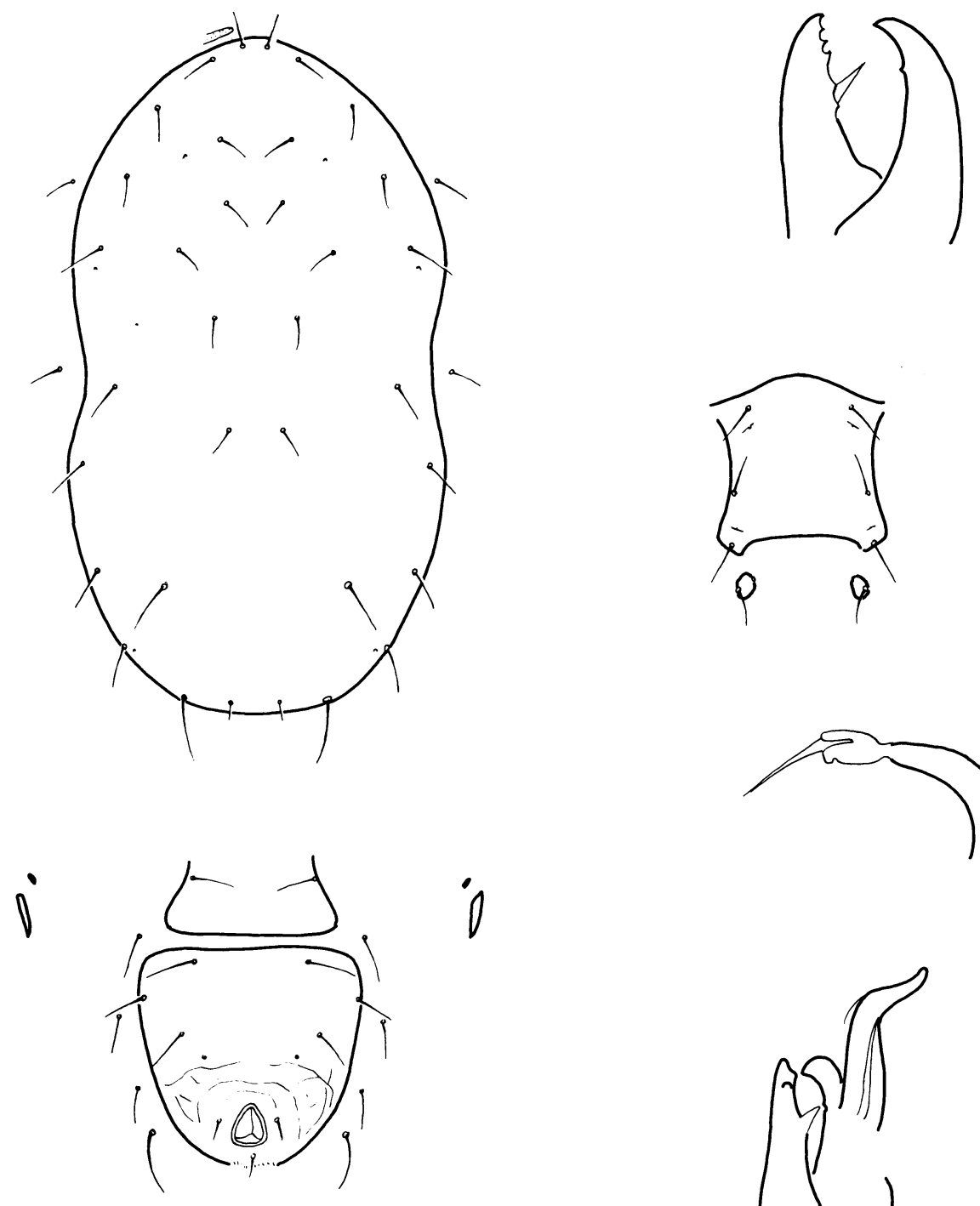

i
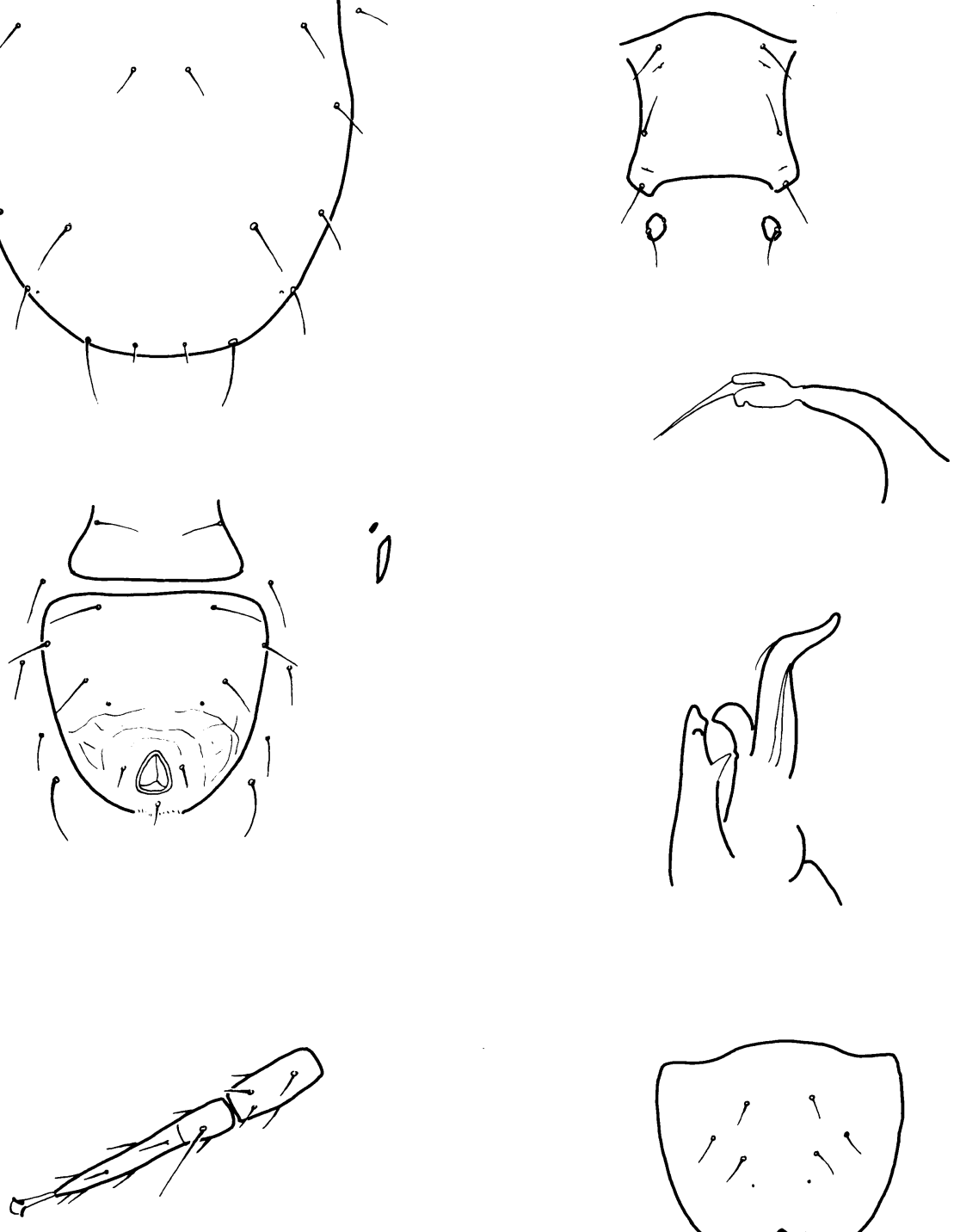

Fig. 48. Amblyseius huffakeri, new species.

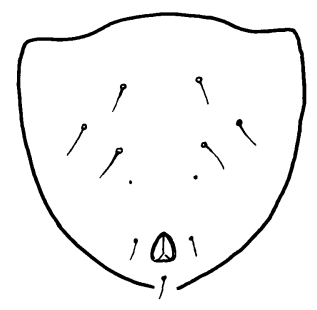



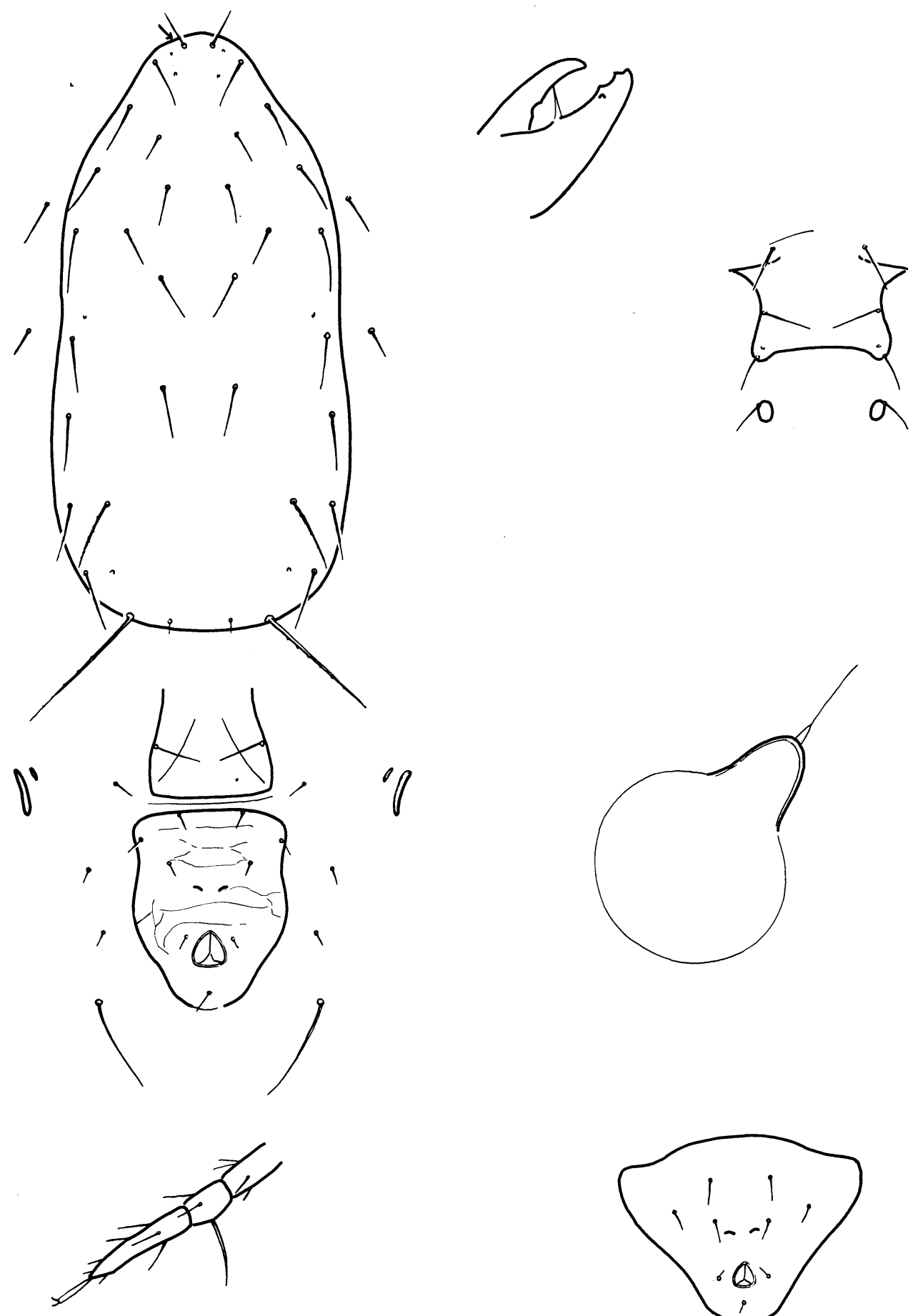

Fig. 49. Amblyseius californicus (McGregor). 
$170 \mu$ wide, faintly reticulate, with four pairs of dorsocentral setae. Vertical setae $20 \mu$; dorsocentrals I $25 \mu$, II $22 \mu$, III $28 \mu$, IV $30 \mu$; clunals $14 \mu$; prolaterals I $34 \mu$, II $30 \mu$, III and IV $36 \mu$; postlaterals I $36 \mu$, II $39 \mu$, III $35 \mu$, IV $34 \mu$, $\mathrm{V} 76 \mu$; promediolaterals $24 \mu$, postmediolaterals $51 \mu$; sublaterals I $25 \mu$, II $22 \mu$; postmediolaterals and postlaterals $\mathrm{V}$ distinctly serrate. Peritreme extending forward to base of vertical seta. Ventri-anal plate $98 \mu$ wide, $115 \mu$ long, with three pairs of preanal setae and with a pair of crescentic pores medially caudad to third setae. Three pairs of ventrolateral setae. Primary metapodal platelets $25 \mu$ long, $6 \mu$ wide; accessory platelets of irregular shape, $6 \mu$ in greatest dimension. Genital plate $72 \mu$ wide. Sternal plate with three pairs of setae; metasternal platelets small but distinct. Cervix of spermatheca $11 \mu$ long, cup-shaped. Leg IV with macroseta on basitarsus $48 \mu$ long.

Male. Ventri-anal plate with three, sometimes four, pairs of preanal setae and a pair of crescentic pores.

\section{COLLECTION DATA}

Riverside County: Riverside, November 30, 1958 (C. L. Judson). SAN Diego County: San Diego, 1958.

Found on citrus and in pecan litter.

\section{Amblyseius scyphus, new species} (Fig. 50)

This species resembles Amblyseius californicus, with the following exceptions: (1) It is a larger species, more than $420 \mu$ in length. (2) The chelicera is multidentate, usually with four distinct teeth between pilus dentilis and apex. (3) The serration of the postmediolateral setae and of postlateral setae V is weaker. (4) The preanal pores are more nearly behind the third pair of preanal setae. (5) The cervix of spermatheca is wider than its length. (6) The macroseta on the fourth leg is longer and more conspicuous.

Female. Chelicera with four subapical teeth on fixed digit, one on mova- ble digit. Dorsal shield $427 \mu$ long, $220 \mu$ wide, faintly reticulate, with four pairs of dorsocentral setae. Vertical setae $28 \mu$; dorsocentrals I $14 \mu$, II $17 \mu$, III $19 \mu$, IV $20 \mu$; clunals $13 \mu$; prolaterals I $33 \mu$, II $24 \mu$, III $22 \mu$, IV $34 \mu$; postlaterals I $21 \mu$, II $32 \mu$, III $34 \mu$, IV $40 \mu$, $\mathrm{V} 80 \mu$; promediolaterals $15 \mu$, postmediolaterals $40 \mu$; sublaterals I and II $29 \mu$; postlaterals III-V and postmediolaterals faintly serrate. Peritreme extending forward approximately to base of prolateral seta I. Ventri-anal plate $110 \mu$ wide, $150 \mu$ long, with three pairs of preanal setae and with a pair of small pores almost directly behind third pair of setae. Venter with three pairs of ventrolateral setae. Primary metapodal platelets $39 \mu$ long, $6 \mu$ wide; accessory platelets $14 \mu$ by $3 \mu$. Genital plate $85 \mu$ wide. Sternal plate with three pairs of setae and two pairs of pores. Metasternal platelets small. Cervix of spermatheca cup-shaped, $9 \mu$ long, atrium between 3 and $4 \mu$. Leg IV with macroseta on basitarsus $70 \mu$.

Male. Ventri-anal plate with two or three pairs of preanal setae and a pair of small pores.

Holotype. Female, Salida, Stanislaus County, November 10, 1959 (A. E. Pritchard), on bermudagrass; type no. 2793 in the U. S. National Museum.

Paratypes. Seventy-five specimens on seven slides; data same as for holotype.

\section{ADDITIONAL RECORDS}

Contra Costa County: 5 miles east of Clayton, October 8, 1952 (J. W. MacSwain). Fresno County: Huron, September 20, 1953 (A. E. Pritchard). Glenn County: 4 miles east of Artois, June 27,1952(W. C. Bentinck). StanisLaus County: Salida, September 10, 1959 (A. E. Pritchard). Yolo County: Davis, November 5, 1956 (J. K. AbulHab). Albuquerque, New Mexico, July 8, 1959 (B. E. Pullen). Geneva, New YoRk, July 29, 1949 (S. Lienk).

Found on several grasses, including bermudagrass and salt-marsh grass; morning-glory, rotting onion. 


\section{Amblyseius tabis, new species}

(Fig. 51)

Amblyseius tabis is closely allied to A. cucumeris, from which it differs most obviously by its shorter postlateral setae

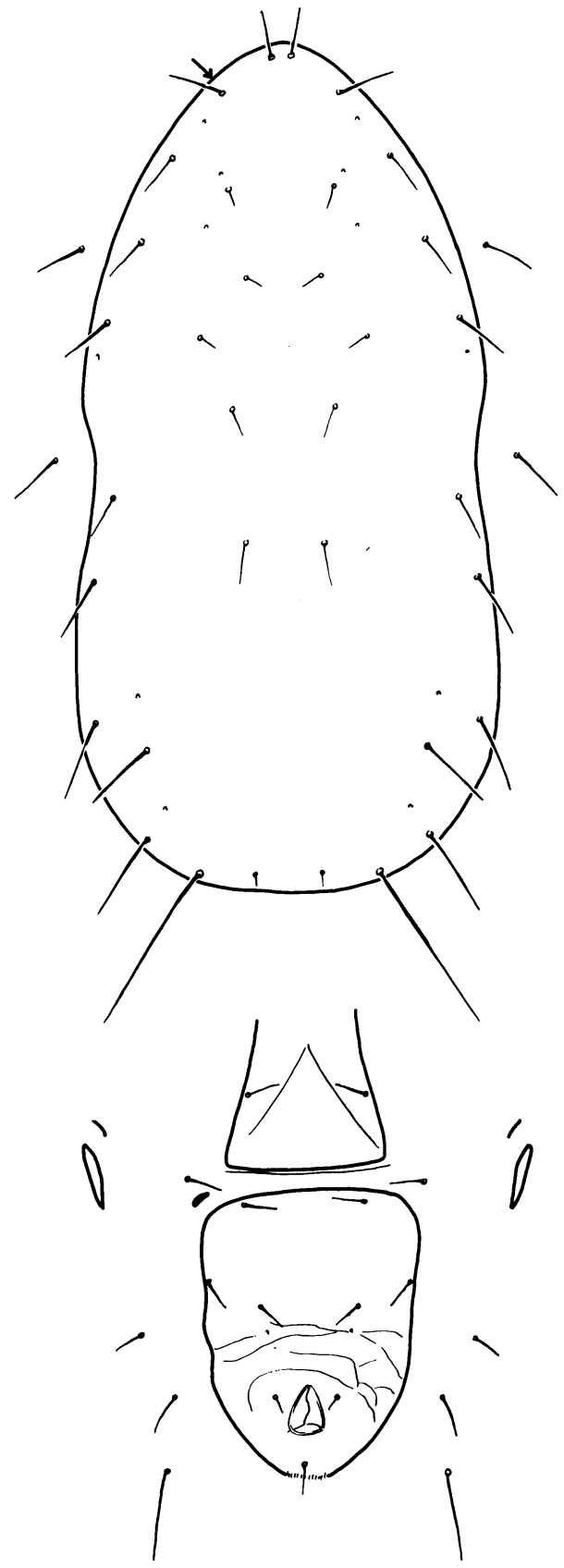

and by the tapering cervix of the spermatheca.

Female. Chelicera with two subapical teeth on fixed digit, movable digit apparently smooth. Dorsal shield $420 \mu$ long, $235 \mu$ wide, reticulate, with
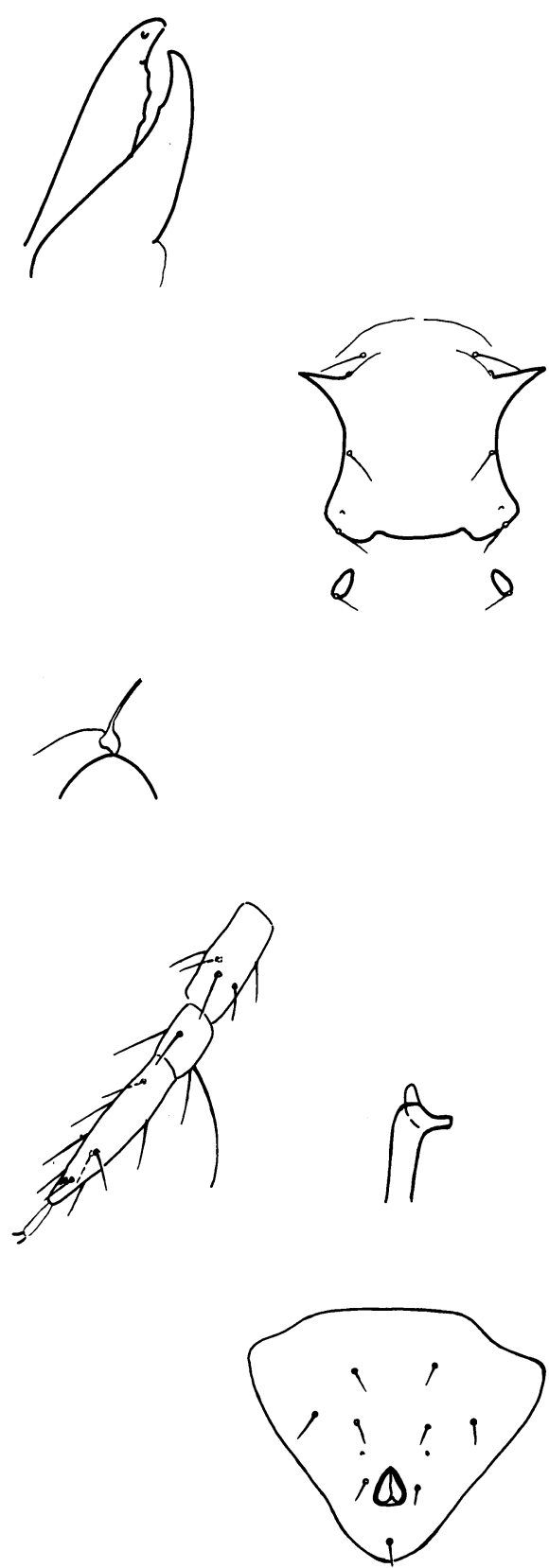

Fig. 50. Amblyseius scyphus, new species. 

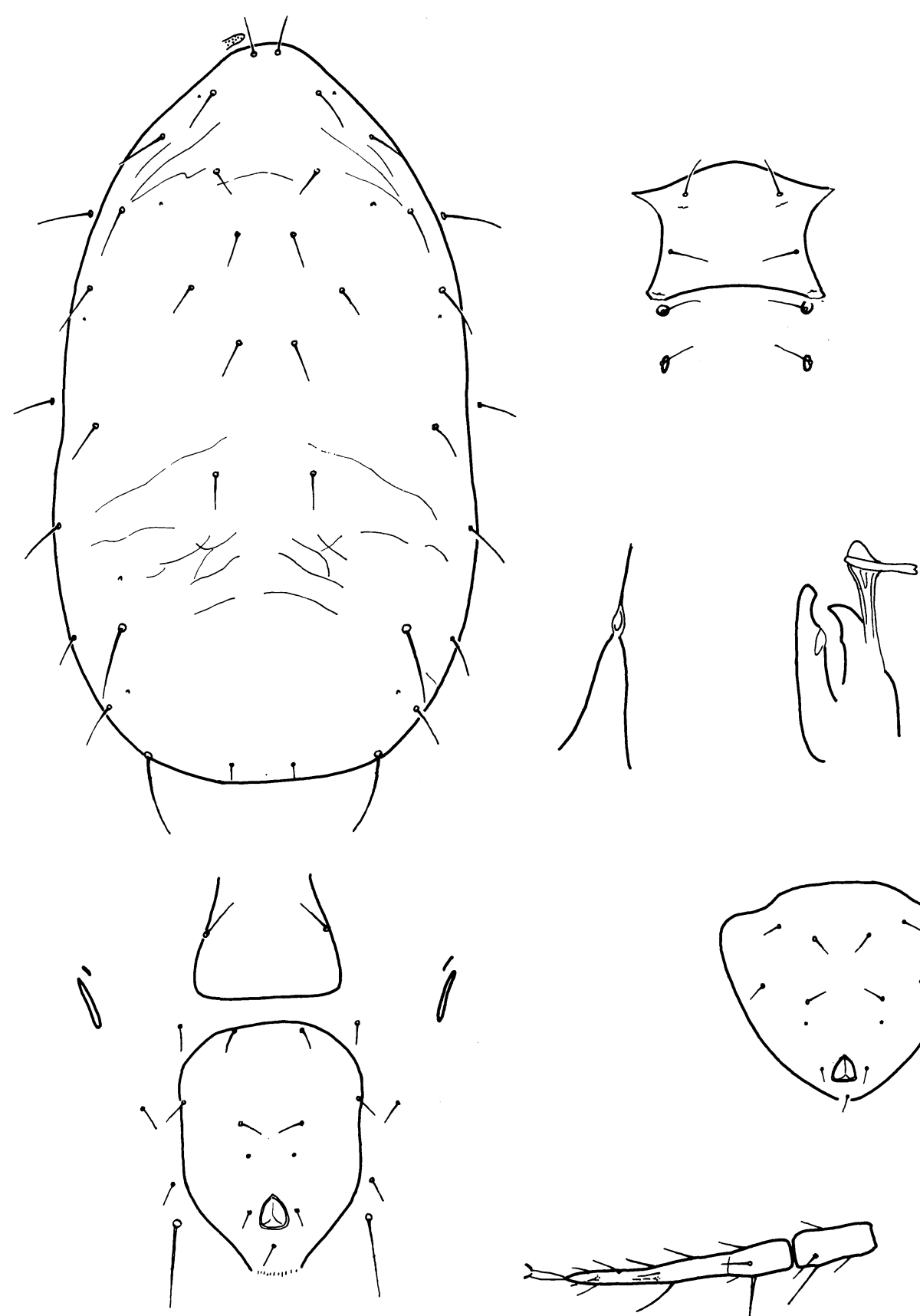

1

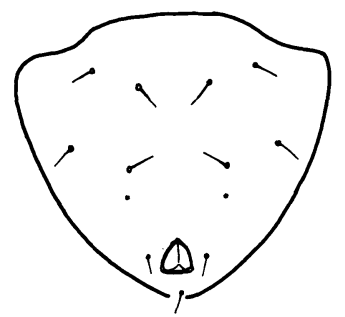

Fig. 51. Amblyseius tabis, new species.

four pairs of dorsocentral setae. Vertical setae $23 \mu$; dorsocentrals I-III about $17 \mu$, IV $23 \mu$; clunals $14 \mu$; prolaterals I $25 \mu$, II and III $28 \mu$, IV $34 \mu$; postlaterals I $29 \mu$, II $32 \mu$, III $25 \mu$, IV
$22 \mu, \mathrm{V} 53 \mu$; promediolaterals $17 \mu$, postmediolaterals $45 \mu$; sublaterals I and II about $26 \mu$; postlaterals V serrate. Peritreme extending forward to near base of vertical seta. Ventri-anal plate 
$101 \mu$ wide, $148 \mu$ long, with three pairs of preanal setae and with a pair of pores behind third pair of setae. Three pairs of ventrolateral setae. Primary metapodal platelets $30 \mu$ long, $6 \mu$ wide ; accessory platelets $8 \mu$ by $2 \mu$. Genital plate $81 \mu$ wide. Third pair of sternal setae separate from plate; metasternal platelets small but distinct. Cervix of spermatheca $21 \mu$ long, atrium $3 \mu$. Leg IV with macroseta on basitarsus $46 \mu$, on tibia $25 \mu$, on genu $33 \mu$.

Male. Ventri-anal plate with four pairs of preanal setae and one pair of pores.

Holotype. Female from Encinitas, SAN Diego Countr, June 13, 1960, from bermudagrass association near beach (H. L. McKenzie) ; type no. 2794 in the U. S. National Museum.

Paratypes. Thirty-two females and nine males, with data same as for the holotype.

\section{ADDITIONAL RECORDS}

Specimens from additional localities are considered conspecific but are not included in the paratypic series. LASSEN County: McCoy Flat Reservoir, September 28, 1958 (J. L. Campbell). Marin County: June 26, 1958 (C. D. Brickhill). Napa County: Napa, October 28, 1958, and June 15, 1959 (J. J. Skelsey) and February 3, 1959 (R. O. Schuster). SaN Mateo County: shore of San Andreas Lake, November, 1957, and San Bruno Mountains, January, 1958 (D. W. Price). Base of Mt. Scott, Oregon, August 1, 1959 (F. C. Raney).

Taken from bermudagrass association near beach, French prune, grassland, litter, Pinus contorta litter, soil.

\section{Amblyseius cucumeris (Oudemans)} (Fig. 52)

Typhlodromus cucumeris Oudemans, 1930, p. 69.

Typhlodromus thripsi MacGill, 1939, p. 309.

Typhlodromus thripsi MacGill. Evans, 1952b, p. 416.

Typhlodromus bellinus Womersley, 1954, p. 177.

Typhlodromus bellinus Womersley. Dosse, 1957, p. 307.
Amblyseius cucumeris (Oudemans). AthiasHenriot, 1957, p. 336.

Typhlodromus (Typhlodromopsis) cucumeris Oudemans. De Leon, 1959c, p. 113.

Typhlodromus (Amblyseius) cucumeris Oudemans. Chant, $1960 a$, p. 78 .

We agree with Dosse that the California population is the cosmopolitan species Amblyseius cucumeris. Kennett (1958) identified it as Typhlodromus bellinus, but Dosse had already synonymized these two species.

Female. Chelicera with three subapical teeth on fixed digit, one on movable digit. Dorsal shield $395 \mu$ long, $210 \mu$ wide, lightly but generally reticulate, with four pairs of dorsocentral setae. Vertical setae $27 \mu$; dorsocentrals I $21 \mu$, II $17 \mu$, III $21 \mu$, IV $25 \mu$; clunals $13 \mu$; prolaterals I $35 \mu$, II and III $32 \mu$, IV $40 \mu$; postlaterals I $30 \mu$, II $40 \mu$, III $39 \mu$, IV $34 \mu$, V $70 \mu$; promediolaterals $20 \mu$, postmediolaterals $40 \mu$; sublaterals I $30 \mu$, II $28 \mu$; postlaterals V faintly serrate. Peritreme extending forward nearly to base of vertical seta. Ventrianal plate $114 \mu$ wide, $143 \mu$ long, with three pairs of preanal setae and with a pair of pores mediad and slightly caudad to third setae; anterolateral margins of ventri-anal plate tending to be reduced. Three pairs of ventrolateral setae. Primary metapodal platelets $25 \mu$ long, $7 \mu$ wide ; accessory platelets $13 \mu$ by $3 \mu$. Genital shield $76 \mu$ wide. Sternal plate with three pairs of setae and two pairs of pores; metasternal platelets distinct. Cervix of spermatheca $20 \mu$ long, with a small erescentic atrium at its apex. Leg IV with macroseta on basitarsus $60 \mu$, on tibia $36 \mu$, on genu $30 \mu$.

Male. Ventri-anal plate with three or four pairs of preanal setae and one pair of pores.

\section{COLLECTION DATA}

Alameda County : Albany, May, 1952 (C. E. Kennett), in greenhouse; Berkeley, June 27, 1952 (W. W.Allen), in greenhouse. Monterey County: 7 miles northwest of Castroville, August 

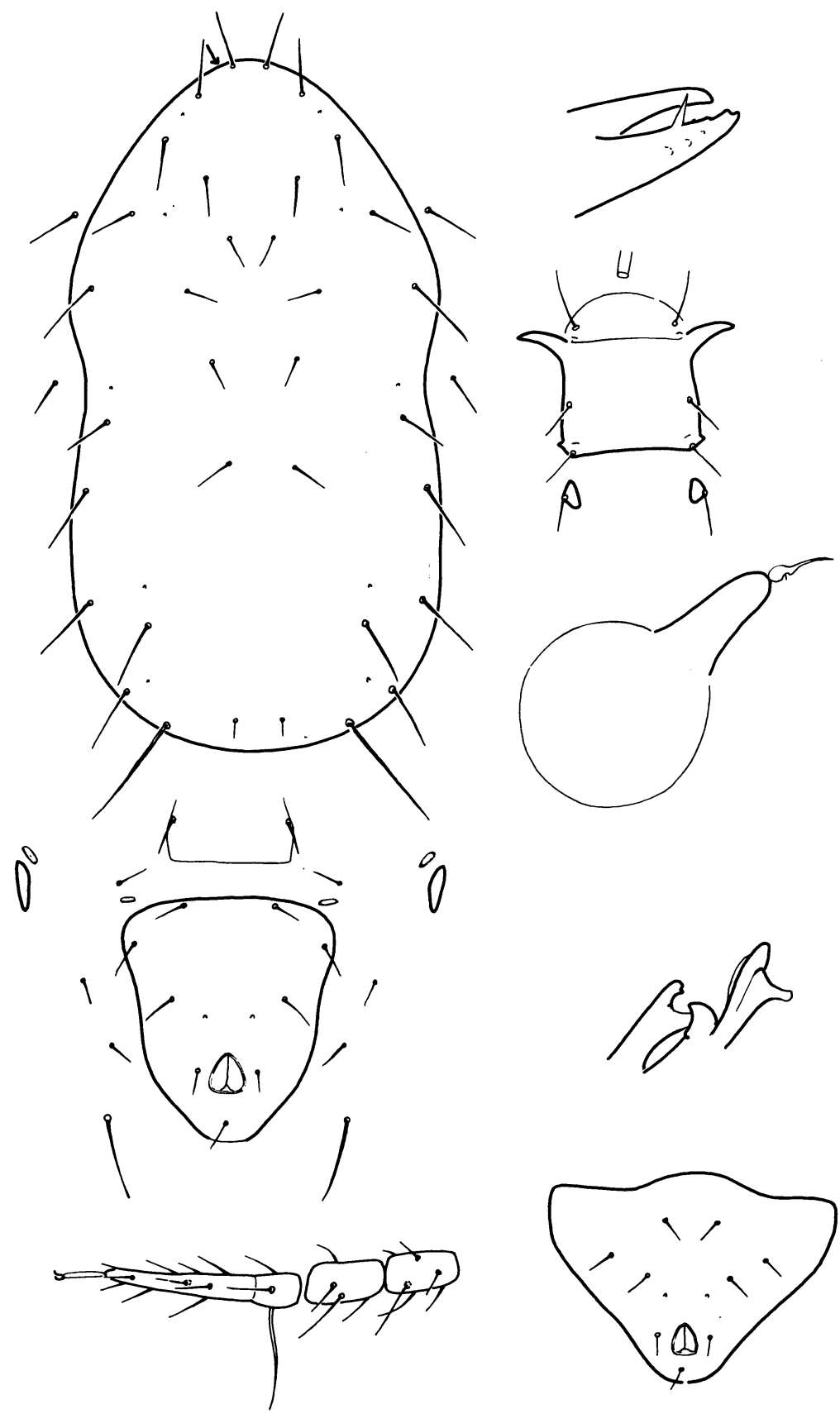

Fig. 52. Amblyseius cucumeris (Oudemans).

15, 1959 (E. E. Lindquist). NAPA County: 7 miles west of Oakville, January 3, 1958 (R. O. Schuster). SAN Joaquin County: Terminous (A. A. Grigarick). SANTA Barbara County:
Santa Maria, May, 1954 (C. E. Kennett). Santa Clara County: Berryessa, August 13, 1952 (W. W. Allen); Campbell, September 21, 1954 (W. W. Allen); 7 miles west of San Jose, 
March 17, 1952; San Martin, February, 1954 (C. E. Kennett); Santa Clara, June 13 and August 25, 1952 (W. W. Allen). Santa Cruz County: Soquel, March 23, 1953 (W. W. Allen); Watsonville, August 10, 1953. StanisLaus County: Salida, May 25, 1956. Yolo County: Davis, January 6, 1958, in cultures, and February and March, 1959, in greenhouse (R. O. Schuster). Dunedin, New Zealand, June 4, 1948 (D. Spiller).

Found on Cynodon, Eucalyptus, Fragaria, Vitis; peat. Prey includes Steneotarsonemus pallidus.

\section{Genus Phytoseiulus Evans}

Phytoseiulus Evans, 1952a, p. 397.

\section{Pbytoseiulus macropilis (Banks)}

(Fig. 53)

Laelaps macropilis Banks, 1905, p. 139.

Hypoaspis macropilis (Banks). Banks, 1915, p. 85.

Phytoseiulus speyeri Evans, $1952 a$, p. 397.

Phytoseiulus macropilis (Banks). Cunliffe and Baker, 1953, p. 23.

Phytoseiulus speyeri Evans. Chant, 1960a, p. 109.

The single pair of preanal setae on the female distinguishes this species from others in the genus.

Female. Chelicera with seven or eight teeth on fixed digit, two on movable digit. Dorsal shield $340 \mu$ long, $225 \mu$ wide, reticulate along margins; with three pairs of dorsocentral setae. Vertical setae $27 \mu$; dorsocentrals I $60 \mu$, II $75 \mu$, III $110 \mu$; clunals $6-8 \mu$; prolaterals I $35 \mu$, II $14 \mu$, III $67 \mu$, IV $145 \mu$; postlaterals I $110 \mu$, II $40 \mu$, III $105 \mu$; promediolaterals $10 \mu$, postmediolaterals $125 \mu$; sublaterals I and II $21 \mu$; the larger setae faintly serrate. Peritreme extending forward to or beyond prolateral seta II. Ventri-anal plate $77 \mu$ wide, $94 \mu$ long, with one pair of preanal setae. Three pairs of setae on ventral membrane, not homologs of the usual ventrolateral setae, but located more anteriorly. Primary metapodal platelets $31 \mu$ long, $6 \mu$ wide; accessory platelets $17 \mu$ by $4 \mu$. Genital plate $90 \mu$ wide. Metasternal platelets large. Cervix of spermatheca $40 \mu$ long, atrium $5 \mu$. Leg IV with macroseta on basitarsus $87 \mu$, on genu $75 \mu$.

Male. Dorsal shield 260 $\mu$ long, $200 \mu$ wide. Ventri-anal plate with three or four pairs of preanal setae.

\section{COLLECTION DATA}

Santa Cruz County: Soquel, March 23, 1953, Watsonville, June 15, 1948, and March 26, 1953 (W. W. Allen).

Found on strawberry. This mite has been found feeding on the two-spotted spider mite.

\section{TRIBE PHYTOSEIINI BERLESE}

Phytoseiini Berlese, 1916, p. 33.

$$
\text { KEY TO GENERA OF THE WORLD: FEMALES }
$$

1. Sublateral setae II present; scutum smooth ................. Pennaseius (p. 279) Sublateral setae II absent; scutum rugose $\ldots \ldots \ldots \ldots \ldots \ldots \ldots \ldots \ldots \ldots$. . . . . . . . . .

\section{Genus Pennaseius Pritchard and Baker}

Phytoseius (Pennaseius) Pritchard and Baker, 1962, p. 223.

\section{Pennaseius finitimus (Ribaga), new combination}

(Fig. 54)

Phytoseius finitimus Ribaga, 1902, p. 178.

Phytoseius (Pennaseius) finitimus Ribaga. Pritchard and Baker, 1962, p. 224.

Female: Dorsal shield $295 \mu$ long, $170 \mu$ wide. Vertical setae $25 \mu$; dorso- centrals I-III $13 \mu$, IV $17 \mu$; clunals $8 \mu$; prolaterals I $51 \mu$, II $15 \mu$, III $34 \mu$, IV $15 \mu, \mathrm{V} 80 \mu$, VI $86 \mu$; postlaterals (single pair) $90 \mu$; promediolaterals $10 \mu$, postmediolaterals $63 \mu$; sublaterals I (on scutum) $50 \mu$, II (on membrane) $23 \mu$; all macrosetae serrate. Peritreme extending to base of prolateral II. Ventri- 


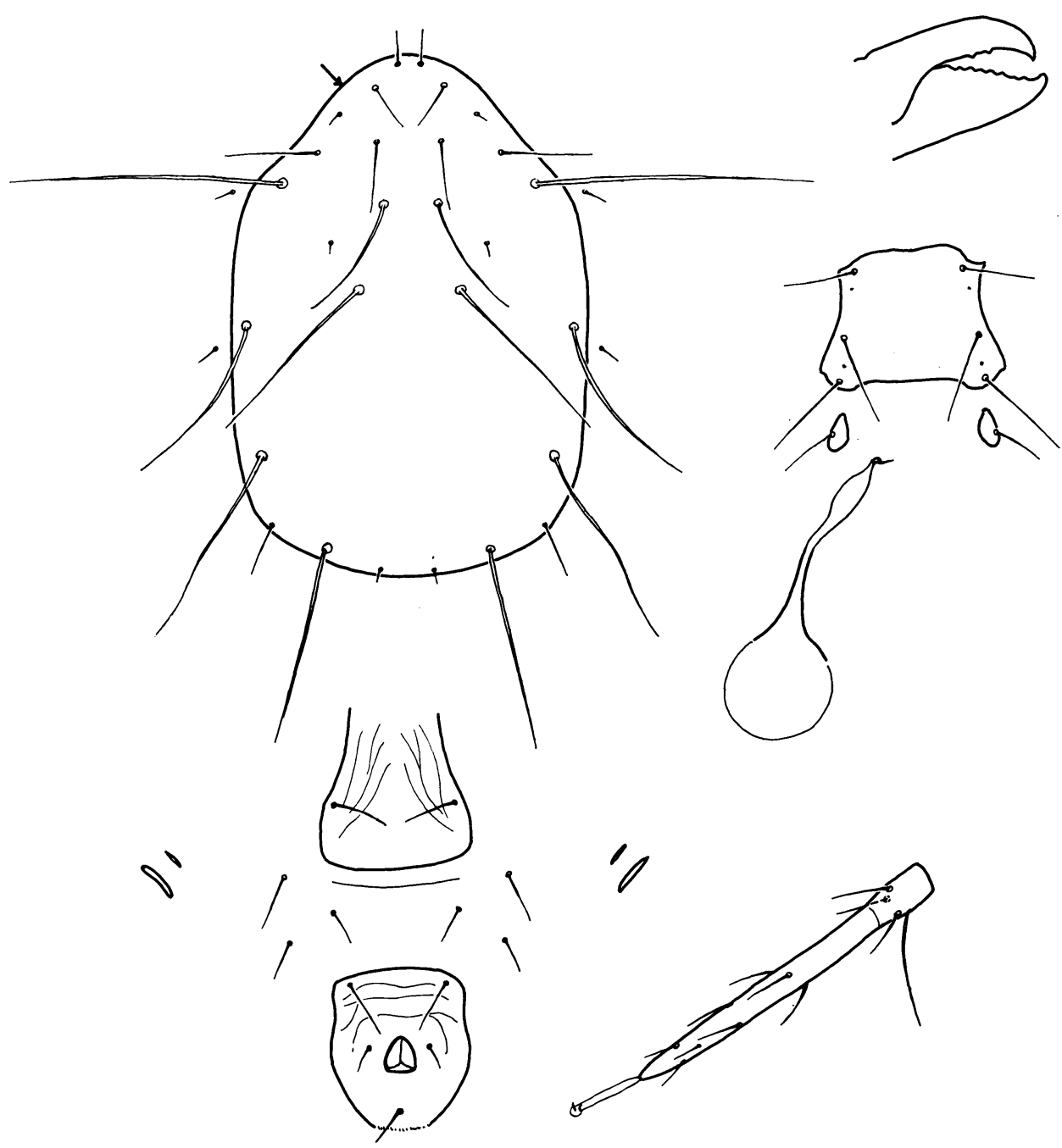

Fig. 53. Phytoseiulus macropilis (Banks).

anal plate $67 \mu$ wide, $105 \mu$ long, with three pairs of preanal setae. Primary metapodal platelets $25 \mu$ long. Genital plate $67 \mu$ wide. Sternal plate not delimited on observed specimens. Cervix of spermatheca $13 \mu$ long, the atrium expanded, forming a thin-walled chamber $13 \mu$ long. Leg IV with knobbed sensory seta on basitarsus, $37 \mu$.

Male. Unknown.

COLLECTION DATA

Sonoma Countr: 1 mile south of Trenton, September 3, 1957 (R. O. Schuster, L. M. Smith).

Found on grapevines.

\section{ACKNOWLEDGMENTS}

Many persons assisted in collecting and assembling specimens, throughout the preparation of this paper. For the loan of types or identified specimens we are grateful to Edward W. Baker, Donald A. Chant, Donald De Leon, Gudo Dosse, Charles E. Kennett, Martin H. Muma, and Fred S. Truxal. Mme. C. Athias- 
Henriot compared California specimens with species from her collection on numerous occasions. We thank the individual collectors, also, as their efforts added a number of the species represented. Especially we thank Franklin C. Raney for determining plants represented in the litter samples.
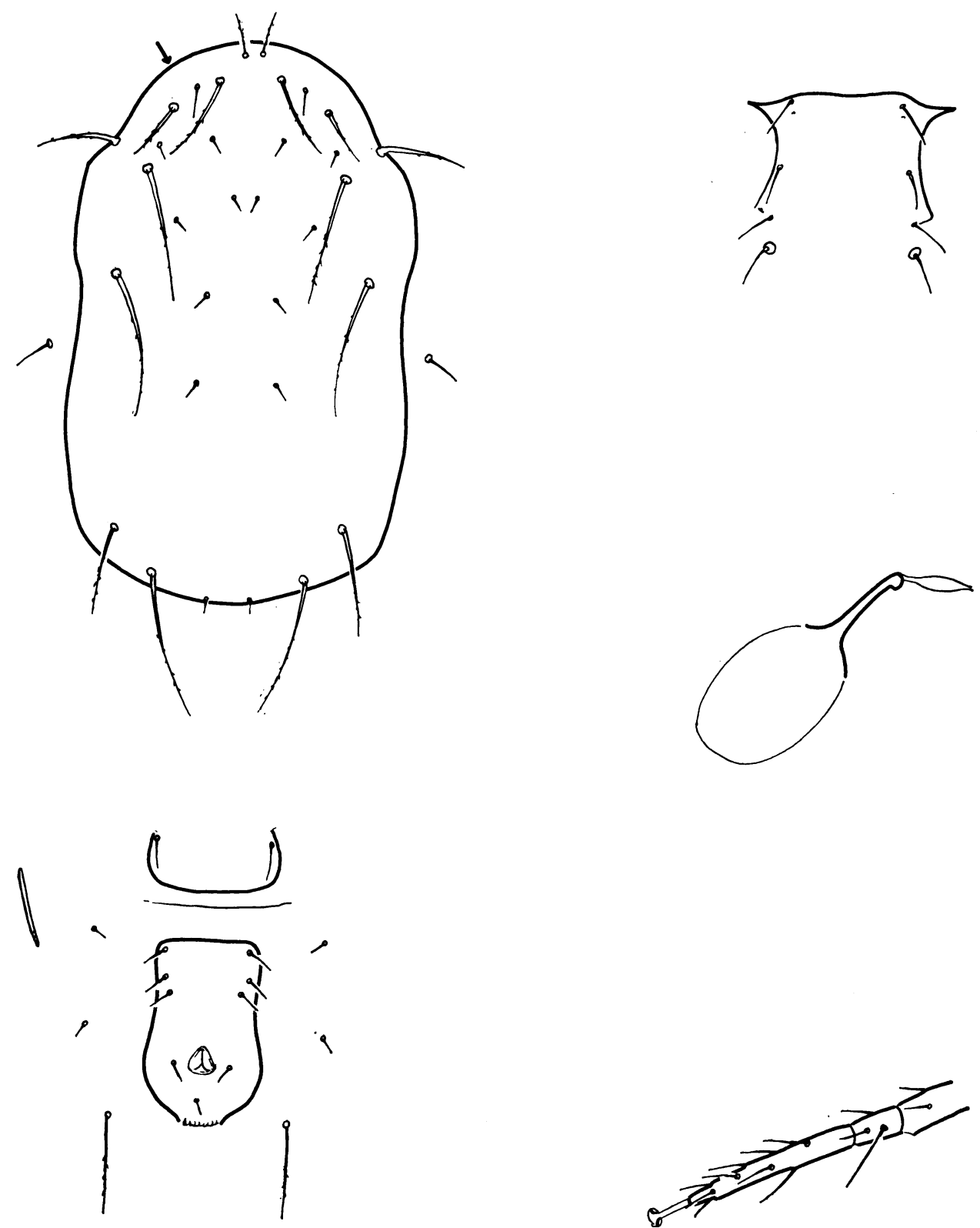

Fig. 54. Pennaseius finitimus (Ribaga). 


\section{LITERATURE CITED}

Athias-HenRiot, C.

1957. Phytoseiidae et Aceosejidae (Acarina, Gamasina) d'Algérie. I. Genres Blattisocius Keegan, Iphiseius Berlese, Amblyseius Berlese, Phytoseius Ribaga, Phytoseiulus Evans. Bul. Soc. d'Hist. Nat. de l'Afrique du Nord 48:319-52.

1958. Phytoseiidae et Aceosejidae (Acarina, Gamasina) d' Algérie. II. Phytoseiidae: clé des genres, genres Amblyseius Berlese (suite) et Seiulus Berlese. Bul. Soc. d'Hist. Nat. de l'Afrique du Nord 49:23-43.

1959. Acariens planticoles d'Algérie. I. $5^{\mathrm{e}}$ contribution au genre Amblyseius Berlese (Phytoseiidae). II. Première liste d' Actinochitinosi (Cheyletidae, Caligonellidae, Hemisarcoptidae). Bul. de Cl. des Sci., Acad. Roy. de Belgique, Brussels (Sér. 5) 45:130-53.

1961. Mésostigmates (Urop. excl.) Édaphiques Méditerranéens (Acaromorpha, Anactinotrichida). Acarologia 3:381-509.

[1962.] Phytoseiidae et Aceosejidae (Acarina, Gamasina) d'Algérie. IV. Genre Typhlodromus Scheuten, 1857. Bul. Soc. d'Hist. Nat. de l'Afrique du Nord (1960) 51:62-107.

BAKER, EdWARD W., and G. W. WharToN

1952. An introduction to acarology. The Macmillan Company, New York. 465 pp.

BANKS, NATHAN

1905. Descriptions of some new mites. Proc. Ent. Soc. Washington 7:133-42.

1915. The Acarina or mites. U. S. Dept. Agr. Rpt. 108. 153 pp.

Berlese, Antonio

1914. Acari nuovi. Redia 10:113-50.

1916. Centuria prima di Acari nuovi. Redia 12:19-67.

1923. Centuria sesta di Acari nuovi. Redia 15:237-62.

Buchelos, T. C., and A. Earl Pritchard

1960. Amblyseius similoides, a new predacious mite from California (Acarina: Phytoseiidae). Pan-Pacific Ent. 36:179-82.

Chant, D. A.

1957a. Descriptions of some phytoseiide [sic] mites (Acarina: Phytoseiidae). Part 1. Nine new species from British Columbia with keys to the species of British Columbia. Part II. Redescriptions of eight species described by Berlese. Canad. Ent. 89:289-308.

$1957 b$. Note on the status of some genera in the family Phytoseiidae (Acarina). Canad. Ent. 89:528-32.

[1960a.] Phytoseiid mites (Acarina: Phytoseiidae). Part I. Bionomics of seven species in southeastern England. Part II. A taxonomic review of the family Phytoseiidae, with descriptions of 38 new species. Canad. Ent. 91 (1959, sup. 12). 166 pp.

$1960 b$. Two new species of Typhlodromus from California (Acarina: Phytoseiidae). PanPacific Ent. 36:135-38.

Cunliffe, Frederick, and EdWARd W. BAKER

1953. A guide to the predatory phytoseiid mites of the United States. Pinellas Biol. Lab. Pub. $1.28 \mathrm{pp}$.

DE LeON, DONALD

1959a. A new genus and three new species of phytoseiid mites from Mexico with collection records on Phytoseius plumifer (C. \& F.) and P. macropilis (Banks). Ent. News 70:147-52.

1959b. Two new genera of phytoseiid mites with a note on Proprioseius meridionalis Chant (Acarina: Phytoseiidae). Ent. News 70:257-62.

1959c. Seven new Typhlodromus from Mexico with collection notes on three other species (Acarina: Phytoseiidae). Florida Ent. 42:113-21.

Dosse, Gudo

1957. Morphologie und Biologie von Typhlodromus zwölferi n. sp. (Acar., Phytoseiidae). Ztschr. Angew. Ent. 41:301-11.

1959. Über den Kopulationsvorgang bie Raubmilben aus der Gattung Typhlodromus (Acar., Phytoseiidae). Pflanzenschutzber. 22:125-33.

Evans, G. OWEN

1952a. On a new predatory mite of economic importance. Bul. Ent. Res. 43:397-401.

1952b. A new typhlodromid mite predacious on Tetranychus bimaculatus Harvey in Indonesia. Ann. and Mag. Nat. Hist. (ser. 12) 5:413-16.

Garman, Philip

1948. Mite species from apple trees in Connecticut. Connecticut (State) Agr. Expt. Sta. Bul. $520.27 \mathrm{pp}$.

1958. New species belonging to the genera Amblyseius and Amblyseiopsis with keys to Amblyseius, Amblyseiopsis, and Phytoseiulus. Ann. Ent. Soc. Amer. 51:69-79. 
Garman, Philip, and E. A. McGregor

1956. Four new predaceous mites (Acarina: Phytoseiidae). Bul. Southern California Acad. Sci. 55:7-13.

Huffaker, C. B., and C. E. KennetT

1956. Experimental studies on predation: Predation and cyclamen-mite populations on strawberries in California. Hilgardia 26 (4) :191-222.

Hughes, A. M.

1948. The mites associated with stored food products. Min. Agr. and Fisheries, London. $168 \mathrm{pp}$.

KARG, WOLFGANG

1961. Zur Kenntnis der Typhlodromiden (Acarina: Parasitiformes) aus Acker- und Grünlandböden. Ztschr. Angew. Ent. 47:440-52.

KenNeTt, C. E.

1958. Some predacious mites of the subfamilies Phytoseiinae and Aceosejinae (Acarina: Phytoseiidae, Aceosejidae) from central California with descriptions of new species. Ann. Ent. Soc. Amer. 51:471-79.

MACGILL, Elsie I.

1939. A gamasid mite (Typhlodromus thripsi n. sp.), a predator of Thrips tabaci Lind. Ann. Appl. Biol. 26:309-17.

MCGREGOR, E. A.

1954. Two new mites in the genus Typhlodromus (Acarina: Phytoseiidae). Bul. Southern California Acad. Sci. 53:89-92.

1956. The mites of citrus trees in southern California. Mem. Southern California Acad. Sci. 3:5-42.

Muma, Martin H.

1955. Phytoseiidae (Acarina) associated with citrus in Florida. Ann. Ent. Soc. Amer. 48: 262-72.

1961. Subfamilies, genera, and species of Phytoseiidae (Acarina: Mesostigmata). Florida State Mus. Bul. Biol. Sci. 5:267-302.

Nesbitt, H. H. J.

1951. A taxonomic study of the Phytoseinae (family Laelaptidae) predaceous upon Tetranychidae of economic importance. Zool. Verhandl. 12. $64 \mathrm{pp}$.

Newell, IRWIN M.

1955. An autosegregator for use in collecting soil-inhabiting arthropods. Trans. Amer. Microse. Soc. 74:389-92.

Oudemans, A. C.

1929. Acarologische Aanteekeningen XCIX. Ent. Ber. 8:11-20.

1930. Acarologische Aanteekeningen CII. Ent. Ber. 8:69-74.

Parrott, P. J., H. E. Hodgkiss, and W. J. Schoene

1906. The apple and pear mites. New York State Agr. Expt. Sta. Bul. 283:281-318.

Pritchard, A. EARL, and Edward W. BAKER

1962. Mites of the family Phytoseiidae from central Africa, with remarks on the genera of the world. Hilgardia. $33(7): 205-309$.

Ribaga, Constantino

1902. Gamasidi planticoli. Riv. di Patol. Veg. 10:175-78.

Scheuten, A.

1857. Einiges über Milben. Arch. f. Naturgesch. 23:104-12.

SCHUSTER, ROBERT O.

1957. A new species of Typhlodromus from California (Phytoseiidae: Acarina). Pan Pacific Ent. 33:203-05.

1959. A new species of Typhlodromus near T. bakeri (Garman) and a consideration of the occurrence of T. rhenanus (Oud.) in California (Acarina: Phytoseiidae). Proc. Ent. Soc. Washington 61:88-90.

Smith, Leslie M., and Francis M. Summers

1949. The structure and biology of the red spider predator "Hypoaspis" macropilis (Banks) (Acarina, Laelaptidae). Proc. Ent. Soc. Washington 51:209-18.

VitzThum, H. GRAF

1941. Acarina. In H. G. Bronns [ed.], Klassen und Ordnungen des Tierreichs. 5 (Abt. IV, Buch 5). $1011 \mathrm{pp}$.

Wainstein, B. A.

1962. Révision du genre Typhlodromus Scheuten, 1857 et systématique de la famille des Phytoseiidae (Berlese, 1916) (Acarina: Parasitiformes). Acarologia 4:5-30.

WOMERSLEY, H.

1954. Species of the subfamily Phytoseiinae (Acarina: Laelaptidae) from Australia. Australian Jour. Zool. 2:169-91. 


\section{APPENDIX}

The diagrams in figure 55 illustrate the structure of a 16-inch-square Berlese funnel with grid, as suggested by Newell (1955). The materials needed for its construction are listed on the following page.
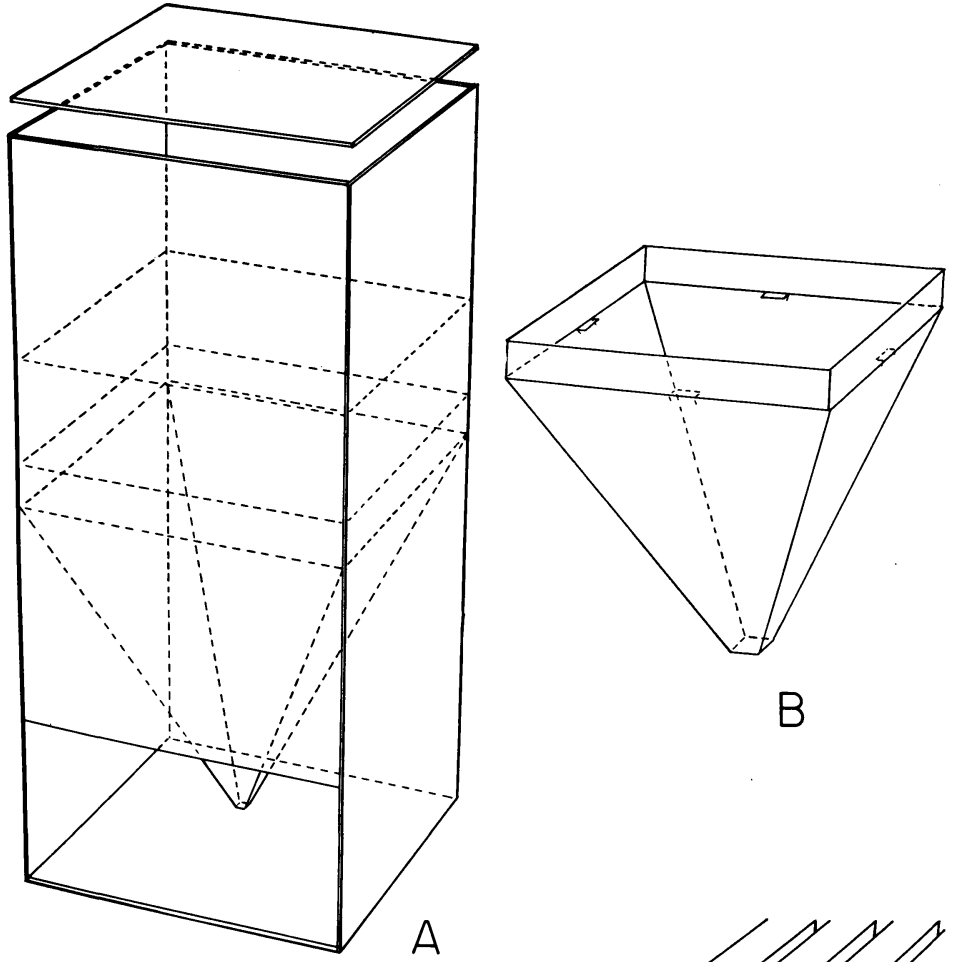

B
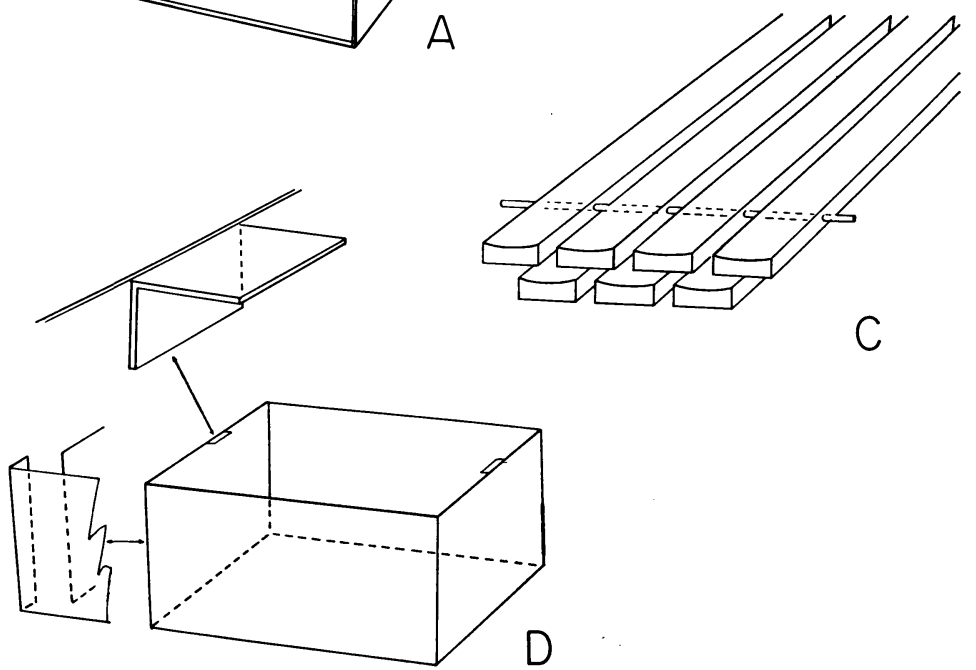

C

Fig. 55. Details of construction of Berlese-type funnel. A, position of funnel and hopper within plywood frame; B, funnel; C, grid; D, hopper. 


\section{WOOD}

Quarter-inch plywood

1 top, $16^{1 / 2^{\prime \prime} \times 16^{1} / 2^{\prime \prime}}$

2 sides, $161 / 2^{\prime \prime} \times 36^{\prime \prime}$

1 front, $16^{\prime \prime} \times 27^{\prime \prime}$

1 back, $16^{\prime \prime} \times 36^{\prime \prime}$

Half-inch plywood

1 bottom, $16^{\prime \prime} \times 16^{\prime \prime}$

Half-inch pine

21 strips, $3 / 4^{\prime \prime} \times 13^{\prime \prime}$

Sheet Metal

4 hopper sides $16^{\prime \prime} \times 7^{\prime \prime}$

4 funnel sides $161 / 2^{\prime \prime} \times 18^{\prime \prime}$

2 hopper grips $3^{\prime \prime} \times 3^{\prime \prime}$, bent to $3^{\prime \prime} \times 11 / 2^{\prime \prime}$

4 hopper rests $21 / 2^{\prime \prime} \times 1^{\prime \prime}$, bent to $21 / 2^{\prime \prime} \times 1 / 2^{\prime \prime}$

1 hardware-cloth hopper bottom $161 / 2^{\prime \prime} \times 161 / 2^{\prime \prime}$

\section{HARDWARE}

4 lengths of welding rod $13^{\prime \prime}$ long

2 strap hinges

8 rivets or bolts

1 electric fixture: wire, socket, and 100-watt heat source

Glue and nail together the sides and bottom of the plywood frame. The front panel is open below, to allow manipulation of the specimen bottles. Bend the funnel sides below a 2 " collar, and taper them to approximately $1 \frac{1}{2} 2^{\prime \prime}$, to give a lower opening $1^{\prime \prime}$ square. Solder the hopper rests at base of collar, grips at top of hopper. Along one edge of each funnel and hopper side, bend $1 / 2$ " of the sheet metal at right angles and solder to the adjacent piece. Bend $1 / 2$ " of hardware cloth over base of hopper all around, and solder. Bolt or rivet the funnel in the plywood frame. In the top, drill a hole for the electric fixture and several small ventholes to relieve condensation. Attach top to frame with hinges.

Drill a hole of a diameter smaller than that of the welding rod near each end of each wooden strip and position the strips on the rods. Eleven strips form the upper layer and ten strips form the lower layer. Position the two layers $1 / 4$ " apart, in any convenient manner. The grid rests in the tapered part of the funnel, below the hopper. 

The journal HILGARDIA is published at irregular intervals, in volumes of about 650 to 700 pages. The number of issues per volume varies.

Single copies of any issue may be obtained free, as long as the supply lasts; please request by volume and issue number from:

$$
\begin{aligned}
& \text { Agricultural Publications } \\
& \text { University Hall } \\
& \text { University of California } \\
& \text { Berkeley 4, California }
\end{aligned}
$$

The limit to nonresidents of California is 10 separate titles. The limit to California residents is 20 separate titles.

The journal will be sent regularly to libraries, schools, or institutions in one of the following ways:

1. In exchange for similar published material on research.

2. As a gift to qualified repository libraries only.

3. On a subscription basis $-\$ 7.50$ a year paid in advance. All subscriptions will be started with the first number issued during a calendar year. Subseribers starting during any given year will be sent back numbers to the first of that year and will be billed for the ensuing year the following January. Make checks or money orders payable to The Regents of The University of California; send payment with order to Agricultural Publications at above address. 